Universidade de São Paulo

Escola Superior de Agricultura "Luiz de Queiroz"

N-Acetilcisteína em estudos de transmissão de Xylella fastidiosa por cigarrinhas

Karla Kudlawiec

Dissertação apresentada para obtenção do título de Mestra em Ciências. Área de concentração: Entomologia 


\section{Karla Kudlawiec}

Engenheira Agrônoma

N - Acetilcisteína em estudos de transmissão de Xylella fastidiosa por cigarrinhas versão revisada de acordo com a resolução CoPGr 6018 de 2011

\section{Orientador: \\ Prof. Dr. JOÃO ROBERTO SPOTTI LOPES}

Dissertação apresentada para obtenção do título de Mestra em Ciências. Área de concentração: Entomologia

\section{Piracicaba}


Dados Internacionais de Catalogação na Publicação DIVISÃO DE BIBLIOTECA - DIBD/ESALQ/USP

Kudlawiec. Karla

N-actilcisteína em estudos de transmissão de Xylella fastidiosa por cigarrinhas / Karla Kudlawiec - - versão revisa da de a cordo com a resolução CoPGr 6018 de 2011. - - Piracicaba, 2021.

$75 \mathrm{p}$.

Dissertação (Mestrado) - - USP / Escola Superior de Agricultura "Luiz de Queiroz".

1. Clorose variegada dos citros 2. Vetor 3. NAC 4. Controle I. Título 


\section{DEDICATÓRIA}

Dedico aos meus pais Bernardo e Ivone, pelo exemplo de amor e por serem meus maiores impulsionadores

Àquele que será sempre meu guia, avô Carlos. 


\section{AGRADECIMENTOS}

Agradeço a Deus por nortear meus caminhos...

Agradeço aos meus pais por todo apoio, amor e dedicação e a toda minha família que eu amo e admiro muito.

À minha irmã Carol por ser minha parceira de vida e por estar sempre ao meu lado em todos os momentos.

Ao professor João Roberto Spotti Lopes pela orientação e apoio nas decisões ao longo do mestrado.

Aos pesquisadores do IAC-Cordeirópolis, Alessandra Alves de Souza e Helvécio Dela-Coletta Filho pela ajuda com o projeto de pesquisa e pela orientação no desenvolvimento do projeto.

Ao Dr Alberto Fereres, que me recebeu em seu laboratório durante o estágio no exterior e as pesquisadoras Aranzazu Moreno e Elisa Garzo por toda ajuda. Estendo meu agradecimento à técnica María Plaza e ao pós - doutorando Daniele Cornara por todo auxilio.

Ao prof Dr. Walmes Zeviani - UFPR pela ajuda com as análises estatísticas.

Aos colegas e companheiros que tornaram meus 6 meses em Madri uma experiência enriquecedora profissional e pessoalmente. Alan, Marina, Clara, Elena, Carolina, Cristina, Pierpaolo e Ana, vocês são 10 ! Os echo mucho de menos!

Aos colegas do laboratório de insetos vetores, em especial a Maria Fernandae a Mariana pela ajuda no decorrer do experimentos.

Aos meus amigos, que mesmo com a distância levo comigo Mayara, Gaúcho, Marília, Bianca e Fernanda.

Aos colegas da pós-graduação com os quais compartilhei momentos de estudos, apoio e de descontração, em especial à Sabrina, Thais, Matheus e Fernando, que tornaram-se amigos do coração. Incluo aqui a amiga Kelly com quem compartilhei muitos momentos felizes nesta etapa final e a pessoa que foi fundamental para minha evolução pessoal.

Á Fundação de Amparo a Pesquisa do Estado de São Paulo por financiar o projeto no país (Proc: 2018/19980-9) e o estágio no exterior (Proc: 2019/13768-0).

A todos que de alguma forma cruzaram meu caminho durante esses anos em especial aos que fizeram parte da fase final deste importante processo... 
EPÍGRAFE

DON'T

QUIT. 


\section{SUMÁRIO}

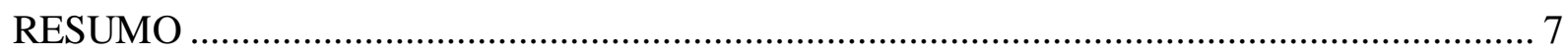

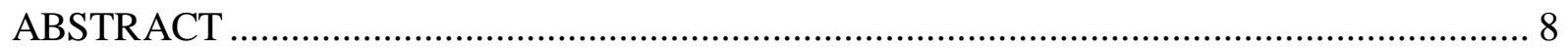

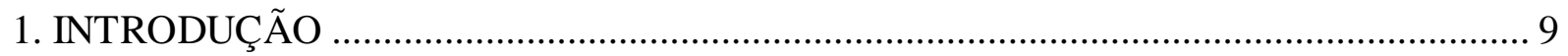

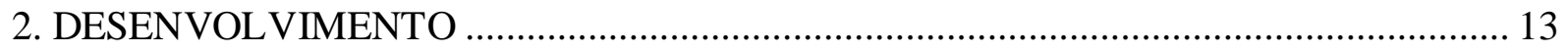

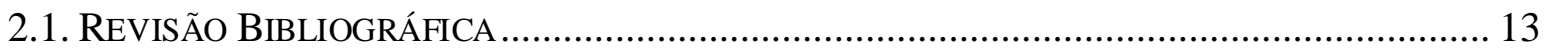

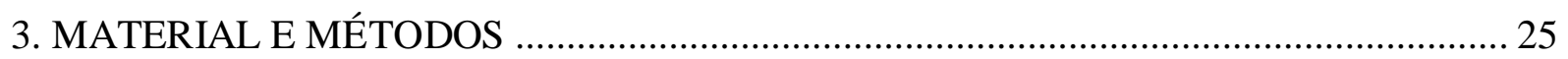

3.2. Detecção de $X$. fastidiosa em adultos de M. leucomelas e nas plantas-teste de C. roseus

3.3. Avaliação da eficiência de aquisição de $X$. fastidiosa em plantas-fonte tratadas ou não com NAC e de subsequente transmissão para plantas sadias............................................. 28 3.4. Avaliação do efeito do NAC na transmissão de $X$. fastidiosa após a aquisição da bactéria

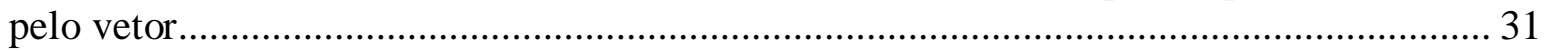

3.5. Avaliação da transmissão de $X$. fastidiosa para plantas-teste sadias, previamente tratadas

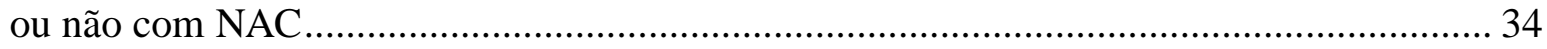

3.6. Comportamento alimentar de Philaenus spumarius em plantas de Sonchus oleraceus após tratamento com NAC em fertilizante húmico........................................................... 36 3.7. Estudo de EPG de Philaenus spumarius em S. oleraceus tratadas com NAC via solução

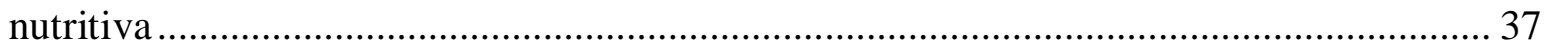

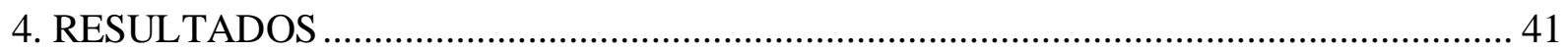

4.1. Avaliação da eficiência de aquisição de X. fastidiosa em plantas-fonte tratadas ou não com NAC e de subsequente transmissão para plantas sadias............................................... 41 4.2. Avaliação do efeito do NAC na transmissão de $X$. fastidiosa após a aquisição da bactéria pelo vetor.

4.3. Avaliação da transmissão de $X$. fastidiosa para plantas-teste sadias, previamente tratadas ou não com NAC

4.4. Comportamento alimentar de $P$. spumarius em plantas de $S$. oleraceus tratadas com NAC (formulação granulada com fertilizante húmico).... .48 4.5. Avaliação da absorção de solução nutritiva e comportamento alimentar de $P$. spumarius em plantas de $S$. oleraceus tratadas com NAC (formulação em pó com solução nutritiva) 55

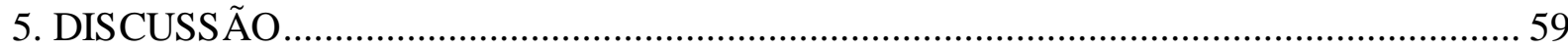

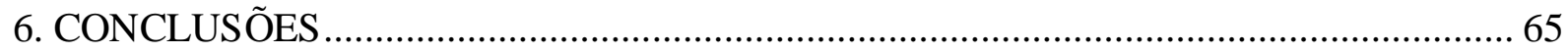

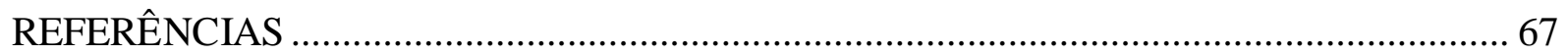

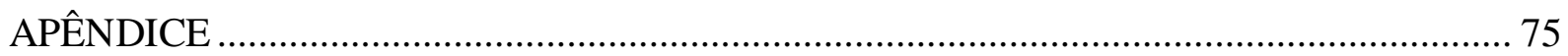




\section{RESUMO}

\section{N-acetilcisteína em estudos de transmissão de Xylella fastidiosa por cigarrinhas}

A clorose variegada dos citros (CVC), causada pela bactéria Xylella fastidiosa, é uma importante doença cuja incidência em pomares cítricos diminiu no Estado de São Paulo em resposta a táticas de controle preventivas, tais como erradicação de plantas doentes, plantio de mudas sadias certificadas e controle de insetos vetores, que são cigarrinhas da subfamília Cicadellinae (Hemiptera: Cicadellidae). Estudos recentes mostraram que o agente mucolítico $\mathrm{N}$-acetilcisteína (NAC), usado para tratamento de infecções bacterianas em sistema respiratório de humanos, tem potencial para controle de doenças bacterianas em plantas. Quando aplicado em plantas de Citrus sinensis (L) Osbeck com CVC, o NAC reduz a população bacteriana de $X$. fastidiosa e os sintomas da doença. Assim, postulou-se que esse mucolítico poderia afetar, também, a eficiência de transmissão de $X$. fastidiosa pelo inseto vetor. Os objetivos da presente pesquisa foram: a) avaliar a eficiência de aquisição de $X$. fastidiosa por cigarrinha em plantas com CVC tratadas ou não com NAC, e a subsequente transmissão para plantas-teste sadias; $b$ ) avaliar o efeito do NAC na transmissão após a aquisição da bactéria pelo vetor; c) avaliar a transmissão de $X$. fastidiosa para plantas-teste sadias, previamente tratadas ou não com NAC; d) avaliar o comportamento alimentar de um inseto vetor em plantas tratadas com NAC por meio da técnica de electrical penetration graph (EPG). A cigarrinha vetora Macugonalia leucomelas (Walker) foi usada nos experimentos de transmissão (a-c), que envolveram plantas tratadas com NAC ou não (controle). Para avaliar o efeito sobre a aquisição, NAC foi aplicado via fertilizante húmico $\left(3 \mathrm{~N}: 10 \mathrm{P}_{2} \mathrm{O}_{5}: 10 \mathrm{~K}_{2} \mathrm{O}\right)$, na proporção de $2 \mathrm{~g}$ para cada $1 \mathrm{Kg}$ do fertilizante, em plantas de $C$. sinensis infectadas por $X$. fastidiosa (plantas-fonte). Para avaliar o efeito após a aquisição, as cigarrinhas foram alimentadas em dieta artificial com suspensão de células de $X$. fastidiosa e posteriormente alimentadas por diferentes períodos $(24,72,120 \mathrm{~h})$ em seedlings sadios de $C$. sinensis tratados com solução nutritiva contendo NAC. Em um terceiro experimento avaliou-se a transmissão para plantas sadias de Catharanthus roseus (planta-teste) previamente tratadas com o fertilizante húmico contendo NAC. Os resultados mostraram que as eficiências de aquisição e de subsequente transmissão de $X$. fastidiosa por M. leucomelas não foram afetadas pelo tratamento de plantas-fonte da bactéria com NAC por um período de 90 dias. Após a aquisição de $X$. fastidiosa, a exposição por até 120 h do inseto vetor a plantas cítricas sadias tratadas com NAC não afeta a taxa de insetos positivos para a bactéria ou a probabilidade de transmissão para plantas-teste. O pré-tratamento de plantas sadias de C. roseus com NAC por 30 dias não impede a sua infecção por $X$. fastidiosa após a inoculação pelo inseto vetor. Finalmente, verificou-se que a aplicação do NAC em plantas de Sonchus oleraceus não altera o comportamento alimentar do vetor Philaenus spumarius (Hemiptera: Aphrophoridae), não influenciando em variáveis de EPG relacionadas à transmissão de $X$. fastidiosa. Assim o NAC, nas condições aqui testadas, não afetou a aquisição e transmissão de $X$. fastidiosa por $M$. leucomelas bem como não alterou o comportamento alimentar de $P$. spumarius.

Palavras-chave: Clorose variegada dos citros, Vetor, NAC, Controle 


\section{ABSTRACT \\ $\mathrm{N}$-acetylcysteine in transmission studies of Xylella fastidiosa by sharpshooters}

Citrus variegated chlorosis (CVC), caused by the Xylella fastidiosa bacterium, is an important disease which incidence has decreased in citrus orchards in the State of São Paulo. The incidence reduction is related to the preventive control tactics used, such as eradication of diseased plants, planting of certified healthy seedlings and the chemical control of the insect vector, which are leafhoppers belonging to the subfamily Cicadellinae (Hemiptera: Cicadellidae). Recent studies have shown that the mucolytic agent $\mathrm{N}$-acetylcysteine (NAC), used to treat human respiratory bacterial infections, has the potential to control bacterial diseases in plants. When applied to Citrus sinensis (L) Osbeck plants with CVC, NAC reduced the $X$. fastidiosa bacterial population and the disease symptoms. Thus, it was postulated that this mucolytic could also affect the transmission efficiency of $X$. fastidios $a$ by the insect vectors. That said, the objectives of this research were: a) to evaluate the X. fastidiosa acquisition efficiency by leafhopper in CVC plants treated and nontreated with NAC, and the subsequent transmission to healthy test plants; b) to evaluate the NAC effect on bacteria transmission after acquired by the vector; c) to evaluate the $X$. fastidiosa transmission to healthy test plants, previously treated or nontreated with NAC and; d) to evaluate the insect vector feeding behavior in NAC treated and nontreated plants, using the electrical penetration graph (EPG) technique. The leafhopper Macugonalia leucomelas (Walker) was used in the transmission experiments (a-c), which involved NAC treated and nontreated (control) plants. To assess the effect on acquisition, NAC was applied via humic fertilizer $\left(3 \mathrm{~N}: 10 \mathrm{P}_{2} \mathrm{O}_{5}: 10 \mathrm{~K}_{2} \mathrm{O}\right)$ (proportion: $2 \mathrm{~g}$ for each $1 \mathrm{~kg}$ of fertilizer) in $C$. sinensis plants infected by $X$. fastidiosa (source plants). To evaluate the effect after acquisition, leafhoppers were fed in an artificial diet mixed with $X$. fastidiosa cells after fed for different periods $(24,72,120 \mathrm{~h})$ in $C$. sinensis healthy seedlings treated with NAC in a nutritive solution. In a third experiment, transmission to Catharanthus roseus (test plant) healthy plants, previously treated with humic fertilizer containing NAC was evaluated. The results showed that the efficiencies of $X$. fastidios $a$ acquisition and following transmission by the M. leucomelas were not affected by the NAC treatment in a source bacterium plants for 90 days. After $X$. fastidiosa acquisition, vector exposure for up to $120 \mathrm{~h}$ in a healthy citrus plants NAC treated does not influence the positive bacterium insect rates or transmission probability to test plants. The pretreatment with NAC in healthy $C$. roseus plants for 30 days did not prevent their infection by $X$. fastidiosa after inoculation by the insect vector. Finally, it was verified that the NAC application in Sonchus oleraceus plants does not alter the Philaenus spumarius (Hemiptera: Aphrophoridae) feeding behavior, does not influencing EPG variables related to the $X$. fastidiosa transmission. Thus NAC under conditions tested here, did not affect $X$. fastidiosa acquisition and transmission by M. leucomelas and did not change the P.spumarius feeding behavior.

Keywords: Citrus variegated chlorosis, Vector, NAC, Control 


\section{INTRODUÇÃO}

A citricultura ocupa posição de destaque no cenário do agronegócio brasileiro, (Secex 2020) sendo o maior produtor mundial de laranja e o maior exportador de suco, representando cerca de 80\% do mercado mundial da fruta (Fundecitrus 2019; Usda 2020). Na safra 2019/2020 foram colhidas 386,79 milhões de caixas da fruta in natura $(40,8 \mathrm{~kg})$. Deste total, a parcela da produção processada rendeu mais de 1 milhão de toneladas de suco para exportação, gerando uma receita de US\$1,751 bilhão ao setor (Secex 2020).

Apesar de altas produtividades e grandes avanços tecnológicos, a cadeia citrícola sempre sofreu com entraves fitossanitários, historicamente relatados. Uma das doenças mais importantes da citricultura é a clorose variegada dos citros (CVC), que ocasionou prejuízos expressivos a partir de sua descoberta no norte do Estado de São Paulo e sul do Triângulo Mineiro, em 1987 (Coletta-Filho et al. 2020). Embora a sua incidência seja baixa no levantamento de 2019 (1,7\% de plantas doentes), durante os anos 2000 chegou a afetar 43\% das árvores de laranja-doce do parque citrícola paulista, causando prejuízos anuais estimados em 100 milhões de dólares (Bové \& Ayres 2007; Fundecitrus 2019). O agente causal da CVC é a bactéria Xylella fastidiosa, um fitopatógeno com grande variabilidade genética e que também é responsável por causar doenças em outras plantas cultivadas como videira, café, ameixa e oliveira (Mansfield et al. 2012; Saponari et al. 2014; Coletta-Filho et al. 2020). A ampla gama de espécies colonizadas e a comprovação de novos hospedeiros, categorizou $X$. fastidiosa como reemergente e, portanto, sua inclusão na lista de patógenos quarentenários da European and Mediterranean Plant Protection Organization (EPPO) A2 list (disponível online - versão 2019-09).

O mecanismo de patogenicidade da bactéria nas plantas é atribuído à sua capacidade de movimentação e colonização do xilema das plantas hospedeiras (de Souza et al. 2003; Niza et al. 2015). Mediado pela expressão gênica, o processo de colonização envolve a comunicação entre as bactérias (quorum sensing) que, de acordo com a densidade populacional, sinalizam para movimentação dentro do hospedeiro ou para produção de proteínas de adesão e da matriz de polissacarídeos, fundamentais no processo de formação do biofilme (Chatterjee et al. 2008; Ionescu et al. 2014). A estrutura formada obstrui os vasos do xilema da planta hospedeira, bloqueando o sistema vascular, impedindo fluxo de seiva e o transporte de nutrientes (Newman et al. 2003; de Souza et al. 2005).

A transmissão da bactéria ocorre, entre plantas, por meio de insetos vetores, que são cigarrinhas pertencentes principalmente à subfamília Cicadellinae (Hemiptera: Cicadellidae) 
(Roberto et al. 1996; Redak et al. 2004). O processo de transmissão envolve a aquisição em plantas infectadas com a bactéria, retenção desta pelo vetor e inoculação em plantas sadias (Backus et al. 2015). Na etapa de retenção no vetor, assim como em plantas hospedeiras, há formação do biofilme, importante para possibilitar a sobrevivênci a e multiplicação da bactéria em um ambiente turbulento como o estomodeu do inseto (Purcell et al. 1979; Killiny \& Almeida 2009b). As etapas envolvidas no processo de transmissão da bactéria podem ser influenciadas por diversos fatores, tais como título bacteriano presente na planta hospedeira, período e local de alimentação, espécie do inseto vetor, dentre outros (Purcell \& Finlay 1979; Hill \& Purcell 1997; Almeida \& Purcell 2006).

As perdas decorrentes da colonização da bactéria em plantas de laranja-doce, Citrus sinensis (L.) Osbeck, podem provocar decréscimos de até $90 \%$ na produção de frutos, e significativa redução na qualidade dos mesmos em todos os cultivares, uma vez que todas laranjas-doce são consideradas suscetíveis (Machado et al. 1994; Laranjeira \& Pompeu Jr. 2002). O manejo da CVC envolve medidas de exclusão, para evitar a entrada do patógeno na área de produção, de erradicação de plantas doentes e de controle das cigarrinhas vetoras, para reduzir fontes de inóculo da bactéria e sua disseminação em pomares (Lopes \& Krugner 2016). A adoção dessas práticas preventivas de infecção elevam os custos de produção e reduzem a margem de lucro da cultura (Coletta Filho \& De Souza 2014). Nesse contexto, as pesquisas sobre métodos alternativos que possam ser usados no controle preventivo ou curativo de infecções das plantas, ganham importância.

Os estudos que propõem inovações no controle dos patógenos podem partir de observações e comparação com outros microrganismos, os quais colonizam diferentes hospedeiros. Como exemplo, as bactérias Pseudomonas aeruginosa e Klebsiella pneumoniae, conhecidamente agentes causais de doenças em seres humanos, formam biofilme no decorrer no processo infeccioso, assim como o processo de colonização de $X$. fastidiosa em plantas. Para o tratamento dessas infecções no sistema respiratório, desde a década de 60 é utilizado um derivado do aminoácido natural L-cisteína, a N-Acetilcisteína (NAC) (Blasi et al. 2016; Aldini et al. 2018). A ação mucolítica desta molécula foi comprovada por meio de vários estudos que demonstraram a redução da produção de exopolissacarídeos e desagregação das bactérias que formam o biofilme.

Extrapolando as pesquisas da área médica para a agricultura, e aplicando os conhecimentos do uso do NAC no controle de doenças bacterianas, iniciaram-se as pesquisas com os patógenos de plantas. O efeito mucolítico foi avaliado na bactéria causadora do cancro cítrico, Xanthomonas citri, e mostrou redução da motilidade da bactéria na planta e diminuição 
na formação do biofilme e na produção de exopolissacarídeos. No estudo conduzido com $X$. fastidiosa houve redução da população bacteriana em plantas de laranja-doce (Muranaka et al. 2013). A proposta de uso da molécula do NAC na agricultura também está relacionada ao seu efeito antioxidante, o que favorece o desenvolvimento das plantas (Patente (11) PI 1101176-9 B1) (de Souza et al. 2018). Além disso, a molécula anti-bacteriana é de fácil aplicação, podendo ser associada à outras moléculas para potencializar sua ação, e devido ao seu tamanho pequeno pode ser facilmente absorvida pela planta. Não há relatos de resistência das bactérias à molécula, que é de fácil degradação, sem relatos de impactos ambientais negativos (Muranaka et al. 2013) .

Considerando-se que há diminuição da adesão e/ou crescimento bacteriano (formação de biofilme) de $X$. fastidiosa em plantas tratadas com NAC, postulou-se que esse mucolítico poderia afetar, também, a eficiência de transmissão da bactéria pelo inseto vetor. Sendo assim os objetivos dessa pesquisa foram: a) avaliar a eficiência de aquisição de $X$. fastidiosa por cigarrinhas em plantas com CVC tratadas ou não com NAC, e a subsequente transmissão para plantas-teste sadias; b) avaliar o efeito do NAC na transmissão de $X$. fastidios $a$ após a aquisição da bactéria pelo vetor; c) avaliar a transmissão de $X$. fastidiosa para plantas-teste sadias, previamente tratadas ou não com NAC; d) avaliar o comportamento alimentar de um inseto vetor em plantas tratadas com NAC por meio da técnica de electrical penetration graph (EPG), principalmente as atividades estiletares relacionadas à transmissão da bactéria $X$. fastidiosa . 


\section{DESENVOLVIMENTO}

\subsection{Revisão Bibliográfica}

\subsubsection{Produção citrícola no Brasil}

O Brasil é o maior produtor mundial de cítricos, com pomares ocupando 395.671 hectares do território nacional (Usda 2020; Fundecitrus, 2020). Deste total, 80\% das áreas produtoras estão localizadas no Estado de São Paulo e Triângulo e Sudoeste Mineiro e a grande maioria, cerca de 86,22 \%, é destinada a produção de laranja (Fundecitrus - PES 2018/2019). O volume de produção torna o país responsável pelo suprimento de mais de $80 \%$ do suco de laranja consumido mundialmente, consolidando-se como o mais importante fornecedor global deste produto (USDA 2020). Os países da Europa são os principais importadores, seguidos dos Estados Unidos e Japão (citrusBR-2019).Em 2019/2020 foram processados e exportados mais de 1 milhão de toneladas de suco, gerando uma receita de US\$ 1,751 bilhão ao setor (Secex, 2020).

O suco de laranja concentrado congelado (Frozen Concentrated Orange Juice - FCOJ; equivalente a $66^{\circ}$ Brix) e não congelado (Non Frozen Concentrated- NFC) é uma commodity considerada de alta volatilidade, isto porque a produtividade pode sofrer até $40 \%$ de variação em anos consecutivos, reflexo direto das condições climáticas e fitossanitárias da produção. Embora o Brasil ocupe posição de destaque entre os grandes produtores, a produção citrícola, historicamente, sofre com problemas fitossanitários (Neves et al. 2010). Apesar de atualmente o Huanglongbing (HLB) ou Greening ser considerado a principal doença da cultura, outras enfermidades como a clorose variegada dos citros (CVC), causada pela bactéria Xylella fastidiosa subsp. pauca também compõem a lista de entraves fitotécnicos a ser vencidas pelos citricultores.

\subsubsection{Bactéria Xylella fastidiosa e a clorose variegada dos citros (CVC)}

X. fastidiosa (Xanthomonadales: Xanthomonadaceae) é uma bactéria gram negativa, aeróbica, sem flagelos, com formato de pequenos bastonetes, $(0,3-0,5 \mu \mathrm{m}$ de diâmetro e 1-5 $\mu \mathrm{m}$ de comprimento) apresentando melhor crescimento em meios de cultura quando em temperatura entre $26^{\circ}-28^{\circ} \mathrm{C}$ e pH entre $6,5-6,9$. (Wells et al. 1987). A bactéria fitopatogênica 
é limitada aos vasos do xilema das plantas e apresenta distribuição desuniforme nos vasos que coloniza (Daugherty et al. 2010).

Existem mais de 500 espécies relatadas como hospedeiras de $X$. fastidiosa que, em sua grande maioria são assintomáticas, mesmo decorrido longo período após a inoculação (EFSA, 2019/2020). A importância da bactéria esta relacionada a sua capacidade de causar doenças em plantas de cultivo comercial, tais como: o mal de Pierce em videira (Pierce's disease- PD) (Hopkins \& Purcell 2002), a Atrofia dos Ramos do Cafeeiro (ARC) (De Lima et al. 1998), Escaldadura das Folhas da Ameixeira (Plum leaf scorch -PLS) (French \& Kitajima 1978) e a Síndrome do Declínio Rápido da Oliveira (Olive quick decline syndrome-OQDS) (Saponari et al. 2014).

A grande variabilidade genética e fenotípica da X. fastidiosa e a especificidade das estirpes com seus hospedeiros permitiu a divisão do fitopatógeno em três grupos monofiléticos maiores: X. fastidiosa subsp. fastidiosa; X. fastidiosa subsp. multiplex; X. fastidiosa subsp. pauca (Coletta-Filho et al. 2020). No Brasil, X. fastidiosa subsp. pauca tem maior destaque por causar a CVC, popularmente conhecida como amarelinho. O primeiro relato da doença no país ocorreu em 1987 no município de Colina, São Paulo. Na década de 1990, a bactéria podia ser encontrada em quase todas as áreas citrícolas do país e em 2005, com 43\% das laranjeiras infectadas, a doença atingiu seu ápice. Os prejuízos da cadeia citrícola, considerando apenas as reduções em produtividade atribuídos à CVC, foram da ordem de US\$ 121,8 milhões ao (Bové \& Ayres 2007).

O mecanismo de patogenicidade da bactéria na planta é atribuído à sua capacidade de movimentação e colonização (Simpson et al. 2000; de Souza et al. 2005; Mansfield et al. 2012). No processo de colonização, as bactérias comunicam-se entre si através do mecanismo de quorum sensing (QS) e, a partir dessa interação e da densidade populacional, regulam a expressão de genes de virulência. Os genes do cluster rpf (regulations of pathogenicity factors) regulam a produção de moléculas de ácidos graxo (diffusible signaling fator - $d s f$ ) que são fundamentais no processo de colonização. Quando ocorre a inoculação na planta, há diminuição da produção de $d s f$ e, essa sinalização proporciona a formação de vesículas da membrana externa que conferem um efeito teflon a bactéria, bloqueando a adesão nas paredes do xilema e permitindo maior movimentação ao longo dos vasos (Ionescu et al. 2014).

Quando os níveis populacionais da bactéria aumentam, há também acúmulo de $d s f$, que sinaliza então, outra etapa da colonização. Inicia-se a produção de proteínas de adesão, bem como da matriz de expolissacarídeos fundamentais na fomação do biofilme no hospedeiro (Lindow et al. 2014). O biofilme formado obstrui os vasos do xilema da planta hospedeira, 
bloqueando o sistema vascular, impedindo assim, o fluxo de seiva e o transporte de nutrientes na planta (de Souza et al. 2005; Mansfield et al. 2012).

Os primeiros sintomas reflexos decorrentes da colonização em plantas cítricas são pequenos pontos cloróticos na face adaxial de folhas maduras que correspondem a pequenos pontos na superfície abaxial. As árvores apresentam clorose internerval, semelhante a deficiência de zinco. Em plantas em desenvolvimento, há redução do crescimento e murcha dos galhos. Em árvores produtivas, devido à distribuição desuniforme de X. fastidiosa no hospedeiro, o dossel pode apresentar ramos sintomáticos ao lado de ramos assintomáticos. Com relação aos frutos, há perda de qualidade, com redução de até $75 \%$ do seu peso, endurecimento e amadurecimento precoce. Apesar de não causar a morte da planta, ocorrem decréscimos de até $90 \%$ da produção, principalmente nas cultivares consideradas suscetíveis como é o caso da 'Lima'. 'Pêra' e 'Rubi' (Machado et al. 1994).

\subsubsection{Transmissão de $X$. fastidiosa por insetos vetores}

Xylella fastidiosa é transmitida naturalmente entre plantas por insetos vetores (Roberto et al. 1996), mas também pode ser transmitida por enxertia com material propagativo contaminado, na produção de mudas cítricas. Acredita-se que a disseminação do patógeno a longas distâncias para diferentes regiões no Brasil tenha ocorrido principamente por meio do plantio de mudas infectadas (Roberto et al. 2002). As espécies potenciais vetoras de $X$. fastidiosa nas culturas hospedeiras nas Américas são majoritariamente cicadelídeos da subfamília Cicadellinae (Hemiptera: Membracoidea: Cicadellidae). Há espécies de Aphrophoridae e Clastopteridae (Hemiptera: Cercopoidea) como P. spumarius e Clastoptera sp., também relatadas como vetores de $X$. fastidiosa. As espécies pertencentes a esses grupos, conhecidas como cigarrinhas, alimentam-se de xilema e, em sua grande maioria, são polífagas. (Almeida et al. 2005).

Anatomicamente esses insetos possuem uma câmara de sucção conectada ao cibário, com musculatura bem desenvolvida, o que proporciona a sucção de líquidos sob forte pressão negativa (Redak et al. 2004). O mecanismo de transmissão compreende três etapas: aquisição em plantas portadoras da bactéria, retenção no inseto vetor e inoculação em plantas sadias (Backus et al. 2015).

$\mathrm{O}$ inseto adquire a bactéria durante a alimentação em plantas infectadas com $X$. fastidiosa. As cigarrinhas possuem aparelho bucal sugador, constituído de finos estiletes que penetram na planta e ao atingirem os vasos do xilema, succionam a seiva. Em plantas infectadas, 
as bactérias são succionadas juntamente com a seiva. No processo de retenção, a bactéria aderese as paredes do canal alimentar anterior do inseto (estomodeu), na região do pré cibário, formando o biofilme sob a camada de polissacarídeos, a qual é utilizada como fonte de carbono para nutrição da colôniaa ser formada. O processo de adesão é mediado por proteínas denominadas adesinas, situadas na membrana da bactéria que possibilitam sua ligação lateralmente à quitina, presente na cutícula do estomodeu do vetor e com isso ganham maior área de interação com a superfície e melhor aderência para suportar o fluxo de líquido durante a alimentação, que tem, em média, de $8 \mathrm{~cm} / \mathrm{s}$ de velocidade (Purcell et al. 1979; Killiny \& Almeida 2009b). Na etapa subsequente as células bacterianas iniciam a produção de exopolissacarídeos (EPS - extracellular polimeric substances) e à medida que a colônia cresce a tendência é que todas as células permaneçam polarmente ligadas entre si e à superfície do estomodeu e aptas então, a desprender-se e serem inoculadas (Purcell et al. 1979; Killiny \& Almeida 2009a). Insetos adultos que adquirem a bactéria estão aptos a transmitir ao longo da vida. As ninfas, por sua vez, perdem a capacidade infectiva na ecdise, isto porque o local de adesão das células bacterianas é revestido por tecido de origem ectodérmica que é trocado a cada processo de muda (Purcell \& Finlay 1979; Almeida et al. 2006).

A inoculação de $X$. fastidiosa em plantas pode ocorrer logo após a aquisição (Purcell \& Finlay 1979; Backus et al. 2009) e, poucas células bacterianas são suficientes para que a inoculação ocorra (Hill \& Purcell 1995a). O mecanismo 'salivação - ingestão - egestão' hipotetiza que durante a alimentação do vetor infectivo há ingestão do conteúdo xilemático e de parte do conteúdo enzimático, liberado durante a produção da bainha salivar. Nesse processo as enzimas e o meio turbulento produzido pela bomba pré-cibarial para sucção do líquido, podem provocar o descolamento de células de $X$. fastidiosa dentro do estomodeu. Essas células bacterianas podem então, serem inoculadas na egestão (expulsão dos fluídos presentes no canal alimentar) (Backus et al. 2009, 2012, 2015). Outros autores também propuseram a participação da válvula pré-cibarial no processo de inoculação (Purcell et al. 1979; Almeida et al. 2006). Novos estudos têm sustentado a hipótese de que a inoculação ocorre durante o processo de egestão dos fluídos, regulada pela bomba pré-cibarial, relacionando ainda, uma possível falta de estímulo à continuação da ingestão (Cornara et al. 2020).

A transmissão de $X$. fastidiosa por um vetor é influenciada pelas interações vetorhospedeiro-patógeno e ainda, por fatores ecológicos como abundância, mobilidade, plantas hospedeiras preferidas (Almeida et al. 2005). Na relação vetor-patógeno, a eficiência de aquisição da bactéria pelo inseto está correlacionada ao período de alimentação e a população bacteriana no tecido infectado, implicando em maiores taxas de aquisição com maiores períodos 
de alimetação e/ou maior população bacteriana (Purcell \& Finlay 1979; Hill \& Purcell 1997). O local de alimentação do inseto vetor no hospedeiro influencia a eficiência de aquisição de $X$. fastidiosa por esta apresentar distribuição desuniforme na planta. Em outras palavras, a eficiência de aquisição depende da escolha do vetor por alimentar-se em regiões da planta hospedeira com grande concentração bacteriana (Daugherty et al. 2010). Além disso, sabe-se que a população do patógeno sofre alterações ao longo do tempo e também afeta a eficiência de aquisição (Hill \& Purcell 1997). Os distintos hospedeiros de X. fastidiosa podem apresentar diferentes níveis de infecção e severidade dos sintomas, o que reflete na eficiência de aquisição do vetor, (Almeida \& Purcell 2003; Krivanek \& Walker 2005; Lopes et al. 2009), isto porque, insetos preferem alimentar-se em plantas ou em locais da planta que não apresentam sintomas severos de doença (Marucci et al. 2003; Del Cid et al. 2018).

Sabe-se que há pouca ou nenhuma especifidade quanto a transmissão de $X$. fastidiosa por seus insetos vetores, e que as diferentes espécies de cigarrinhas apresentam variações na eficiência de aquisição e transmissão (Almeida et al. 2005; Esteves et al. 2019). Na cultura dos citros foram comprovadas 13 espécies vetoras de X. fastidiosa. Dentre essas, Macugonalia leucomelas (Walker, 1951) e Bucephalogonia xanthophis (Berg, 1879) (Hemiptera: Cicadellidae: Cicadellinae) são as que apresentam os maiores valores de eficiência de transmissão, sendo 15,9\% para a primeira e 11,9\% para segunda espécie (Lopes \& Krugner 2016). Estudos recentes conduzidos com a espécie M. leucomelas, utilizando um sistema de dieta artificial para aquisição bacteriana confirmaram que este vetor é um dos que apresentam maiores taxas de transmissão observadas até o momento (Esteves et al. 2019).

\subsubsection{Estratégias de manejo no controle da CVC}

A definição dos fatores envolvidos no estabelecimento e disseminação da doença em pomares cítricos é de fundamental importância para implementação de medidas eficientes de controle. As principais estratégias adotadas no manejo da CVC são baseadas nos princípios de exclusão e erradicação. Os cuidados se iniciam na implantação do pomar, através da aquisição de mudas sadias, provenientes de viveiros certificados e que adotem rígidas medidas sanitárias. Nos pomares já estabelecidos, as práticas culturais envolvem inspeção e identificação de plantas sintomáticas objetivando-se a eliminação de árvores afetadas, no caso de sintomas foliares em vários ramos, ou a poda de ramos contaminados, no caso de de sintomas iniciais restritos a um único ramo (Lopes \& Krugner 2016). 
Com relação ao material vegetal utilizado, sabe-se que todas as varidades de laranjadoce (C. sinensis) são suscetíveis à $X$. fastidiosa. Em contraste, outras espécies cítricas, tais como Citrus reticulata Blanco e seus híbridos são tolerantes e/ou resistentes à doença (ColettaFilho et al. 2007; Niza et al. 2015) e, por isso, seus mecanismos de defesa foram estudados e identificados (de Souza et al. 2007; Pereira et al. 2020). O uso dessas informações aplicadas à engenharia genética pode permitir o desenvolvimento de novas cultivares que seriam importantes para o produtor no enfrentamento da doença.

Outra estratégia importante de manejo da CVC envolve o monitoramento e controle dos insetos vetores. Faz-se necessária a amostragem populacional das cigarrinhas em pelo menos 1 a $2 \%$ da área total do pomar e se constatado ao menos $10 \%$ das plantas do talhão com presença desses insetos, indica-se aplicação de inseticidas como método de controle. Em pomares com plantas mais velhas é recomendado o monitoramento visual e o uso de armadilhas adesivas amarelas para amostragem dos insetos (Yamamoto 2008; Lopes \& Krugner 2016). O monitoramento também deve ser feito em pomares jovens, com até 3 anos pois são mais suscetíveis ao patógeno (Yamamoto et al. 2002a).

Com o aparecimento do Huanglongbing (HLB), também conhecido popularmente como Greening (Coletta-Filho et al. 2004), as pulverizações de inseticidas foram intensificadas com intuito de combater o psilídeo vetor Diaphorina citri (Kuwayama, 1908) (Hemiptera: Liviidae) o que influenciou indiretamente no controle da CVC. O último levantamento realizado pelo Fundecitrus (2019), indicou que a incidência da CVC no Estado de São Paulo e no triângulo mineiro atinge $1,71 \%$ das árvores, sendo a região de Votuporanga a que apresenta os índices mais elevados da doença (6,99\% das árvores infectadas).

Apesar da baixa incidência da doença no estado de São Paulo, na região do Recôncavo Baiano, que responde por $90 \%$ do citros produzido na Bahia, o cenário é diferente. No Litoral Norte do Estado, onde está concentrado o maior número de pomares comerciais, a incidência de CVC atinge $73 \%$ (Coletta-Filho et al. 2020). Embora o manejo da CVC seja eficiente, possibilitando aos citricultores conviver com a doença, os elevados gastos com uso de inseticidas, podas e substituições de árvores infectadas por mudas sadias, reduzem a margem de lucro da cultura (Coletta Filho \& De Souza 2014). Nesse contexto, as pesquisas que utilizam métodos alternativos de controle ganham cada vez mais importância, podendo inclusive, serem usadas no controle curativo das plantas. 


\subsubsection{O uso alternativo da $\mathrm{N}$ - Acetilcisteína no controle da CVC}

Assim como a maioria dos organismos vivos, as plantas são suscetíveis aos estresses bióticos causados por insetos, bactérias, fungos e nematóides. Uma estratégia amplamente utilizada na remissão dos efeitos causados por agentes bióticos é o uso dos agroquímicos como fungicidas e inseticidas. A eficiência da aplicação desses químicos é contrastada com o incremento nos custos de produção, com compra e aplicação, e com a geração de potenciais riscos à saúde humana e animal, considerando toxicidade e persistência no ambiente. Ao longo dos últimos anos novas pesquisas com foco em métodos alternativos que reduzam os riscos ao homem e ao ambiente vem sendo desenvolvidas (Goldstein 2006).

Alternativamente a outros métodos de manejo descritos anteriormente, o uso da molécula antimicrobiana N-Acetilcisteína (NAC) tem apresentado resultados satisfatórios no tratamento curativo de plantas com CVC. O NAC é derivado do aminoácido natural L-cisteína com presença do radical $\mathrm{N}$-acetil. Em seres humanos a molécula é administrada desde a década de 60 no tratamento de infecções no sistema respiratório, e desde os anos 70 no tratamento de pacientes com intoxicação por super dosagem de paracetamol (Blasi et al. 2016; Aldini et al. 2018).

Sua principal função está relacionada a sua capacidade antioxidante que é atribuída a três mecanismos diferentes: i) efeito antioxidante direto, atuando diretamente como molécula antioxidante. ii) efeito antioxidante indireto, agindo como precursor da cisteína que, por sua vez, é fundamental para na síntese da glutationa, a qual atua tanto como molécula antioxidante, bem como substrato para produção de outras enzimas antioxidantes. iii) efeito direto nas ligações de dissulfeto, quebrando as ligações e restaurando os radicais tiol, possibilitando que o mesmo atue diretamente como molécula antioxidante (Nagy 2013; Aldini et al. 2018). O grupo tiol apresenta capacidade redutora (-SH) e, quando se liga à elétrons de radicais livres e de espécies reativas de oxigênio (ROS), reduz a atividade oxidativa no interior da célula, evitando a peroxidação lipídica e estresse oxidativo (Kelly 1998).

Postula-se que o efeito mucolítico se dá através da ruptura das ligações entre as glicoproteínas do muco que apresentam grande peso molecular (Figura 1). Os polímeros de mucina, principais componentes do muco, são formados a partir da ligação entre os monômeros de mucina. As ligações, chamadas de pontes de dissulfeto ocorrem entre os radicais cisteína de cada monômero que estão expostas na superfície externa da bactéria e se rompem através da ação direta do NAC. A presença do radical sulfidril (-SH) na molécula do NAC é capaz de promover a ruptura dessas ligações de dissulfeto por substituição (S-NAC). Com a ruptura do 
biofilme resultante da agregação celular há redução de viscosidade e elasticidade do agregado bacteriano (Aldini et al. 2018). O efeito na redução da produção de exopolissacarídeos e na desagregação das bactérias que formam o biofilme começaram a ser observadas em estudos in vitro, que revelaram inibição do crescimento de bactérias gram-positivas e gram-negativas que causam doenças em humanos como Pseudomonas aeruginosa e Escherichia coli (Parry \& Neu 1977; Marchese et al. 2003; Zhao \& Liu 2010; Muranaka et al. 2013; Picchi et al. 2016).

O NAC pode combater o estresse oxidativo de uma célula ao reagir com os radiciais livres mediante a interação com o radical hidroxila e peróxido de oxigênio (Kelly 1998). Os ROS podem ser produzidos sob diferentes condições e, quando em situação de planta estável, podem desempenhar funções diferentes como a sinalização celular para regulação da expressão gênica, modificação de proteínas, sinalização hormonal e de $\mathrm{Ca}^{+2}$ (Dat et al. 2000). Em situações adversas desencadeadas por estresse hídrico, alterações na intensidade luminosa e na temperatura há maior produção de ROS, sendo necessária a regulação metabólica direcionada à produção de compostos antioxidantes (Ślesak et al. 2007). Os estudos que testaram a importância desses compostos sugeriram que o sistema antioxidante da planta serve para manter o controle do estado redox da planta e não para propiciar a eliminação completa destes elementos (Ślesak et al. 2007). Por exemplo, numa situação de estresse ambiental há aumento da atividade antioxidante, em resposta ao aumento das concentrações de $\mathrm{Ca}^{+2}$ (Havaux 1998). Quando não há equilíbrio, esse íon pode desencadeadar peroxidases lipídicas (Wang et al. 2003).

As propriedades antibacterianas, a presença do grupo tiol que confere estabilidade à molécula, o baixo custo, além do menor risco de contaminação ambiental tornam o NAC um potencial agente no controle de $X$. fastidiosa. Os trabalhos in vivo realizados demonstraram diminuição da população bacteriana em plantas sintomáticas. Muranaka et al. (2013) realizaram testes experimentais com plantas sintomáticas de CVC, os quais indicaram redução da população bacteriana, bem como diminuição dos sintomas na parte aérea da planta. Nos testes in vitro, também houve redução na adesão em superfície de vidro, na formação de biofilme e na concentração de exopolissacarídeos. O efeito do NAC também foi avaliado na bactéria agente causal do cancro cítrico, Xanthomonas citri. Os resultados obtidos demonstraram que a bactéria diminuiu motilidade na planta, formação do biofilme e produção de exopolissacarídeos (Picchi et al. 2016). Com relação as lesões em decorrência de Xanthomonas perforans, foram observadas redução nos sintomas em plantas de tomates, em casa de vegetação, quando houve aplicação do NAC (Qiao et al. 2021). No entanto, ainda não há informações publicadas sobre 
o efeito da molécula do NAC no processo de aquisição e transmissão da bactéria $X$. fastidiosa pelo inseto vetor, o qual é fundamental na epidemiologia da CVC.

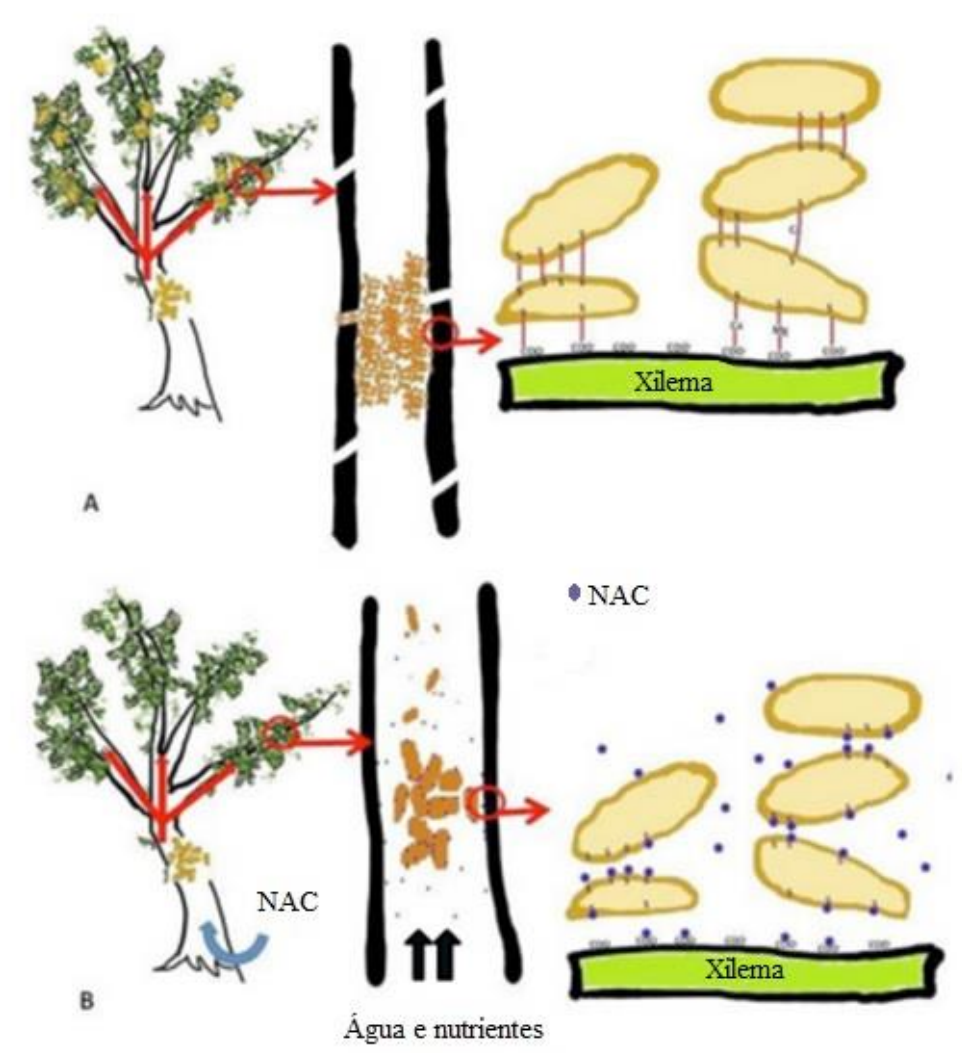

Figura 1. Modelo hipotético da ação do NAC na redução do biofilme formado por $X$. fastidiosa dentro das plantas cítricas. Adaptado de Informativo do Centro de Citricultura, número 200, janeiro de 2012.

\subsubsection{Análise do comportamento alimentar de insetos sugadores}

Os estudos epidemiológicos da CVC, importantes para definição do manejo da doença, incluem o detalhamento do processo de transmissão, que depende do comportamento alimentar dos insetos vetores e pode ser influenciando por diversos fatores. Para tanto, técnicas de monitoramento do comportamento alimentar são usadas a fim de esclarecer quais fatores influenciam as fases de aquisição e inoculação de $X$. fastidiosa e assim elucidar alterações no processo que possam ter implicações na transmissão (Backus et al. 2019; Backus \& Shih 2020).

A técnica de monitoramento do comportamento alimentar, criada para estudar insetos sugadores, foi uma importante ferramenta desenvolvida por McLean \& Kinsey (1964). Inicialmente utilizava corrente alternada (AC) e depois de aprimorada por Tjallingii (1978, 
1985) o sistema passou a utilizar corrente direta (DC) e foi então chamado de electrical penetration graph (EPG) Os dois sistemas medem variações na resistência elétrica (R), e o sistema DC mede também as diferenças de voltagem produzidas na interação inseto-planta, a chamada força eletromotriz (emf) (Tjallingii 1978, 1985). Essa técnica permite estudar o comportamento de prova e atividades estiletares dos insetos dentro dos tecidos vegetais em tempo real.

A técnica consiste em um circuito elétrico que se fecha quando o inseto insere o estilete na planta, no processo de alimentação. De acordo com as atividades estiletares realizadas, ocorrem alterações na voltagem do sistema, em função dos componentes resistência e força eletromotriz. Essas alterações se traduzem em sinais elétricos que por sua vez, são amplificados e registrados em um gráfico. As atividades estiletares específicas podem ser relacionadas à formas de onda característicos (frequência e amplitude) definidos para cada espécie ou grupo de indivíduos (Tjallingii 1978).

Inicialmente, os estudos foram conduzidos com afídeos, e ao passo que a técnica foi aprimorada, outras espécies tiveram seu comportamento alimentar elucidado, e as ondas de EPG caracterizadas. Recentes avanços na técnica do EPG têm possibilitado sua aplicação no desenvolvimento de técnicas para o manejo integrado de pragas. A partir da técnica pode-se estudar como o comportamento alimentar e a oviposição estão relacionados com a transmissão de patógenos; demonstrar o efeito de inseticidas, repelentes ou outros químicos no comportamento alimentare que tem influência direta no dano e/ou na transmissão de patógenos (Backus et al. 2019). O EPG também tem sido utilizado em estudos para identificação de novos hospedeiros, importantes quando se trata de pragas e/ou patógenos quarentenários, uma vez que a avaliação permite ações eficientes na mitigação do risco (Sandanayaka et al. 2013, 2017a).

Desde o início da utilização da técnica do EPG, mais de 50 espécies de hemípteros tiveram seu comportamento alimentar descrito (Cornara et al. 2018). Deste total, poucos foram aqueles que envolveram insetos pertencentes a família Aphophoridae a qual pertence Philaenus spumarius, (Linnaeus, 1758) (Hemiptera: Aphrophoridae) inseto vetor de X. fastidiosa para oliveiras, causadora da Sindrome do Declínio Rápido da Oliveira (Sandanayaka et al. 2013, 2017b; Cornara et al. 2018). Trabalhos recentes sugerem que há similiridade entre as formas de onda produzidos por potenciais vetores de $X$. fastidiosa, e que portanto, as ondas já descritas e caracterizadas podem ser aplicadas à outras espécies (Backus \& Shih 2020).

Há na literatura diversos estudos que avaliam mudanças no comportamento de insetos virulíferos e não- virulíferos. De modo geral, plantas infectadas por vírus sofrem alterações morfológicas e fisiológicas que podem modificar atratividade, preferência e alimentação dos 
vetores (Fereres \& Moreno 2009; Carmo-Sousa et al. 2014). Menos utilizadas, mas não menos importantes outros estudos utilizaram a técnica do EPG em plantas previamente tratadas com uma molécula alvo, afim de averiguar modificações no comportamento alimentar do inseto (Goussain et al. 2005; Carmo-Sousa et al. 2020; Garzo et al. 2020; Maluta et al. 2020). 


\section{MATERIAL E MÉTODOS}

\subsubsection{Obtenção das plantas cítricas, fontes de Xylella fastidiosa, dos insetos e das plantas-teste}

As plantas cítricas usadas como fontes de $X$. fastidiosa foram inoculadas mecanicamente por enxertia, usando-se o sistema de encostia. Um porta-enxerto de limão 'Cravo' (Citrus limonia Osbeck) foi unido aos ramos sintomáticos de uma planta de $C$. sinensis 'Pera' infectada por X. fastidiosa subsp. pauca, estirpe 9a5c (sequence type 13). Após a soldagem, o ramo da planta matriz (C. sinensis) foi cortado e a muda infectada foi transplantada para vasos maiores. As plantas-fonte assim produzidas foram mantidas em estufa com condições semi-controladas (temperatura entre $18-32^{\circ} \mathrm{C}$, sob luz natural) e receberam fertirrigação de macronutrientes $(0,08 \mathrm{~g} / \mathrm{L}$ nitrato de amônio $33 \% \mathrm{~N}, 1 \% \mathrm{~K} ; 0,91 \mathrm{~g} / \mathrm{L}$ nitrato de cálcio - 15,5\% N, $18 \% \mathrm{Ca})$ micronutrientes $\left(0,33 \mathrm{~g} / \mathrm{L}\right.$ de sulfato de magnésio $-1 \%, \mathrm{~K}_{2} \mathrm{O}, 11,8 \% \mathrm{~S}, 9 \% \mathrm{Mg} ; 0,36 \mathrm{~g} / \mathrm{L}$ de nitrato de potássio - $12 \% \mathrm{~N}, 43 \% \mathrm{~K}_{2} \mathrm{O}, 1 \% \mathrm{~S}, 1 \% \mathrm{Mg} ; 0,14 \mathrm{~g} / \mathrm{L}$ de fosfato monoamônico $-12 \% \mathrm{~N}$, $61 \% \mathrm{P}_{2} \mathrm{O}_{5} ; 0,09 \mathrm{~g} / \mathrm{L}$ de ferro $-5 \%$ Fe orto-orto, $6 \%$ quelato de Fe EDTA; 0,03g/L de sulfato de cobre $-24 \% \mathrm{Cu}, 11 \% \mathrm{~S} ; 0,02 \mathrm{~g} / \mathrm{L}$ de sulfato de zinco-20\% Zn, 10\% S) e aplicação de inseticida e acaricida, para controle de cochonilhas e ácaros a cada 15 dias.

Para os experimentos foram obtidos adultos livres de $X$. fastidiosa da cigarrinha vetora M. leucomelas, utilizando-se a metodologia de criação descrita por Esteves et al. (2019). A criação foi mantida em casa de vegetação equipada com sistema de resfriamento do tipo 'padfan' e aquecedor acionados por termostato para manter a temperatura entre $18^{\circ} \mathrm{C}$ a $32^{\circ} \mathrm{C}$. As plantas de Vernonia condensata Backer (falso-boldo) (Asteraceae) e Ocimum basilicum L. (alfavaca) (Lamiaceae), utilizadas como hospedeiras para criação do inseto vetor, foram produzidas de acordo com a demanda, por meio de estaquia (falso-boldo) ou semeadura e transplante (alfavaca).

A espécie vegetal usada como planta-teste nos bioensaios para avaliar a transmissão foi Catharanthus roseus L. (Apocynaceae), popularmente chamada de vinca e já conhecida como hospedeira de X. fastidiosa (Purcell \& Saunders 1999), inclusive de estirpes da subespécie pauca que causam CVC (Esteves et al. 2020). A espécie apresenta crescimento rápido e manifestação dos sintomas precocemente, quando comparada com plantas cítricas (Monteiro et al. 2001). Para produção das plantas-teste, sementes de vinca foram coletadas na cidade de Piracicaba, SP e semeadas em bandejas de isopor com substrato comercial da marca Tropstrato HT/hortaliças, contendo casca de pinus, vermiculita, superfosfato simples e nitrato de potássio. 
Decorridos 14 dias da emergência das plântulas, estas foram transplantadas individualmente para vasos $(15 \mathrm{~cm} \times 28 \mathrm{xcm}$ x $33 \mathrm{~cm})$ contendo o mesmo substrato. O plantio e transplantio foi realizado de acordo com a demanda dos experimentos, sendo que, para cada repetição do experimento, foram utilizadas plantas com aproximadamente $10 \mathrm{~cm}$ de altura.

As plantas-teste e plantas hospedeiras de criação dos insetos foram produzidas e mantidas em viveiro telado a prova de insetos vetores, sendo regadas de acordo com a necessidade e fertirrigadas semanalmente com macro e micronutrientes nas mesmas concentrações descritas para as plantas-fonte.

\subsubsection{Curvas de calibração para detecção de Xylella fastidiosa em diferentes hospedeiros}

Foram construídas três curvas de quantificação de $X$. fastidiosa, com intuito de definir o limiar de distinção de amostras positivas e negativas em cada análise. A diluição padronizada do DNA de $X$. fastidiosa no DNA de citros, vinca e inseto foi realizada para simular as condições nas quais as amostras foram processadas após a coleta (Oliveira et al. 2002). Para construção das curvas, inicialmente, colônias de X. fastidiosa subsp. pauca estirpe 9a5c (ST 13), crescidas em meio PWG sólido por 20 dias $\left(28^{\circ} \mathrm{C}\right.$, no escuro) foram raspadas do meio de cultura e tiveram seu DNA extraído por meio do protocolo descrito por Murray \& Thompson (1980). Para atestar a qualidade e integridade do material extraído, um gel de agarose foi feito, seguida da quantificação no espectofotômetro (Epoch, Biotek). Para curva de quantificação de $X$. fastidiosa em plantas cítricas, o DNA do citros foi extraído a partir de amostras de folhas sadias através do protocolo de extração método do CTAB (Murray \& Thompson 1980). Uma suspensão contendo $2157 \mathrm{ng} / \mu 1$ de $X$. fastidiosa foi diluída 5 vezes, sendo cada diluição de 10 vezes. Outra suspensão contendo $313 \mathrm{ng} / \mu \mathrm{l}$ de DNA de citros também foi diluída 5 vezes. Na etapa seguinte foram misturados $30 \mu 1$ de DNA de $X$. fastidiosa em $70 \mu 1$ de DNA cítrico. A amplificação do DNA foi realizada em um volume total de $20 \mu 1$, sendo $4 \mu 1$ do 5x Hot Fire Pol PROBE qPCR mix plus (ROX) (Applied Biosystems, SP), $1 \mu 1$ de cada conjunto de oligonucleotídeo (CVC 1 ;5'- AGA TGA AAA CAA TCA TGC AAA-3'; CCSM 1; 5'-GCG CAT GCC AAG TCC ATA TTT- 3'); $1 \mu 1$ TaqMan probe TAQ-CVC - (6FAM) 5'AAC CGC AGC AGA AGC CGC TCA TC(TAMRA)-3') (Oliveira et al. 2002), $12 \mu 1$ de água e $2 \mu 1$ da amostra do DNA. A reação foi conduzida no equipamento ViiA7 Real-time PCR System (Applied Biosystems, Foster, CA, USA) nas seguintes condições: um ciclo inicial de 2 minutos a $50^{\circ} \mathrm{C}$, seguido da etapa de desnaturação a $95^{\circ} \mathrm{C}$ por 10 minutos e de 40 ciclos a $95^{\circ} \mathrm{C}$ por 15 
minutos e, anelamento/extensão a $60^{\circ} \mathrm{C}$ por 1 minuto. As amostras foram analisadas em triplicata e continham o controle negativo (água Milli-Q®) e um controle positivo (estirpe 9a5c).

A curva para quantificação do DNA de X. fastidiosa foi estabelecida plotando-se os valores do CT (cycle threshold) (eixo y) em relação ao $\log _{10}$ do número de cópias do RNA ribossomal 16 s de $X$. fastidiosa (eixo x). A equação de regressão linear obtida [y $=-3,2823 \mathrm{x} \log$ (número de cópias de 16sRNA + 31,13; $\left.\mathrm{R}^{2}=0,9986\right]$.

Para a curva de quantificação de $X$. fastidiosa em insetos, outra alíquota do DNA de $X$. fastidiosa foi diluída no DNA total do inseto que continha $475 \mathrm{ng} / \mu 1$ de DNA de insetos sadios oriundos da criação. Na etapa seguinte foram misturados $40 \mu 1$ de DNA de $X$. fastidiosa em 60 $\mu 1$ de DNA total do inseto. A amplificação do DNA foi realizada em um volume total de $20 \mu 1$, com $10 \mu 1$ do SYBR greenROX qPCR (2x) (Thermo Fisher Scientic, SP) $1 \mu 1$ de cada conjunto de oligonucleotídeos (XF16Sr 5'- CCG ATG TAT TCC TCA CCC GTC - 3' XF16Sf 5' - CGG CAG CAC GTT GGT AGT AA - 3') (Li et al. 2013), $6 \mu 1$ de água e $2 \mu 1$ da amostra do DNA. O equipamento utilizado foi o mesmo descrito anteriormente nas seguintes condições: um ciclo de desnaturação a $95^{\circ} \mathrm{C}$ por $10 \mathrm{~min}$, seguido de 40 ciclos de desnaturação a $95^{\circ} \mathrm{C}$ por 15 minutos e anelamento/extensão a $62^{\circ} \mathrm{C}$ por $45 \mathrm{~s}$. As amostras foram analisadas em triplicatas e continham o controle negativo (água Milli-Q®) e um controle positivo. A curva de calibração foi construída plotando-se os valores do CT (cycle threshold) (eixo y) em relação ao $\log _{10}$ do número de cópias do RNA ribossomal 16s de X. fastidiosa (eixo x). A equação de regressão linear obtida $[\mathrm{y}=-3,8357 \mathrm{x} \log$ (número de cópias de $\left.16 \mathrm{sRNA})+36,06 ; \mathrm{R}^{2}=0,9945\right]$. Com base nas concentrações de $X$. fastidiosa obtidas as amostras que apresentaram CT < 30 foram consideradas positivas.

Para comprovação da presença de X. fastidiosa nas plantas-teste, usadas para detecção da transmissão, a curva de calibração foi construída a partir da diluição de 452 ng/ $\mu 1$ de DNA de vincas sadias extraídas de acordo com protocolo descrito por Murray \& Thompson (1980), e diluídas em uma alíquota do DNA de X. fastidiosa, como descrito anteriormente. A reação foi realizada seguindo o que foi descrito para curva de $X$. fastidiosa em citros. A curva de calibração foi contruída plotando-se os valores do CT (cycle threshold) (eixo y) em relação ao $\log _{10}$ do número de cópias do RNA ribossomal 16s de X. fastidiosa (eixo x). A equação de regressão linear obtida $[\mathrm{y}=-4,1355 \mathrm{x} \log$ (número de cópias de $\left.16 \mathrm{sRNA})+36,63 ; \mathrm{R}^{2}=0,9991\right]$. Com base nas concentrações de $X$. fastidiosa obtidas as amostras que apresentaram CT $<31$ foram consideradas positivas. 


\subsection{Detecção de $X$. fastidiosa em adultos de $M$. leucomelas e nas plantas-teste de $C$. roseus}

Para detecção da bactéria nos insetos foi realizada a extração total do DNA seguida da análise de qPCR. As cigarrinhas provenientes dos experimentos tiveram a cabeça separada para a extração, a fim de minimizar a presença de inibidores presentes no restante do corpo do inseto (EPPO 2018). A extração de DNA total dos insetos seguiu a metodologia por Rogers \& Bendich (1988) com protocolo a base de CTAB (Cetyl Trimethyl Ammonium Bromide). Na sequência todas as amostras foram submetidas ao teste de qPCR, em duplicata, para comprovação da aquisição mediante à comparação com a curva padrão previamente estabelecida e anteriormente descrita.

No caso das plantas-teste, a detecção de $X$. fastidiosa iniciou-se com extração de DNA das amostras foliares de C. roseus e seguiu o protocolo descrito por Murray \& Thompson (1980). Após 90 dias do término do experimento, foram coletadas cinco folhas previamente marcadas, nas quais os insetos haviam se alimentado. Após a extração de DNA, as amostras foram submetidas ao teste de qPCR, em procedimento igual ao descrito na construção da curva padrão (item 3.1.2)

Em todas as análises de qPCR aqui descritas, as concentrações de DNA das amostras foram padronizadas (20 a $100 \mathrm{ng} / \mu \mathrm{l}$ ) para PCR quantitativa.

\subsection{Avaliação da eficiência de aquisição de $X$. fastidiosa em plantas-fonte tratadas ou não com NAC e de subsequente transmissão para plantas sadias}

Antes do tratamento com NAC, todas as plantas-fonte de $X$. fastidiosa foram avaliadas quanto à população bacteriana. Inicialmente uma amostra representativa da copa de cada plantafonte, composta de cinco folhas maduras, foi coletada, pesada e dividida. A população bacteriana foi quantificada pelas técnicas de isolamento primário e de qPCR.

O processamento das amostras para isolamento primário foi realizado conforme descrito por Hill \& Purcell (1995a) e adaptado por Almeida et al. (2001). Uma alíquota de $20 \mu \mathrm{l}$ de cada amostra diluída foi plaqueada em meio sólido PWG e incubada em estufa ( $28^{\circ} \mathrm{C}$, sem luz) para crescimento. A bactéria $X$. fastidiosa foi confirmada baseada na morfologia da colônia e no padrão de crescimento característico. A contagem das unidades formadoras de colônias (UFC) foi realizada sob microscópio estereoscópico (aumento de 4x) decorridos 20 dias do plaqueamento. A população bacteriana nas plantas-fonte foi obtida a partir do cálculo de conversão, considerando a média de duas gotas plaqueadas. A concentração bacteriana, medida 
em número de UFC/g de tecido vegetal, foi estimada baseando-se no peso inicial das amostras e diluição, segundo a fórmula: $\mathrm{C}=100 \times(1 / \mathrm{p}) \times \mathrm{n}^{\circ} \mathrm{UFC} \times(10)^{\mathrm{n}}$, onde: $\mathrm{n}=$ fator de diluição e $\mathrm{p}=$ peso da amostra $\mathrm{n}^{\circ} \mathrm{UFC}=$ média de UFC obtidas na contagem das duas gotas plaqueadas. Para a quantificação bacteriana por qPCR, realizou-se extração de DNA das amostras como descrito por Murray \& Thompson (1980), seguida de quantificação como descrito no item 3.1.2.

Após a quantificação da população bacteriana inicial, cada planta-fonte foi envolvida por uma gaiola de acetato e, em cada gaiola, 35 adultos não-sexados de M. leucomelas (com no máximo 2 semanas após emergência), foram confinados por um período de acesso à aquisição (PAA) de 48 h. O experimento foi conduzido em estufa telada, em ambiente semi-controlado (temperatura entre $18^{\circ} \mathrm{C}-32^{\circ} \mathrm{C}$, sob luz natural). Decorrido o período do PAA, os insetos foram transferidos em grupo de três indivíduos para plantas sadias de C. roseus, para o período de acesso à inoculação (PAI) de $72 \mathrm{~h}$ em sala climatizada (temperatura $25 \pm 2^{\circ} \mathrm{C}$, fotoperíodo 14:D 10: N e iluminação artificial 150W). Para possibilitar o acondicionamento dos insetos nas plantas foram utilizadas gaiolas do tipo clipcage $(5,5 \times 4 \mathrm{~cm}$ ) (modelo G320, Gary Plastic Packaging Corp., New York, NY). Após 72 h, os insetos foram retirados das plantas, individualizados e congelados para extração de DNA e detecção de $X$. fastidiosa. As plantas de vinca, devidamente identificadas, foram colocadas em estufa telada com condições semicontroladas (temperatura entre $18^{\circ} \mathrm{C}-32^{\circ} \mathrm{C}$, luz natural) para desenvolvimento. Amostras foliares foram coletadas para extração de DNA e detecção de X. fastidiosa por qPCR 90 dias após o PAI.

Após a avaliação inicial $(\mathrm{T}=0)$ de aquisição e subsequente transmissão de $X$. fastidiosa por cigarrinhas, as plantas-fonte receberam a aplicação dos tratamentos. Foram adicionados 15 g do NAC peletizado $\left(3 \mathrm{~N}: 10 \mathrm{P}_{2} \mathrm{O}_{5}: 10 \mathrm{~K}_{2} \mathrm{O}+\mathrm{NAC}\right.$; proporção $2 \mathrm{~g}$ de NAC para cada $1 \mathrm{Kg}$ do fertilizante) distribuídos em cada vaso e incorporados superficialmente. Nas plantas pertencentes ao controle foram aplicados $15 \mathrm{~g}$ do fertilizante húmico, sem NAC $\left(3 \mathrm{~N}: 10 \mathrm{P}_{2} \mathrm{O}_{5}: 10 \mathrm{~K}_{2} \mathrm{O}\right)$. Reaplicações dos tratamentos foram feitas a cada 30 dias. Passados 90 dias após o tratamento inicial $(\mathrm{T}=90)$, novos ensaios de aquisição e de transmissão foram montados para avaliação comparativa. As etapas sequenciais do experimento estão representadas na Figura 2. 

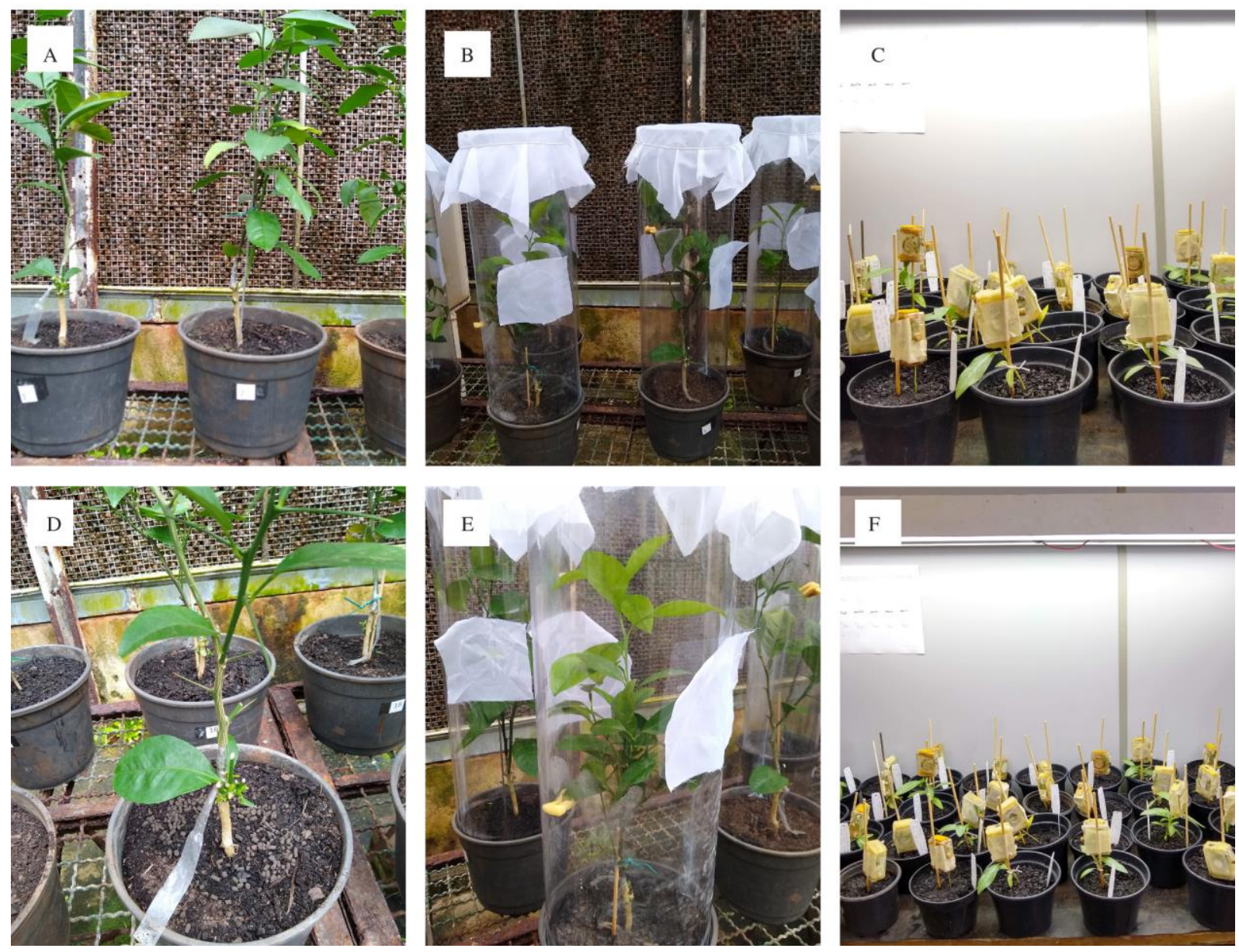

Figura 2. Esquema sequencial do experimento de avaliação da eficiência de aquisição de $X$. fastidiosa em plantas-fonte tratadas ou não com NAC, e subsequente transmissão para plantas-teste, ilustrando-se as etapas de aquisição e inoculação de X. fastidiosa por adultos de M. leucomelas nos tempos $\mathrm{T}=0$ e $\mathrm{T}=90$ dias. A. Plantas cítricas infectadas por $X$. fastidiosa (plantas-fonte) cuja concentração bacteriana foi quantificada; B. Plantas-fonte sobre as quais os adultos de $M$. leucomelas foram confinados para um período de acesso a aquisição (PAA) de $48 \mathrm{~h}$; C. Plantasteste de C. roseus, sobre as quais adultos de M. leucomelas foram confinados (em grupos de três) em gaiolas do tipo clipcage, para um período de acesso à inoculação (PAI) de $72 \mathrm{~h}$; D. Plantas-fonte com o tratamento aplicado (NAC e controle) por meio da incorporação superficial do fertilizante húmico; E. Plantas-fonte após 90 dias de tratamento $(\mathrm{T}=90)$, sobre as quais novos insetos foram confinados para o PAA de $48 \mathrm{~h} ; \mathbf{F}$. Plantas-teste de C. roseus, para as quais adultos de M. leucomelas foram transferidos (em grupos de três) para PAI de $72 \mathrm{~h}$.

Assim, neste experimento foram avaliadas a aquisição e inoculação no tempo $\mathrm{T}=0$, antes da aplicação dos tratamentos e no tempo $\mathrm{T}=90$, após 90 dias de tratamento. O delineamento experimental foi em blocos inteiramente casualizados com duas repetições no tempo, entre janeiro e dezembro de 2019. Foram avaliadas 3 plantas-fonte por tratamento em cada ensaio. Cada bloco foi constituído a partir de uma planta-fonte, avaliando-se por qPCR, 30 insetos que se alimentaram sobre a planta-fonte para determinar a eficiência de aquisição e, 10 plantas-teste de C. roseus, sobre as quais os insetos foram confinados para o PAI, a fim de determinar a eficiência de transmissão. Os dados de quantificação bacteriana por qPCR e isolamento 
primário em $\mathrm{T}=0$ e $\mathrm{T}=90$ foram comparados aplicando-se modelos lineares mistos (LM), ajustados com máximo verossimilhança restrita, pacote lmerTest. A proporção de insetos que adquiriram a bactéria (taxa de aquisição) e a de plantas-teste positivas (taxa de transmissão) foram comparados entre os tratamentos usando modelos lineares generalizados mistos (GLM), ajustados com máxima verossimilhança (RML), pacote lme4. A probabilidade média de transmissão por indivíduo foi estimada de acordo com Swallow (1985). Todas as análises foram conduzidas no software R 4.0.0 (R Core Team 2019). Foram considerados significativas as interações cujo $\mathrm{p}<0,05$.

\subsection{Avaliação do efeito do NAC na transmissão de $X$. fastidiosa após a aquisição da bactéria pelo vetor}

Neste experimento, adultos da cigarrinha M. leucomelas foram alimentados em seedlings sadios de citros tratados com solução nutritiva contendo NAC, após a aquisição de X. fastidiosa em dieta artifical. O primeiro passo foi a montagem do sistema de fornecimento da solução nutritiva às plantas. Para isso, seedlings de $C$. sinensis 'Hamilin' foram transplantadas para os vasos de Leonard (garrafas de vidro cortadas ao meio, invertidas e posicionadas sobre o fundo da mesma garrafa) contendo areia e vermiculita na proporção (2:1). As plantas receberam a solução nutritiva de Hoagland \& Arnon (1950) com NAC no tratamento e sem NAC no controle, por 7 dias. Para aplicação do tratamento 0,0251g de NAC (Sigma-Aldrich. pureza $\geq$ 99\%; peso molecular $163,19 \mathrm{~g} / \mathrm{mol}$ ) foram pesados e diluídos com auxílio de agitador magnético em $200 \mathrm{~mL}$ de solução nutritiva. Em seguida o $\mathrm{pH}$ foi medido e ajustado para 6,81 $(\mathrm{NaOH} 10 \mathrm{~N})$. A solução foi completada para volume final de $250 \mathrm{~mL}$, e colocada na parte inferior da garrafa identificada com o tratamento (concentração final 0,1 mg/ml). As plantas cítricas foram usadas nos ensaios após 7 dias.

Para a formulação da dieta artifical para aquisição do patógeno in vitro, a estirpe 9a5c de $X$. fastidiosa subsp. pauca foi recuperada do ultrafreezer $\left(-80^{\circ} \mathrm{C}\right)$, plaqueada em meio de cultura PWG (Hill \& Purcell 1995b) e colocada para crescimento em estufa (temperatura de $28^{\circ} \mathrm{C}$, sem luz). Após crescimento ( $\cong 20$ dias), as colônias foram raspadas, ressuspendidas em tampão fosfato salino (phosphate buffered saline- PBS) e plaqueadas em meio XFM (Xylella fastidiosa medium) (Almeida et al. 2004) por duas vezes, para multiplicação. As colônias obtidas foram raspadas e ressuspendidas em dieta artificial (0,7 mM L-glutamina, 0,1 mM Lasparagina, 1 mM citrato de sódio, ph 6,4) (Killiny \& Almeida 2009a) obtendo-se uma OD $_{600 \mathrm{~nm}}$ 
de $0,6\left(10^{8} \mathrm{UFC} / \mathrm{ml}\right)$. A dieta contendo células bacterianas foram oferecidas aos insetos em sistema de sachê montado em tubo plástico $(\varnothing=1 \mathrm{~cm}$; comprimento $=3 \mathrm{~cm}) \mathrm{com}$ as duas extremidades abertas. Em uma delas foi colocada uma camada de parafilme (Parafim $®$ ), sob a qual foi depositada a bactéria ressuspendida na dieta (gota de $35 \mu \mathrm{l}$ ), e em seguida recoberta por outra camada de parafilme. Antes de serem adicionados ao sistema de sachê, os insetos passaram por jejum de $1 \mathrm{~h}$. Foram colocados individualmente, pela extremidade aberta, que foi vedada com uma borracha, possibilitando trocas gasosas e, permaneceram no PAA por $6 \mathrm{~h}$. Após o PAA, os insetos foram confinados em grupos de 30 indivíduos sobre plantas de $V$. condensata, que é uma planta não hospedeira de estirpes de $X$. fastidiosa de citros (Marucci et al. 2003) para lavagem do tubo digestivo por 24 h, de modo a eliminar células bacterianas não aderidas aos sítios de retenção no estomodeu.

Após o PAA de $X$. fastidiosa in vitro, os insetos foram confinados em grupos de 10 indivíduos sobre os seedlings de citros dos tratamentos com NAC e sem NAC (controle) por diferentes períodos de exposição $(24,72$ e 120 h). Após o fim do tratamento os insetos foram confinados em grupos de 3, em plantas-teste de $C$. roseus e submetidos a um PAI de 72 h. A mortalidade foi avaliada a cada $24 \mathrm{~h}$ para controle da aceitabilidade das plantas-teste utilizadas. Todas as etapas do experimento foram conduzidas em sala climatizada (temperatura $25 \pm 2^{\circ} \mathrm{C}$, fotoperíodo 14:D 10:N e iluminação artificial 150W). As etapas sequenciais do experimento estão representadas na Figura 3. A taxa de aquisição foi avaliada por meio dos insetos utilizados no experimento que foram individualizados e mantidos em freezer para posterior extração de DNA e deteção de $X$. fastidiosa por qPCR. Foram analisados os insetos que sobreviveram a todas as etapas do experimento. A eficiência de transmissão foi avaliada a partir das plantasteste de C. roseus, que foram devidamente identificadas, e colocadas em estufa telada (temperatura entre $18^{\circ} \mathrm{C}-32^{\circ} \mathrm{C}$, luz natural) para desenvolvimento. Amostragens foliares para extração de DNA e detecção de $X$. fastidiosa foram realizadas 90 dias após o PAI.

$\mathrm{O}$ experimento foi conduzido em blocos casualizados completos, com quatro repetições entre abril e setembro de 2019. Para compor as repetições de cada período de exposição (24, 72, $120 \mathrm{~h}$ ) ao NAC ou controle em seedlings de C. sinensis, 20 insetos foram inicialmente submetidos ao PAA da bactéria em dieta artificial, seguido do período de alimentação de $24 \mathrm{~h}$ em $V$. condensata e da sequência dos tratamentos nos diferentes períodos de exposição ao NAC. Após essas etapas, os insetos sobreviventes foram submetidos ao PAI em plantas-teste de $C$. roseus ( 3 insetos por planta) para avaliar a taxa de transmissão; assim, o número de plantas de C. roseus inoculadas por repetição variou de 1 a 7 dependendo da sobrevivência dos insetos. 
Para a avaliação do efeito dos fatores experimentais tempo de exposição (24, 72,120 h) e tratamento com e sem NAC, ajustou-se o modelo linear generalizado assumindo a especificação quasi-Binomial, visto que a variável resposta foi o número de insetos positivos por qPCR para $X$. fastidiosa em relação ao total de insetos expostos em cada unidade experimental (planta de C. sinensis tratada ou não com NAC). A probabilidade média de transmissão foi apresentada em porcentagem, com base no número de plantas-teste de $C$. roseus positivas para X. fastidiosa e a probabilidade de transmissão por indivíduo, estimada de acordo com Swallow (1985). A absorção de solução nutritiva foi avaliada a partir da ANOVA univariada, seguida do teste Tukey para comparação das médias. Todas as análises foram realizadas no software R 4.0.0 (R Core Team 2019). 

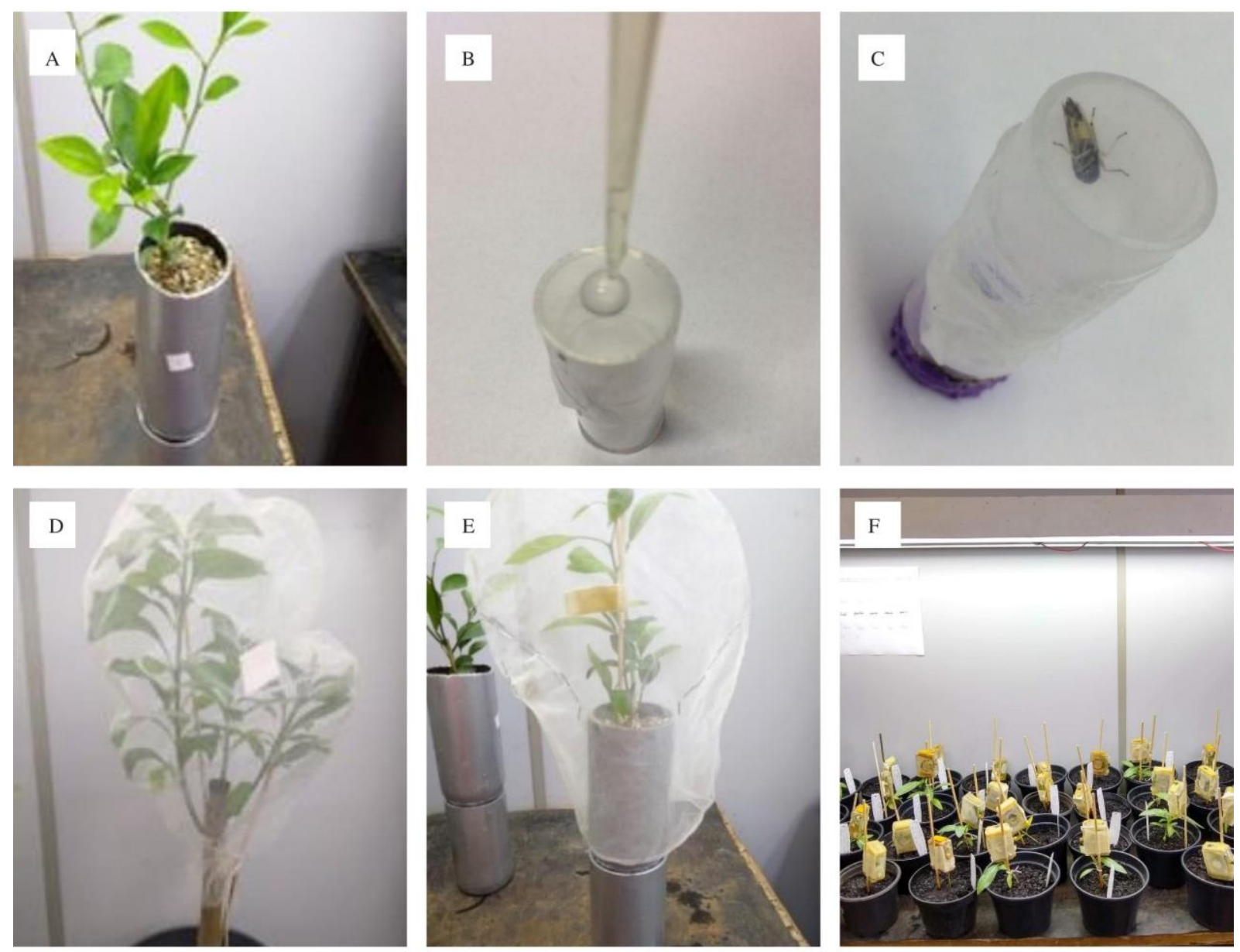

Figura 3. Esquema sequencial das etapas do experimento de avaliação do efeito de NAC na transmissão de $X$. fastidiosa por adultos de M. leucomelas, após a aquisição da bactéria em dieta artificial. A. Vaso de Leonard para fornecimento de solução nutritiva com NAC e sem NAC às plantas cítricas sadias; B. Membrana de parafilme sobre o qual foi colocada a gota de dieta artificial com a bactéria $X$. fastidiosa e, subsequentemente, uma segunda membrana para montagem do sachê de alimentação. C. Adultos de M. leucomelas confinados individualmente por um período de acesso a aquisição (PAA) de $6 \mathrm{~h}$ na dieta artificial; D. Planta de Vernonia condensata sobre a qual os adultos de $M$. leucomelas foram colocados por $24 \mathrm{~h}$, para lavagem dos estiletes e tubo digestivo, logo após o PAA. E. Plantas cítricas sadias tratadas com NAC e controle (sem NAC) por 7 dias, sobre as quais os adultos de $M$. leucomelas foram transferidos e permaneceram alimentando-se por diferentes períodos (tratamentos de 24, $72 \mathrm{e} 120 \mathrm{~h}$ ). F. Plantas-teste de $C$. roseus sobre as quais foram montadas gaiolas do tipo clipcage, para confinamento dos adultos de M. leucomelas (grupos de 3 indivíduos) que passaram pelos referidos tratamentos, para um período de acesso à inoculação (PAI) de $72 \mathrm{~h}$.

\subsection{Avaliação da transmissão de $X$. fastidiosa para plantas-teste sadias, previamente}

\section{tratadas ou não com NAC}

A aquisição da bactéria foi realizada em plantas-fonte de citros que foram envolvidas por uma gaiola de acetato e, sobre as quais, 30 adultos não sexados de $M$. leucomelas (com no 
máximo 2 semanas após emergência) foram confinadas por um PAA de 48 h. Esta etapa do experimento foi conduzida em estufa telada (temperatura entre $18^{\circ} \mathrm{C}$ e $32^{\circ} \mathrm{C}$, luz natural).

Decorrido o PAA, os insetos foram transferidos, em grupos de 3 indivíduos, para plantas sadias de C. roseus (plantas-teste) que receberam um tratamento prévio por 30 dias. Foram incorporados em cada vaso, $5 \mathrm{~g}$ do fertilizante húmico com NAC no tratamento (3N: $10 \mathrm{P}_{2} \mathrm{O}_{5}: 10 \mathrm{~K}_{2} \mathrm{O}+\mathrm{NAC}$; proporção $2 \mathrm{~g}$ de NAC para cada $1 \mathrm{Kg}$ do fertilizante) e a mesma quantidade de fertilizante húmico sem NAC, no controle. Os grupos de três insetos foram confinados sobre as plantas-teste com auxílio de gaiolas do tipo clip-cage por um PAI por 72 h, em sala climatizada (temperatura $25 \pm 2^{\circ} \mathrm{C}$, fotoperíodo 14:D 10:N e iluminação artificial 150W). As etapas sequenciais do experimento estão representadas na Figura 4.
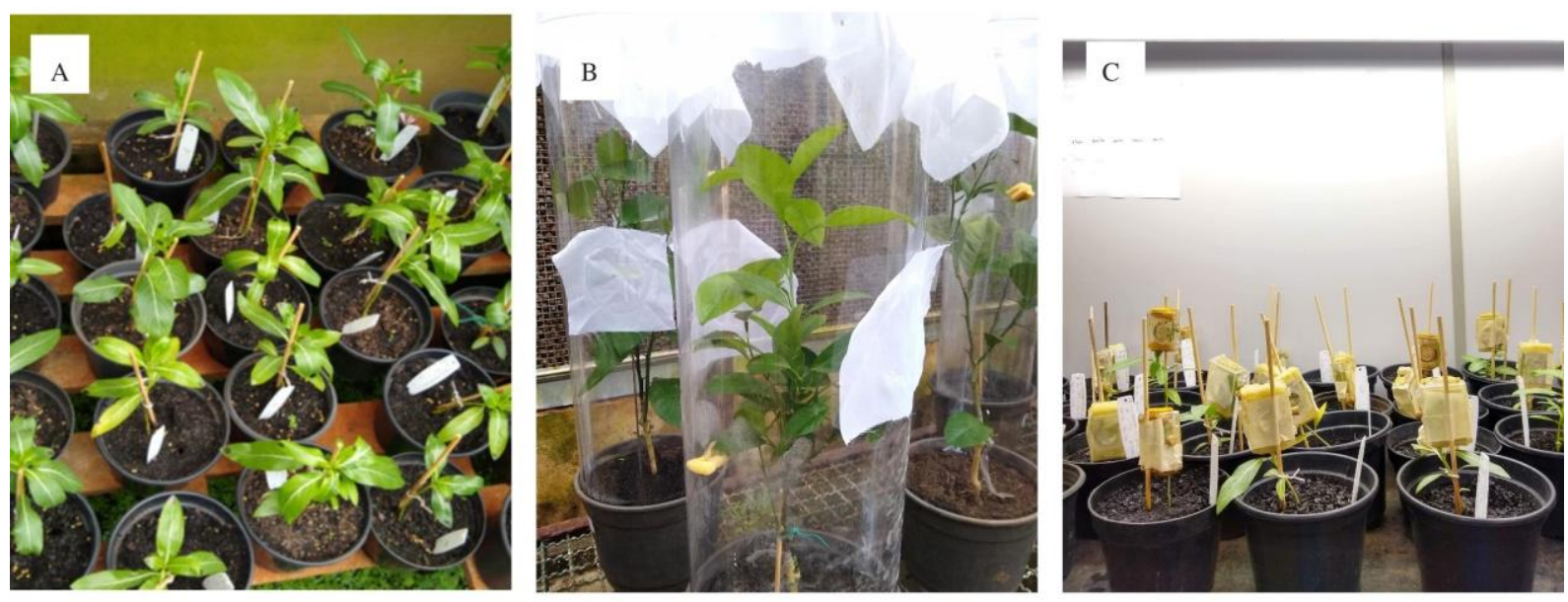

Figura 4. Esquema sequencial das etapas do experimento de transmissão de $X$. fastidiosa por adultos de $M$. leucomelas para plantas-teste de $C$. roseus, previamente tratadas ou não com NAC. A. Plantas de $C$. roseus após 30 dias de tratamento com NAC. B. Plantas de $C$. sinensis infectadas por $X$. fastidiosa (plantas-fonte) sobre as quais adultos de M. leucomelas foram confinados por um período de acesso à aquisição de 48 h. C. Plantas sadias de C. roseus (plantas-teste) sobre as quais foram montadas gaiolas do tipo clipcage, para confinamento dos adultos de M.leucomelas (grupos de 3 insetos por planta), para período de acesso à inoculação de $72 \mathrm{~h}$.

Os mesmos parâmetros descritos no experimento anterior (item 3.4) foram avaliados neste experimento: taxa de aquisição, a partir da extração de DNA dos insetos e deteção de $X$. fastidiosa por qPCR; e taxa de transmissão por meio da extração de DNA do material foliar das plantas-teste de $C$. roseus, num período compreendido após 90 dias do experimento, seguida detecção de $X$. fastidiosa por qPCR.

O experimento foi conduzido em blocos inteiramente casualizados, com três repetições no tempo entre abril de 2019 e setembro de 2019. A taxa de aquisição foi determinada a partir da média de insetos positivos em relação ao total testado nos ensaios. As taxas médias de 
transmissão foram calculadas com base nos dados de proporção de plantas-teste infectadas após inoculação pelos grupos de três insetosusando-se modelos lineares generalizados (GLM), pacote car. A probabilidade de transmissão por indivíduo foi estimada de acordo com Swallow (1985). Todas as análises foram conduzidas no software R 4.0.0 (R Core Team 2019). Foram considerados significantes as interações cujo $\mathrm{p}<0,05$.

\subsection{Comportamento alimentar de Philaenus spumarius em plantas de Sonchus oleraceus após tratamento com NAC em fertilizante húmico}

O efeito de tratamento de plantas com NAC sobre o comportamento alimentar de um inseto vetor foi estudado para a cigarrinha $P$. spumarius, que transmite $X$. fastidiosa em oliveiras na Europa. O estudo foi realizado em uma planta hospedeira herbácea desse inseto, a serralha, Sonchus oleraceus L. (Asteraceae). A primeira etapa do experimento foi o preparo das plantas tratadas e não tratadas com NAC. Para isso, sementes de S. oleraceus foram colocadas para germinação em placas contendo vermiculita, em câmara de crescimento (temperatura: $18^{\circ} \mathrm{C}$ dia/ $23^{\circ} \mathrm{C}$ noite, fotoperíodo 14D:10N e umidade de $60 \%$ ). Após a germinação as plântulas foram transferidas para vasos $(430 \mathrm{~mL})$ contendo substrato e vermiculita na proporção 2:1. Decorridos 7 dias do transplantio foram aplicados $5 \mathrm{~g}$ do NAC agri ${ }^{\circledR}$ $\left(3 \mathrm{~N}: 10 \mathrm{P}_{2} \mathrm{O}_{5}: 10 \mathrm{~K}_{2} \mathrm{O}+\mathrm{NAC}\right.$; proporção $2 \mathrm{~g}$ de NAC para cada $1 \mathrm{Kg}$ fo fertilizante) no tratamento e $5 \mathrm{~g}$ do fertilizante húmico sem NAC $\left(3 \mathrm{~N}: 10 \mathrm{P}_{2} \mathrm{O}_{5}: 10 \mathrm{~K}_{2} \mathrm{O}\right)$ no tratamento controle. As quantidades foram distribuídas em cada vaso e incorporadas superficialmente. Foram preparadas, também, plantas de $S$. oleraceus para o controle positivo, sem tratamentos prévio, e que receberam aplicação de inseticida $24 \mathrm{~h}$ antes da montagem do ensaio. As plantas foram mantidas em câmara de crescimento com condições controladas (temperatura: $18^{\circ} \mathrm{C} \mathrm{dia} / 23^{\circ} \mathrm{C}$ noite, fotoperíodo 14D:10N e umidade de 60\%) e foram regadas duas vezes na semana, com solução nutritiva na concentração 1 g/L (N: P: K 20-20-20; Miller Chemical \& Fertilizer. Hanover. PA. USA) (Figura 5-B). O inseticida imidacloprid (Confidor ${ }^{\circledR} 20 \mathrm{LS} ; 200 \mathrm{~g} \mathrm{IA}^{-1}$ ) foi pulverizado sobre as plantas de $S$. oleraceus (concentração $100 \mathrm{mg} \mathrm{IA} \mathrm{L}^{-1}$ ) 24 h antes da realização do ensaio. O ensaio foi conduzido decorridos 45 dias de aplicação dos tratamentos.

Adultos de P. spumarius (Figura 5-A) foram coletados em regiões da Comunidade de Madri, Espanha e Bragança, Portugal, no final da primavera de 2019. Os insetos foram mantidos em câmaras, com condições de temperatura e umidade controladas (temperatura: $18^{\circ} \mathrm{C}$ dia/ $23^{\circ} \mathrm{C}$ noite, fotoperíodo 14D:10N e umidade de $60 \%$ ), em plantas de S. oleraceus. 
Para o ensaio de EPG, adultos de P. spumarius foram individualizados, sexados e colocados em jejum por $1 \mathrm{~h}$. Em seguida foram adormecidos com $\mathrm{CO}_{2}$ e imobilizados em bomba de vácuo, sob um microscópio estereoscópico, com o dorso voltado para cima. Sobre o pronoto foi colado um fio de ouro $(20 \mu \mathrm{m}$ de $\varnothing ; 3 \mathrm{~cm}$ de comprimento), com cola de prata condutora (base de água). A outra ponta do fio de ouro foi colada ao eletrodo de cobre (1 mm de $\varnothing ; 3 \mathrm{~cm}$ de comprimento). O eletrodo foi acoplado ao equipamento de corrente direta (DC) (modelo Giga -8d. com software Stylet + para Windows; EPG- systems. Wageningen, The Netherlands).
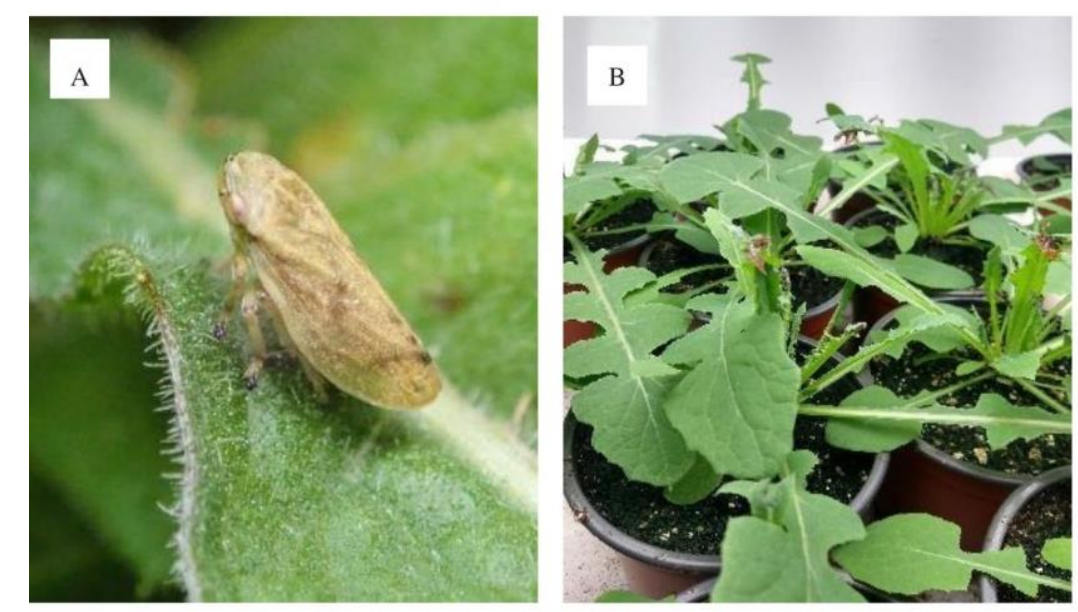

Figura 5. A. Adulto de P. spumarius sobre folha de S. oleraceus. B. Plantas de S. oleraceus mantidas em câmara de crescimento durante tratamento com e sem NAC e para o tratamento com inseticida.

\subsection{Estudo de EPG de Philaenus spumarius em S. oleraceus tratadas com NAC via solução nutritiva}

As sementes de S. oleraceus foram preparadas como descrito anteriormente (item 3.6). Após germinação, as plântulas foram transplantadas para os vasos de Leonard, feitos manualmente com garrafas de água de $200 \mathrm{~mL}$. As garrafas de plástico foram cortadas ao meio e envoltas por fita adesiva preta, para evitar a entrada de luz. Para o transplantio, a proporção de areia e vermiculita correspondeu a 2:1, respectivamente. Os tratamentos foram aplicados logo após esta etapa. Nas plantas do controle foram adicionadas na parte de baixo da garrafa apenas solução nutritiva Hoagland \& Arnon (1950). Naquelas que corresponderam ao tratamento, foram adicionadas solução nutritiva $+\mathrm{NAC}$ a $1 \mathrm{mg} / \mathrm{mL}(\mathrm{pH}$ ajustado à 6,8$)$. A solução nutritiva foi reposta e quantificada a cada 7 dias. As plantas foram mantidas por 45 
dias em câmara com condições controladas (temperatura: $18^{\circ} \mathrm{C}$ dia $/ 23^{\circ} \mathrm{C}$ noite, lâmpada violeta e umidade de $60 \%$ ).

Para este ensaio foram utilizados adultos de P. spumarius coletados na região de MurciaEspanha, no final do inverno de 2020. Os insetos foram preparados para os ensaios de EPG como descrito no item 3.6 e as plantas posicionadas sobre o equipamento para condução dos testes (Figura 6).

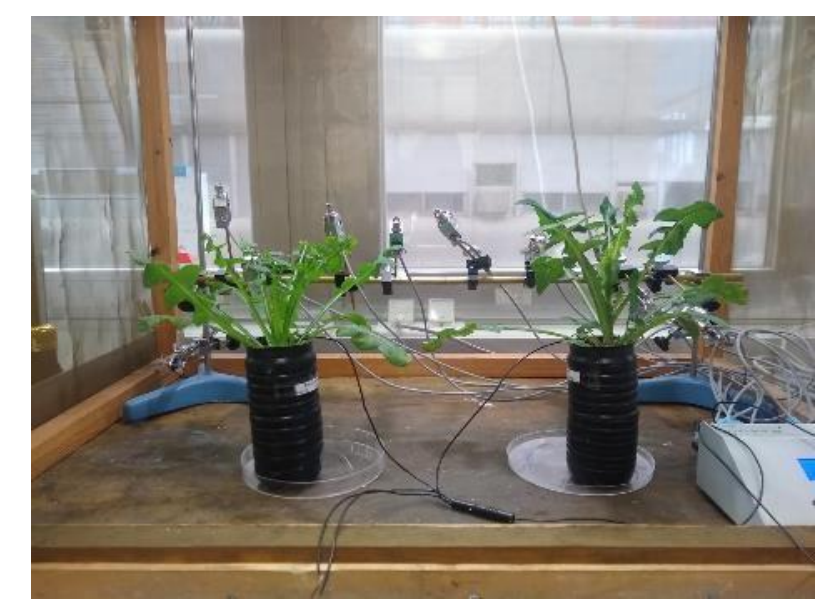

Figura 6. Plantas de S. oleraceus conectadas ao equipamento de EPG para condução dos testes.

\subsubsection{Marcação das formas de onda de EPG e análise estatística}

Após a coleta dos dados, as ondas foram marcadas com auxilio do programa Stylet a. (versão 1.3.10.27). As seguintes formas de ondas foram caracterizadas de acordo com a amplitude, frequência e voltagem, conforme descrito por Cornara et al. (2018): np: não prova (estiletes fora do tecido vegetal); C: primeiro forma de onda observada quando o inseto insere os estiletes na planta, relacionada com a salivação para formação da bainha estiletar e exploração do tecido vegetal em direção aos vasos de xilema; Xc: primeiro contato com o xilema e possível pré-ingestão/ingestão de prova; Xi: ingestão ativa do fluído xilemático, podendo ocorrer em baixa e alta frequência; R: geralmente ocorre entre eventos de Xi, indicando suspensão temporária de ingestão do fluído xilemático; $\mathrm{N}$ : corresponde a uma queda de potencial, durante Xc e Xi, sem significado biológico conhecido.

As variáveis de EPG sequenciais e não sequenciais foram estimados a partir da planilha excel Workbook desenvolvida para insetos sugadores de xilema, como P. spumarius (Antonio J. Alvarez; Universidad de Almeria. Espanha). As variáveis selecionadas (média \pm EPM) foram calculadas conforme descrito por Backus et al. (2007). As variáveis não-sequenciais analisadas 
foram: PPW, proporção de indivíduos que realizaram uma forma específica de onda; NWEI, número de vezes que se realizou uma determinada forma de onda por inseto, calculada pelo somatório do número de eventos de uma determinada forma de onda realizados por cada indivíduo, dividido pelo número total de insetos; WDI, duração de uma determinada forma de onda por inseto (somatório das durações dos eventos da respectiva forma de onda por cada indivíduo, dividido pelo número total de insetos que realizaram tal forma de onda); número de provas; número de provas com Xi (número de provas em que o inseto ingeriu seiva do xilema); número de provas com alimentação em Xi sustentada (número de provas em que o inseto ingeriu seiva no xilema por mais de $10 \mathrm{~min}$ ).

As variáveis sequenciais foram: tempo entre início do EPG e a primeira Xc; tempo entre início do EPG e a primeira Xi; tempo do começo da prova até a primeira Xc; tempo do começo da prova à primeira $\mathrm{Xc}$, tempo do começo da prova à primeira $\mathrm{Xi}$; tempo do início do EPG à primeira $\mathrm{Xi}>10 \mathrm{~min}$; tempo do início da prova à primeira $\mathrm{Xi}>10 \mathrm{~min}$ Cornara et al.(2018).

No primeiro experimento (item 3.6) as médias foram calculadas com dados de registros de EPG de 25 indivíduos (machos e fêmeas) expostos às plantas do controle (fertilizante húmico sem NAC), 22 indivíduos (machos e fêmeas) expostos às plantas do tratamento com NAC (fertilizante húmico com NAC) e outros 22 indivíduos (machos e fêmeas) expostos às plantas tratadas com inseticida. As variáveis sequenciais e não sequenciais foram comparadas entre os tratamentos com o teste não paramétrico de análise multivariada da variância (MANOVA) no software IBM® SPSSStatistics, versão 25.

No segundo experimento (item 3.7), as médias foram calculadas a partir dos dados de 20 fêmeas expostas à alimentação em plantas tratadas com NAC e 20 fêmeas expostas à alimentação em plantas do controle. As variáveis sequenciais e não sequenciais foram comparadas entre os tratamentos com o teste não paramétrico de análise multivariada da variância (MANOVA), submetidas a análises estatísticas com o software IBM® SPSSStatistics, versão 25 (IBM Corp. Armonk, NY). Calcularam-se as médias semanais de absorção da solução nutritiva com NAC e sem NAC, durante o desenvolvimento das plantas. Os dados foram analisados no software R 4.0.0 (R Core Team 2019), a partir dos Modelos Lineares Generalizados Mistos (GLLMs), com regressão binomial negativa, plotando-se tratamento e semanas como fatores fixos. 


\section{RESULTADOS}

\subsection{Avaliação da eficiência de aquisição de $X$. fastidiosa em plantas-fonte tratadas ou não com NAC e de subsequente transmissão para plantas sadias}

A população de $X$. fastidiosa nas plantas-fonte de citros avaliadas antes ( $\mathrm{T}=0)$ e 90 dias após a aplicação ( $\mathrm{T}=90)$ do fertilizante húmico não diferiu estatisticamente entre os tratamentos com e sem NAC tanto na avaliação por isolamento primário $(\mathrm{F}=7,94 ; \mathrm{df}=2 ; \mathrm{p}=0,11)$, como na avaliação por $\mathrm{qPCR}(\mathrm{F}=3,51 ; \mathrm{df}=2 ; \mathrm{p}=0,22)$. Por isolamento primário, as plantas do Controle $\mathrm{T}=0$ apresentaram número médio de unidades formadoras de colônias (UFC) de $X$. fastidiosa por g de tecido cítrico ( $\log 6,44 \pm 0,69)$ semelhante ao de plantas tratadas com NAC no $\mathrm{T}=90(\log 5,72 \pm 0,72)$ (Figura 7-A). A média do log do número de células de X. fastidiosa estimadas por qPCR no Controle $\mathrm{T}=0(5,86 \pm 0,65)$ foi semelhante às observadas em $\mathrm{T}=90$ nas plantas tratadas com NAC $(4,07 \pm 0,65)$ e Controle $(5,34 \pm 0,65)$ (Figura 7-B).

Para comparar o efeito da aplicação do NAC na população bacteriana das plantas cítricas no $\mathrm{T}=90$, os valores médios referentes ao tempo $\mathrm{T}=0$ foram considerados como $100 \%$ e a partir dele foi estimada a redução na população bacteriana após 90 dias de tratamento. Os valores para as plantas tratadas e não tratadas com NAC, tanto na avaliação pela técnica de isolamento primário como por qPCR estão descritos na Figura 8-B. Os percentuais de redução em população bacteriana, calculados a partir do qPCR, de plantas submetidas ao tratamento com NAC foram de até $30 \%$ aos 90 dias, mas não diferiram estatisticamente do Controle (sem NAC). 
A
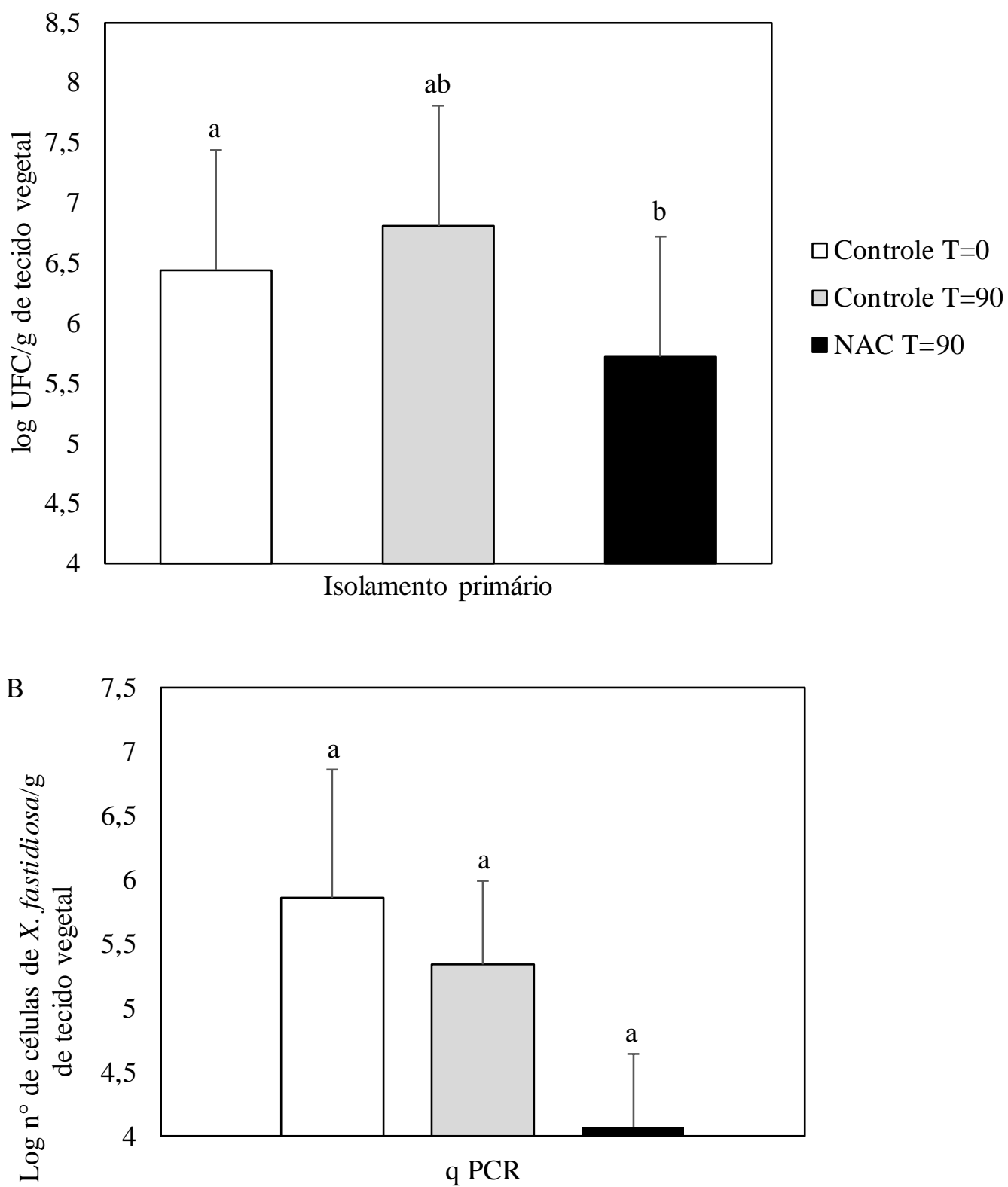

Figura 7. Quantificação da população de X. fastidiosa em plantas cítricas antes $(\mathrm{T}=0)$ e 90 dias após ( $\mathrm{T}=90)$ a aplicação de fertilizante com N-Acetilcisteína (NAC) ou sem (Controle). A. Log do número de unidades formadoras de colônias (UFC)/g estimado por isolamento primário; B. Log do número de células de $X$. fastidiosa/g calculadas a partir da técnica do qPCR. Os valores representam as médias de dois ensaios repetidos no tempo a partir de plantas-fonte correspondentes aos tratamentos Controle $\mathrm{T}=0(\mathrm{n}=12)$, Controle $\mathrm{T}=90(\mathrm{n}=6)$ e NAC $\mathrm{T}=90(\mathrm{n}=6)$. As barras representam o erro padrão da média. Médias com as mesmas letras não diferem entre si pela Anova, com $\mathrm{p} \leq$ 0,05 . 

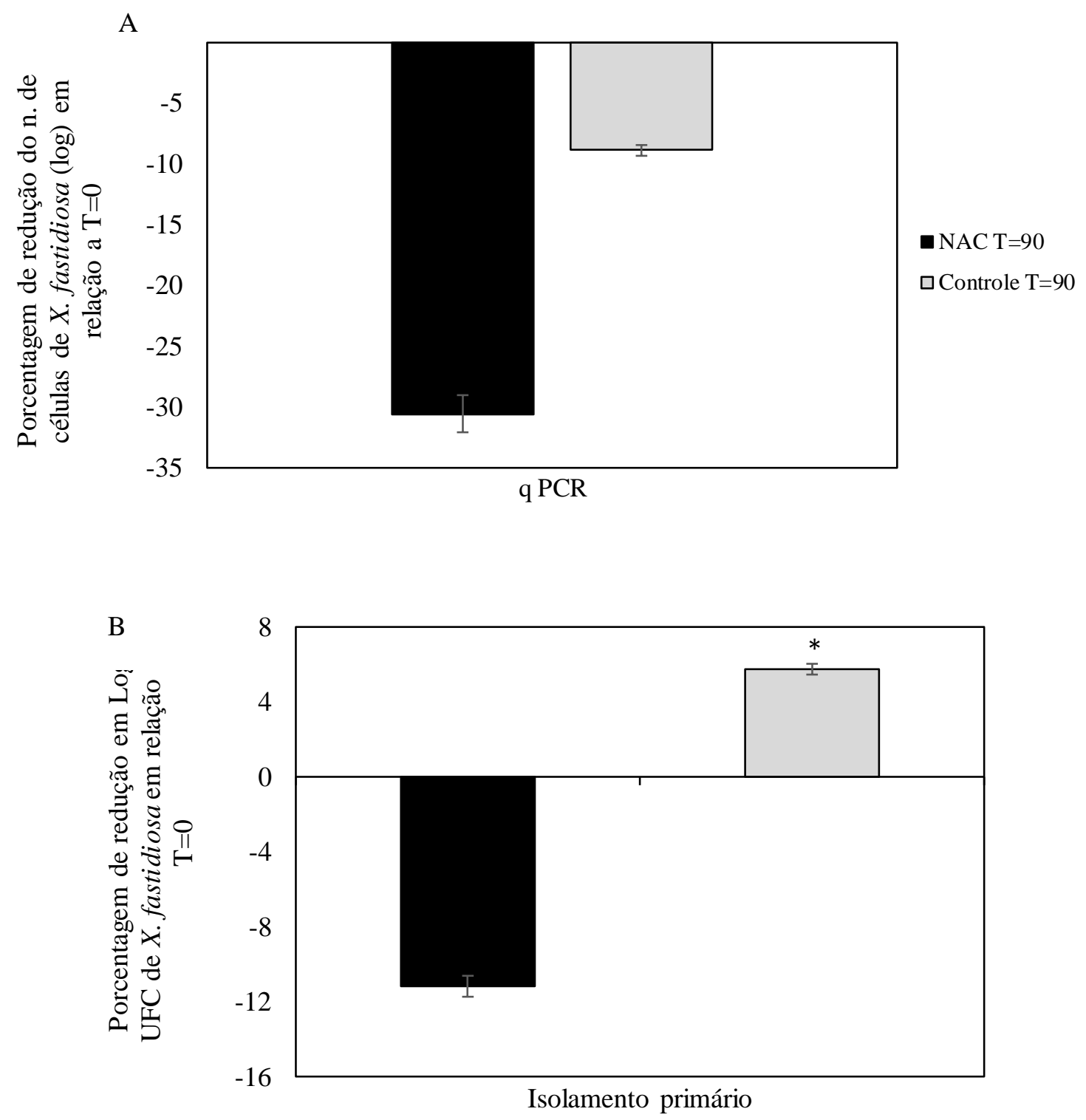

Figura 8. Redução percentual da população (convertida em log) de X. fastidiosa em plantas cítricas tratadas com N-Acetilcisteína (NAC) ou não (Controle) aos 90 dias após o tratamento (T=90) em relação ao momento anterior ao tratamento $(\mathrm{T}=0)$. A. Quantificação da bactéria por qPCR; $\mathbf{B}$. Quantificação do número de número de unidades formadoras de colônias (UFC) por isolamento primário em meio de cultura. As barras representam o erro padrão da média ( $\mathrm{n}=6$ plantas). * Indica diferença estatística entre os tratamentos de acordo com a Anova $(\mathrm{p}<0,05)$.

A eficiência de aquisição média (\%) para adultos de $M$. leucomelas confinados sobre plantas tratadas com NAC no tempo final $(\mathrm{T}=90)$ foi de $45,2 \%$ e, quando comparada ao tempo inicial $(\mathrm{T}=0)(50,1 \%)$, não apresentou diferença estatística $(\mathrm{z}=-1,311 ; \mathrm{p}=0,190)$. Para aqueles insetos que se alimentaram nas plantas pertencentes ao controle no $\mathrm{T}=90$, a eficiência de aquisição foi de 19,5\%, não diferindo em relação ao $\mathrm{T}=0$ ( $\mathrm{z}=-0,182 ; \mathrm{p}=0,855)$ (Figura 9). 


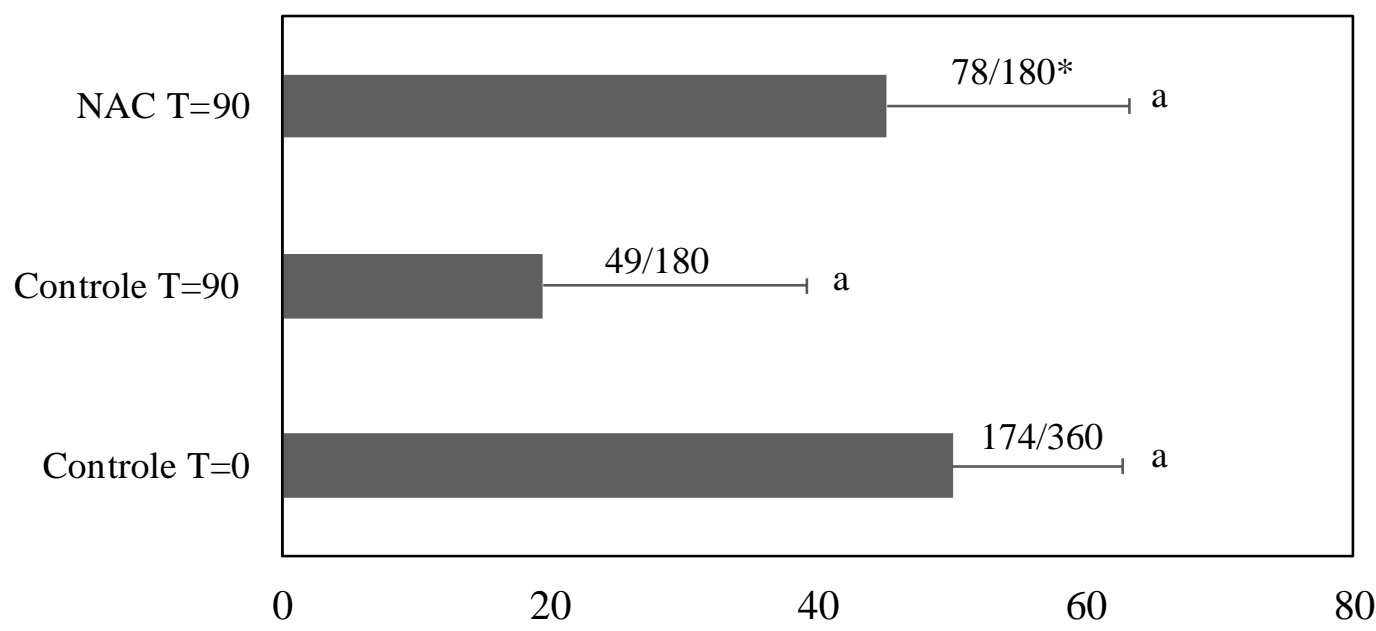

Porcentagem média de aquisição (\%)

Figura 9. Eficiêcia média de aquisição de X. fastidiosa por adultos de $M$. leucomela confinados por 48 h em plantas-fonte tratadas com N-Acetilcisteína (NAC) ou não (Controle) nos tempos T=0 e T=90. Médias seguidas de mesma letra não diferem entre si pela análise de deviance $(\mathrm{p} \leq 0,05)$. As barras representam o erro padrão da média. *Proporção de insetos positivos para a bactéria por qPCR em relação ao número total testado.

Para os dados de eficiência de transmissão de $X$. fastidiosa para plantas-teste de $C$. roseus por insetos submetidos previamente ao PAA de $48 \mathrm{~h}$ em plantas-fonte tratadas ou não com NAC, não foram observadas diferenças significativas entre as avaliações em $T=0$ e $T=90$ para o controle $(z=-1,404 ; p=0,16)$, ou entre plantas tratadas $(T=90)$ e plantas do controle $(T=0)$ $(\mathrm{z}=-0,977 ; \mathrm{p}=0,328)$ (Tabela 1). A mortalidade média dos insetos ao final do PAI foi de 35,77 $\%$ no $\mathrm{T}=0$ e de $13,96 \%$ no $\mathrm{T}=90$.

Tabela 1. Eficiência de transmissão de X. fastidiosa por adultos de $M$. leucomelas para plantas-teste de Catharantus roseus após um período de acesso à aquisição (PAA) de $48 \mathrm{~h}$ em plantas-fonte (Citrus sinensis) da bactéria que foram tratadas com N-Acetilcisteína (NAC) ou não (Controle).

\begin{tabular}{lcclcl}
\hline Tratamento $^{\mathbf{1}}$ & $\begin{array}{c}\text { Total de plantas }^{\text {testadas }} \\
\text { Controle } \mathrm{T}=90\end{array}$ & $\begin{array}{c}\text { Plantas infectadas } \\
(\boldsymbol{\%})\end{array}$ & $\begin{array}{c}\text { Transmissão por indivíduo }^{\mathbf{3}} \\
(\boldsymbol{\%})\end{array}$ & \\
\hline NAC T $=90$ & 60 & $2,0 \pm 3,0$ & $\mathrm{a}^{4}$ & $0,6 \pm 0,9$ & $\mathrm{a}$ \\
Controle $\mathrm{T}=0$ & 120 & $4,8 \pm 6,6$ & $\mathrm{a}$ & $1,6 \pm 2,3$ & $\mathrm{a}$ \\
\end{tabular}

${ }^{1}$ PAA foi realizado antes $(\mathrm{T}=0)$ ou após 90 dias $(\mathrm{T}=90)$ do tratamento das plantas-fonte, seguido de um período de acesso à inoculação de $72 \mathrm{~h}$ em plantas-teste de $C$. roseus;

${ }^{2}$ Porcentagem de plantas positivas para $X$. fastidiosa por qPCR;

${ }^{3}$ Transmissão por indivíduo estimada de acordo com Swallow (1985);

${ }^{4}$ Médias seguidas pela mesma letra na coluna não diferem entre si pela análise de deviance $(\mathrm{p} \leq 0,05)$. 


\subsection{Avaliação do efeito do NAC na transmissão de $X$. fastidiosa após a aquisição da bactéria pelo vetor}

A porcentagem média de adultos de $M$. leucomelas que se mantiveram positivos para a bactéria após a alimentação em plantas cítricas mantidas em soluções nutritivas foi semelhante entre os tratamentos (com NAC e sem NAC), nos diferentes períodos de exposição $(\mathrm{F}=0,153$; $\mathrm{gl}=1 ; \mathrm{p}=0,85)($ Figura 10).

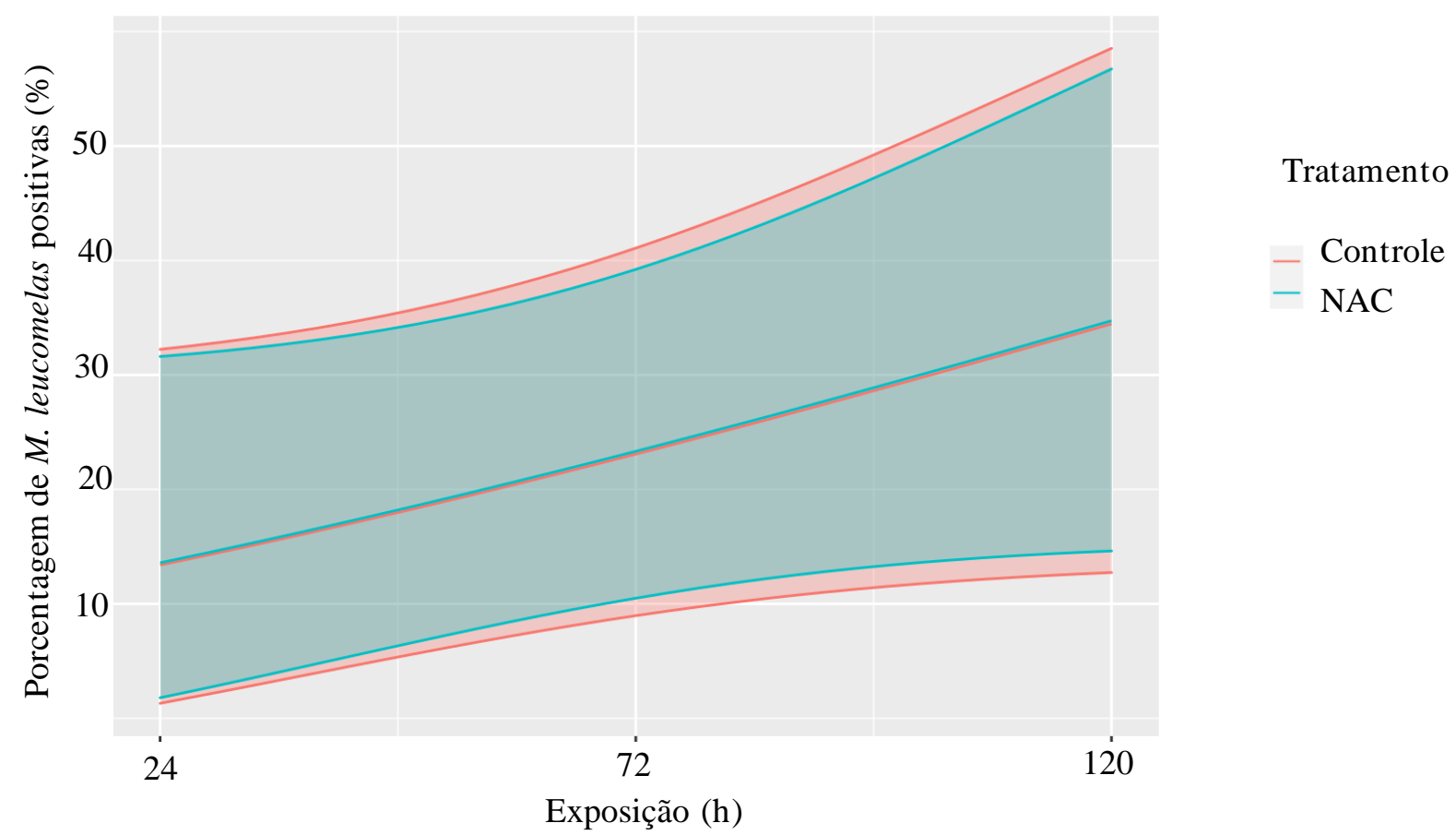

Figura 10. Porcentagem média de adultos de M. leucomelas positivos para X. fastidiosa por qPCR, agrupados após diferentes períodos de exposição $(24,72$ e $120 \mathrm{~h})$ em plantas cítricas sadias tratadas com N-Acetilcisteína (NAC) ou não (Controle). As linhas internas do gráfico referem-se à curva ajustada de regressão (quatro ensaios) da porcentagem de insetos positivos para bactéria em função do período de exposição para o tratamento controle (linha vermelha) e ao NAC (linha azul). A região colorida, delimitada pelas linhas das extremidades, corresponde a banda de confiança de $95 \%$ para proporção estimada de insetos positivos em função da exposição. Os insetos foram submetidos a um período de acesso à aquisição da bactéria em dieta artificial de $6 \mathrm{~h}$ antes da exposição às plantas tratadas. Não houve efeito dos fatores experimentais a 5\% de significância pela análise de deviance.

A absorção média total da solução nutritiva pelas plantas cítricas foi calculada com os valores medidos nos 7 dias iniciais do tratamento $(168 \mathrm{~h})$ somados às horas correspondentes a cada tratamento. Não foram observadas diferenças entre os tratamentos com NAC e sem NAC embora a absorção aumentou gradativamente em períodos mais longos de exposição $(\mathrm{F}=1,15$; $\mathrm{gl}=1 ; \mathrm{p}=0,294)$. 
As médias obtidas para os diferentes períodos de exposição foram diferentes ( $\mathrm{F}=10,10$; $\mathrm{gl}=2 ; \mathrm{p}>0,05)$. A absorção média dos dois tratamentos (com e sem NAC) por período de exposição, em $\mathrm{mL}$, para o tratamento de $24 \mathrm{~h}$ foi de $116,88 \pm 8,35$, para o de $72 \mathrm{~h}$ foi de 123,78 $\pm 4,17$ e, por último para o de 120 h foi de 137,15 $\pm 13,64$ (Figura 11).

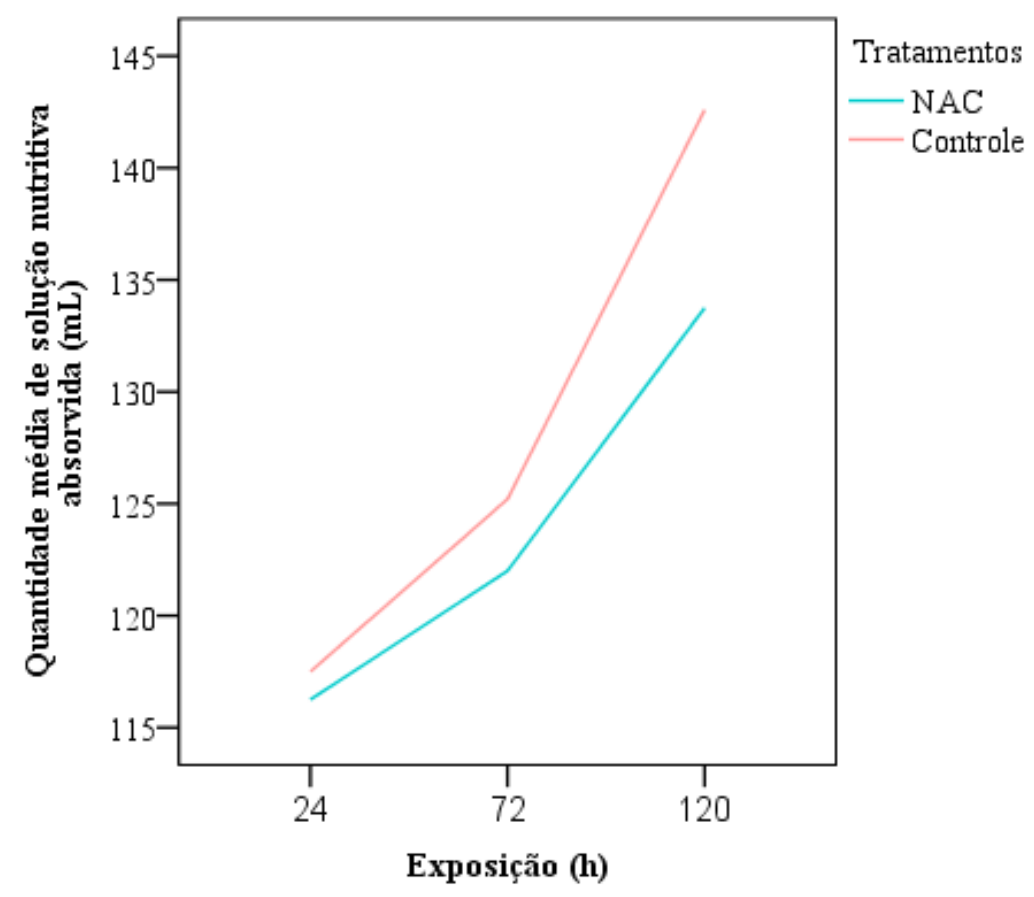

Figura 11. Quantidade média de solução nutritiva contendo N-Acetilcisteína (NAC) ou não (Controle), que foi absorvida pelas plantas cítricas em vasos de Leonard nos diferentes períodos de exposição $(24,72$ e $120 \mathrm{~h})$. As médias correspondem às quantidades iniciais absorvidas durante o prétratamento $(168 \mathrm{~h})$ somadas aos volumes absorvidos nos sucessivos períodos.

Não houve diferença nas taxas de transmissão de $X$. fastidiosa para plantas-teste de $C$. roseus entre indivíduos de $M$. leucomelas que foram alimentados por diferentes períodos em plantas cítricas tratadas ou não com NAC, após a aquisição da bactéria em dieta artificial (F= 1,09; $\mathrm{gl}=1 ; \mathrm{p}=0,34)$ (Tabela 2). 
Tabela 2. Eficiência de transmissão de X. fastidiosa por adultos de $M$. leucomelas expostos por diferentes períodos a plantas sadias de Citrus sinensis tratadas com N-Acetilcisteína (NAC) ou não (Controle), após aquisição da bactéria em dieta artificial.

\begin{tabular}{|c|c|c|c|c|c|}
\hline Tratamento $^{1}$ & $\begin{array}{c}\text { Horas de } \\
\text { exposição ao } \\
\text { tratamento }^{2}\end{array}$ & $\begin{array}{l}\text { No. total de } \\
\text { plantas-teste } \\
\text { inoculadas }\end{array}$ & $\begin{array}{c}\text { Plantas-teste } \\
\text { infectadas }^{3}(\%)\end{array}$ & $\begin{array}{c}\text { Transmissão } \\
\text { indivíduo }\end{array}$ & $\begin{array}{l}\text { por } \\
\%)\end{array}$ \\
\hline \multirow{3}{*}{ NAC } & 24 & 25 & $8,0 \pm 2,0$ & $2,7 \pm 0,7$ & $a^{5}$ \\
\hline & 72 & 18 & $28,5 \pm 7,6$ & $10,5 \pm 2,6$ & $\mathrm{a}$ \\
\hline & 120 & 16 & $18,1 \pm 5,4$ & $6,4 \pm 1,8$ & $\mathrm{a}$ \\
\hline \multirow{3}{*}{ Controle } & 24 & 25 & $12,0 \pm 2,4$ & $4,1 \pm 0,8$ & $\mathrm{a}$ \\
\hline & 72 & 14 & $5,5 \pm 1,3$ & $1,8 \pm 0,4$ & $\mathrm{a}$ \\
\hline & 120 & 11 & 0 & 0 & $\mathrm{a}$ \\
\hline
\end{tabular}

${ }^{1}$ Seedlings sadios de C. sinensis foram tratados previamente por 7 dias $(168 \mathrm{~h})$ com NAC ou não (Controle);

${ }^{2}$ Após um período de $6 \mathrm{~h}$ de acesso à aquisição de $X$. fastidiosa em dieta artificial, seguido de $24 \mathrm{~h}$ de alimentação em plantas de $V$. condensata, as cigarrinhas foram expostas aos seedlings sadios de $C$. sinensis tratados ou não com NAC. Em seguida, os insetos foram transferidos para um período de acesso à inoculação de $72 \mathrm{~h}$ em plantas sadias de Catharanthus roseus (planta-teste), em grupos de três indivíduos por planta;

${ }^{3}$ Porcentagem média de plantas-teste de $C$. roseus que foram positivas para X. fastidiosa por qPCR, em quatro repetições do experimento. Em cada repetição foram inoculadas 1 a 7 plantas-teste;

${ }^{4}$ Probabilidade de transmissão por indivíduo de M. leucomelas, estimada de acordo com Swallow (1985);

${ }^{5}$ Médias seguidas pela mesma letra na coluna não diferem entre si pela análise de deviance $(\mathrm{p} \leq 0,05)$.

\subsection{Avaliação da transmissão de $X$. fastidiosa para plantas-teste sadias, previamente tratadas ou não com NAC}

A eficiência de aquisição média dos 180 indivíduos (três ensaios) submetidos ao PAA em plantas cítricas infectadas por $X$. fastidiosa foi de $26,2 \pm 13,8 \%$.

Com relação à eficiência de transmissão de $X$. fasdiosa para $C$. roseus por indivíduo de M. leucomelas, não foram observadas diferenças significativas entre o tratamento constituído por plantas-teste de $C$. roseus que receberam NAC e o tratamento com plantas que não receberam NAC $(\mathrm{z}=-0,908 ; \mathrm{p}=0,36)$ (Tabela 3$)$. Os insetos confinados sobre plantas de $C$. roseus tratadas com NAC transmitiram com 1,9\% de eficiência, e aqueles confinados sobre plantas-teste não tratadas com NAC transmitiram com eficiência de 4,1\%. 
Tabela 3. Eficiência de transmissão de X. fastidiosa por adultos de M. leucomelas para plantas-teste de Catharanthus roseus tratadas com N-Acetilcisteína (NAC) ou não (Controle).

\begin{tabular}{ccccc}
\hline Tratamento $^{1}$ & $\begin{array}{c}\text { No. total de } \\
\text { plantas-teste } \\
\text { inoculadas }\end{array}$ & Plantas-teste infectadas $^{2}$ (\%) & Transmissão por indivíduo $^{\mathbf{3}}$ (\%) \\
\hline NAC & 30 & $5,6 \pm 4,7$ & $1,9 \pm 1,6$ & $\mathrm{a}^{4}$ \\
Controle & 30 & $12,0 \pm 7,5$ & $4,1 \pm 2,5$ & $\mathrm{a}$ \\
\hline
\end{tabular}

${ }^{1}$ Após um período de acesso à inoculação de $48 \mathrm{~h}$ em planta cítrica infectada por $X$. fastidiosa, os insetos foram submetidos à um período de acesso à inoculação de $72 \mathrm{~h}$ em plantas sadias de C. roseus (3 insetos por planta-teste) previamente tratadas ou não com NAC;

${ }^{2}$ Porcentagem média de plantas-teste (10 plantas inoculadas por ensaio) que foram positivas para $X$. fastidiosa por qPCR, em três ensaios conduzidos;

${ }^{3}$ Taxas de transmissão por um único inseto estimadas de acordo com Swallow (1985);

${ }^{4}$ Médias seguidas pela mesma letra na coluna não diferem entre si pela análise de deviance $(\mathrm{p} \leq 0,05)$.

Houve diferença entre os tratamentos em mortalidade de cigarrinhas no final das $72 \mathrm{~h}$ do PAI $(z=-2,315 ; p=0,020)$. A probabilidade de mortalidade foi mais baixa em cigarrinhas que se alimentaram em plantas-teste de C. roseus tratadas com NAC (1\%) do que em cigarrinhas confinadas sobre plantas-teste sem NAC (10\%).

\subsection{Comportamento alimentar de $P$. spumarius em plantas de $S$. oleraceus tratadas com NAC (formulação granulada com fertilizante húmico)}

O comportamento alimentar do vetor $P$. spumarius foi semelhante em plantas tratadas e não tratadas com NAC. As variáveis não sequenciais e sequenciais de EPG analisadas tiveram efeito dos tratamentos, mas as diferenças foram observadas apenas nas plantas que receberam aplicação do inseticida imidacloprid em comparação com os tratamentos com e sem NAC (Pillai trace $=2,564 ; \mathrm{p}<0,05)($ Tabela 4 e 5) (Apêndice A). Não foram observadas diferenças entre machos e fêmeas (Pillai trace $=0,754 ; \mathrm{p}=0,747$ ).

Quanto às variáveis não sequenciais, houve diferença em número médio de eventos por inseto (NWEI) para as formas de onda $\mathrm{Xc}, \mathrm{Xi}, \mathrm{N}$ e $\mathrm{R}$, entre insetos alimentados em plantas tratadas com inseticida e aqueles mantidos em plantas tratadas com e sem NAC (Tabela 4). Analisando-se a duração média de uma determinada forma de onda (WDI), observaram-se diferenças para np, Xi e R. Os resultados descritos focaram naquelas variáveis que têm influência sobre aquisição de $X$. fastidiosa.

A duração média da forma de onda 'np' (WDI np) foi diferente entre os tratamentos (F= $53,6 ; \mathrm{gl}=2 ; \mathrm{p}<0,01)$. Insetos que se alimentaram em plantas tratadas com inseticida passaram mais tempo realizando o comportamento de não-prova $(284,3 \pm 17,0 \mathrm{~min})$ do que aqueles que 
se alimentaram em plantas tratadas com NAC (63,0 $\pm 16,6 \mathrm{~min})$ ou sem NAC (91,5 $\pm 16,9 \mathrm{~min})$. Já o oposto foi observado em relação à duração (WDI) de Xi (ingestão de xilema), uma vez que os insetos que se alimentaram nas plantas tratadas com inseticida passaram menos tempo ingerindo seiva do xilema $(37,7 \pm 8,5 \mathrm{~min})$ do que insetos que se alimentaram em plantas tratadas com NAC $(161,9 \pm 17,0 \mathrm{~min})$ e sem NAC $(146,1 \pm 16,6 \mathrm{~min})(\mathrm{F}=11,57 ; \mathrm{gl}=2 ; \mathrm{p}<$ 0,01) (Figura 12-A).

O número médio (NWEI) de Xi diferiu entre os tratamentos, tendo em vista que os insetos que se alimentaram em plantas tratadas com inseticida realizaram menor número de $\mathrm{Xi}$ (ingestão de seiva do xilema) $(2,2 \pm 0,6)$ quando comparados com aqueles que se alimentaram em plantas tratadas com NAC $(9,9 \pm 1,1)$ e sem NAC $(6,9 \pm 0,9)(F=13,5 ; \mathrm{gl}=2 ; \mathrm{p}<0,01)$ (Figura 12-B).

No que diz respeito às variáveis não sequenciais, houve diferenças em número de provas com ingestão e número de provas com ingestão maior que 10 minutos entre os tratamentos e a partir da MANOVA, optou-se por testar as variáveis individualmente.

Foram testadas individualmente aquelas variáveis caracterizadas como importantes para aquisição e transmissão de $X$. fastidiosa, tais como: duração da ingestão de seiva do xilema (Xi WDI), número de provas com ingestão e número de provas com ingestão maior que 10 minutos. Com relação ao WDI Xi, houve diferença $(z=-5,70 ; p<0,01)$ entre os tratamentos com NAC $(161,94 \pm 17,02 \mathrm{~min})$ vs. inseticida $(37,75 \pm 8,48 \mathrm{~min})$ e sem NAC $(146,10 \pm 16,59 \mathrm{~min})$ vs. inseticida $(z=-5,44 ; p<0,01)$. Não foram observadas diferenças entre os tratamentos com NAC vs. sem NAC $(z=0,46 ; p=0,89)$ (Figura 13-A).

Com relação ao número de provas com ingestão no xilema $(\mathrm{Xi})$ também foram observadas diferenças entre os tratamentos $(\mathrm{F}=7,70 ; \mathrm{gl}=2 ; \mathrm{p}<0,01)$. Insetos expostos à alimentação em plantas tratadas com inseticida realizaram em média menos provas $(1,18 \pm$ $0,12)$ que atingiram $\mathrm{Xi}$, do que aqueles insetos postos em plantas tratadas com $\operatorname{NAC}(2,59 \pm$ $0,20)(\mathrm{t}=-4,47 ; \mathrm{gl}=2 ; \mathrm{p}=0,001)$ e sem NAC $(2,68 \pm 0,24)(\mathrm{t}=-4,82 ; \mathrm{gl}=2 ; \mathrm{p}<0,01)$. Não houve diferença no número de provas que atingiram $\mathrm{Xi}$ entre os tratamentos com NAC e sem NAC $(\mathrm{t}=-0,213 ; \mathrm{gl}=2 ; \mathrm{p}=0,97)$ (Figura 13-B).

Com relação ao número de provas com ingestão de xilema superior a 10 minutos $(\mathrm{Xi}>$ $10 \mathrm{~min})$, foram observadas diferenças significativas entre os tratamentos $(\mathrm{F}=5,80 ; \mathrm{gl}=2 ; \mathrm{p}<$ $0,01)$. A média para o tratamento inseticida $(0,68 \pm 0,12)$ foi inferior $(t=-4,276 ; g l=2 ; p<0,01)$ àquela obtida para insetos que se alimentaram em S. oleraceus tratados com NAC $(1,77 \pm 0,18)$. A média em plantas tratadas com inseticida também foi inferior $(\mathrm{t}=-3,85 ; \mathrm{gl}=2 ; \mathrm{p}<0,01)$ à 
observada em plantas sem NAC $(1,68 \pm 0,24)$. Não houve diferença $(t=0,558 ; g l=2 ; p=0,84)$ entre os tratamentos com NAC e sem NAC (Figura 13-C). 


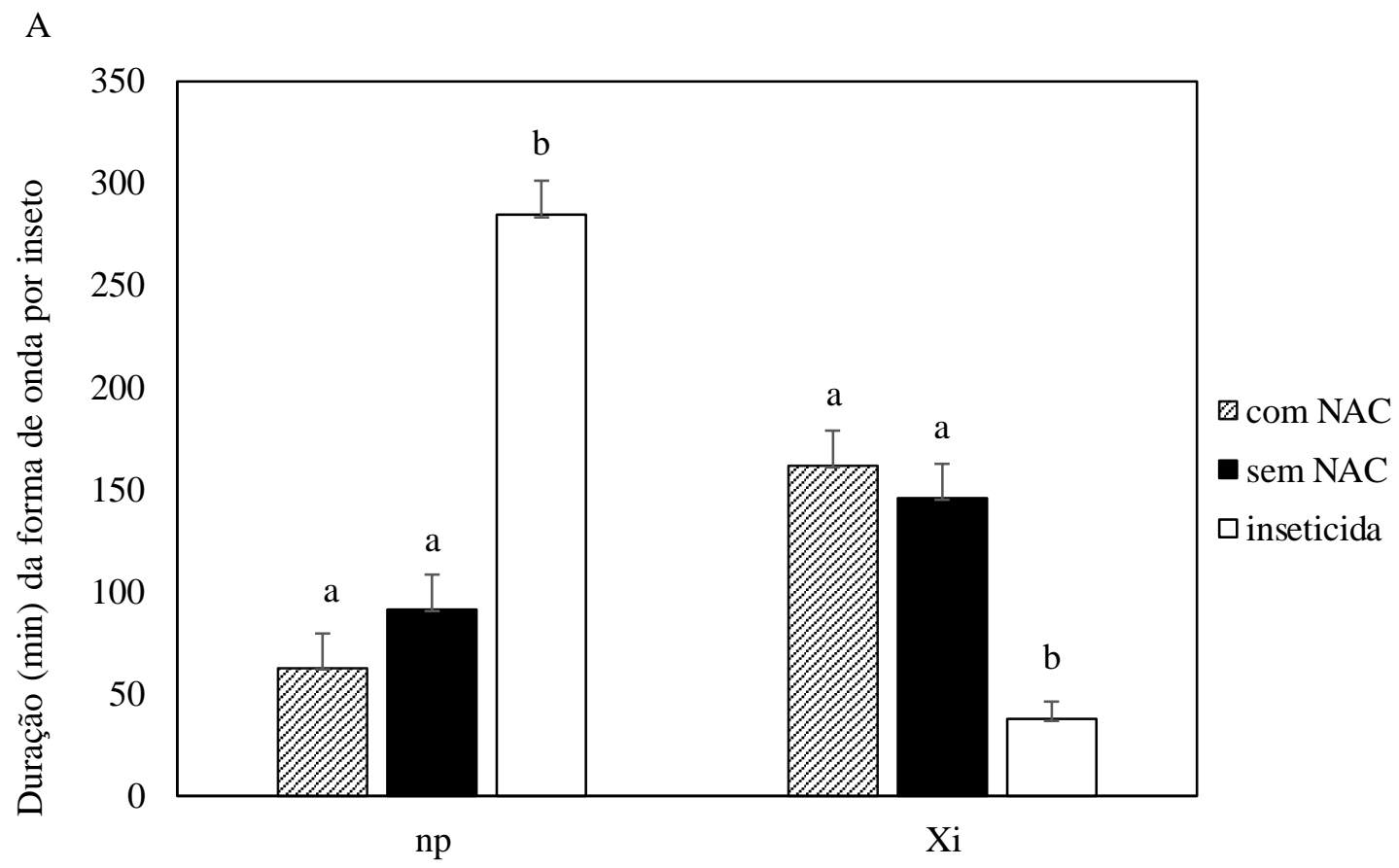

B

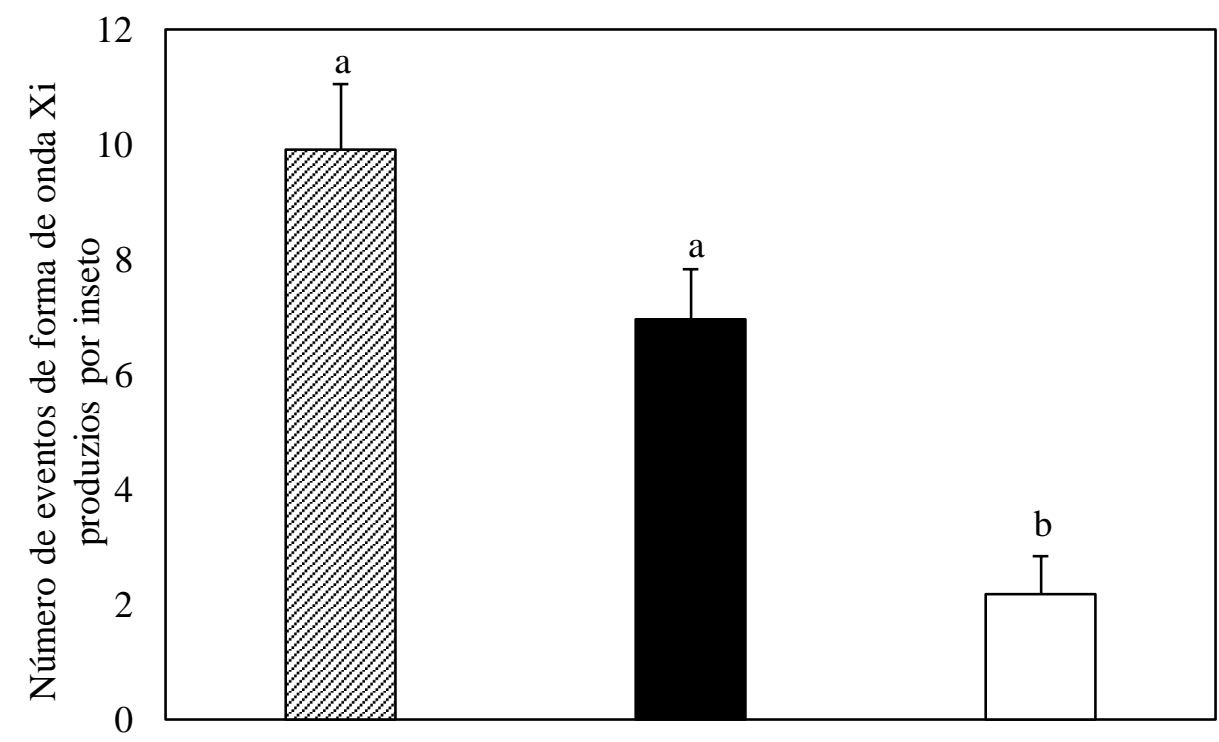

Figura 12. Variáveis não sequenciais de EPG (Média \pm EPM) empregadas na avaliação do comportamento alimentar de adultos de $P$. spumarius (machos e fêmeas) em plantas de $S$. oleraceus tratadas com NAC $(n=22)$, sem NAC $(n=25)$ ou inseticida imidacloprid $(n=22)$. A. Duração da forma de onda (min) por inseto (WDI) B. Número de eventos de forma de onda Xi produzidos por inseto (NWEI). Médias identificadas com a mesma letra não diferem estatisticamente entre si pela Anova com $\mathrm{p} \leq 0,05$. 
Tabela 4. Variáveis não sequenciais de comportamento alimentar de $P$. spumarius em plantas de $S$. oleraceus tratadas com fertilizante húmico com ou sem NAC, ou com inseticida imidacloprid, durante $6 \mathrm{~h}$ de registro de electrical penetration graphs (EPG).

\begin{tabular}{|c|c|c|c|c|c|c|c|c|}
\hline \multirow{2}{*}{ Forma de onda de EPG } & \multicolumn{4}{|c|}{ NWEI $^{\mathrm{b}}$} & \multirow{2}{*}{$\mathrm{P}^{\mathrm{d}}$} & \multicolumn{2}{|l|}{$\mathrm{WDI}^{\mathrm{c}}$} & \multirow[b]{2}{*}{$\mathrm{p}$} \\
\hline & Planta & $\mathrm{PPW}^{\mathrm{a}}$ & média \pm EPM (min-max) & & & média \pm EPM (min-max) & & \\
\hline \multirow{3}{*}{ np } & NAC & $22 / 22$ & $8,4 \pm 1,4(2-28)$ & $\mathrm{a}$ & \multirow{3}{*}{0,58} & $63,0 \pm 16,6(3,6-209,5)$ & $\mathrm{a}$ & \multirow{3}{*}{$<0,01$} \\
\hline & sem NAC & $25 / 25$ & $9,6 \pm 1,2(1-26)$ & $\mathrm{a}$ & & $91,5 \pm 16,9(0,2-307,6)$ & $\mathrm{a}$ & \\
\hline & Inseticida & $22 / 22$ & $7,4 \pm 1,2(3-29)$ & $\mathrm{a}$ & & $284,3 \pm 17,0(24,2-356,2)$ & $\mathrm{b}$ & \\
\hline \multirow{3}{*}{$\mathrm{C}$} & NAC & $22 / 22$ & $13,3 \pm 2,1(2-38)$ & $\mathrm{a}$ & \multirow{3}{*}{0,09} & $29,5 \pm 12,1(5,5-139,9)$ & $\mathrm{a}$ & \multirow{3}{*}{0,08} \\
\hline & sem NAC & $25 / 25$ & $13,1 \pm 1,7(2-33)$ & $\mathrm{a}$ & & $25,0 \pm 3,4(3,1-55,6)$ & $\mathrm{a}$ & \\
\hline & Inseticida & $22 / 22$ & $7,9 \pm 1,2(2-29)$ & $\mathrm{a}$ & & $17,3 \pm 3,00(2,8-57,4)$ & $\mathrm{a}$ & \\
\hline \multirow{3}{*}{$\mathrm{Xc}$} & NAC & $22 / 22$ & $3,1 \pm 0,3(0-6)$ & $\mathrm{a}$ & \multirow{3}{*}{$<0,01$} & $2,1 \pm 0,6(0-15,1)$ & $\mathrm{a}$ & \multirow{3}{*}{0,26} \\
\hline & sem NAC & $25 / 25$ & $2,7 \pm 0,3(1-7)$ & $\mathrm{a}$ & & $2,4 \pm 0,4(0,2-8,5)$ & $\mathrm{a}$ & \\
\hline & Inseticida & $18 / 22$ & $1,1 \pm 0,1(0-3)$ & $\mathrm{b}$ & & $1,2 \pm 0,3(0-5,7)$ & $\mathrm{a}$ & \\
\hline \multirow{3}{*}{$\mathrm{Xi}$} & NAC & $22 / 22$ & $9,9 \pm 1,1(3-21)$ & $\mathrm{a}$ & \multirow{3}{*}{$<0,01$} & $161,9 \pm 17,0(45,1-333,8)$ & $\mathrm{a}$ & \multirow{3}{*}{$<0,01$} \\
\hline & sem NAC & $25 / 25$ & $6,9 \pm 0,9(1-16)$ & $\mathrm{a}$ & & $146,1 \pm 16,6(38,1-288,8)$ & $\mathrm{a}$ & \\
\hline & Inseticida & $18 / 22$ & $3,4 \pm 0,8(0-15)$ & $\mathrm{b}$ & & $37,7 \pm 8,5(0-170,5)$ & $\mathrm{b}$ & \\
\hline \multirow{3}{*}{$\mathrm{N}$} & NAC & $21 / 22$ & $6,6 \pm 0,9(0-17)$ & $\mathrm{a}$ & \multirow{3}{*}{$<0,01$} & $2,2 \pm 0,3(0-5,8)$ & $\mathrm{a}$ & \multirow{3}{*}{$<0,01$} \\
\hline & sem NAC & $23 / 25$ & $8,9 \pm 1,6(0-36)$ & $\mathrm{a}$ & & $3,4 \pm 0,6(0-14,6)$ & $\mathrm{a}$ & \\
\hline & Inseticida & $11 / 22$ & $2,2 \pm 0,6(0-9)$ & $\mathrm{b}$ & & $0,8 \pm 0,2(0-3,2)$ & $\mathrm{b}$ & \\
\hline \multirow{3}{*}{$\mathrm{R}$} & NAC & $22 / 22$ & $8,6 \pm 1,1(1-19)$ & $\mathrm{a}$ & \multirow{3}{*}{$<0,01$} & $102,8 \pm 16,6(0,7-284,0)$ & $\mathrm{a}$ & \multirow{3}{*}{$<0,01$} \\
\hline & sem NAC & $24 / 25$ & $6,2 \pm 1,1(0-22)$ & $\mathrm{a}$ & & $94,8 \pm 17,81(0-266,4)$ & $\mathrm{a}$ & \\
\hline & Inseticida & $15 / 22$ & $2,7 \pm 0,7(0-13)$ & $\mathrm{b}$ & & $19,2 \pm 7,7(0-141,2)$ & $\mathrm{b}$ & \\
\hline \multirow{3}{*}{ Número de provas } & NAC & $22 / 22$ & $8,1 \pm 1,4(3-26)$ & $\mathrm{a}$ & \multirow{3}{*}{0,37} & & & \\
\hline & sem NAC & $25 / 25$ & $9,2 \pm 1,2(1-26)$ & $\mathrm{a}$ & & & & \\
\hline & Inseticida & $22 / 22$ & $6,5 \pm 1,2(2-28)$ & $\mathrm{a}$ & & & & \\
\hline \multirow{3}{*}{ Número de provas que chegaram a $\mathrm{Xi}$} & NAC & $22 / 22$ & $2,6 \pm 0,2(1-5)$ & $\mathrm{a}$ & \multirow{3}{*}{$<0,01$} & & & \\
\hline & sem NAC & $25 / 25$ & $2,7 \pm 0,2(1-5)$ & $\mathrm{a}$ & & & & \\
\hline & Inseticida & $18 / 22$ & $1,2 \pm 0,1(0-3)$ & $\mathrm{b}$ & & & & \\
\hline \multirow{3}{*}{ Número de provas com $\mathrm{Xi}>10 \mathrm{~min}$} & NAC & $22 / 22$ & $1,8 \pm 0,2(0-3)$ & $\mathrm{a}$ & \multirow{3}{*}{$<0,01$} & & & \\
\hline & sem NAC & $23 / 25$ & $1,7 \pm 0,2(0-5)$ & $\mathrm{a}$ & & & & \\
\hline & Inseticida & $14 / 22$ & $0,7 \pm 0,1(0-2)$ & $\mathrm{b}$ & & & & \\
\hline
\end{tabular}

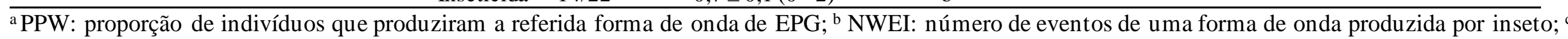
WDI: duração da forma de onda ( $\min$ ) por inseto (Backus et al. 2007); np: não prova. ${ }^{d}$ Médias seguidas pelas mesmas letras não diferem entre si pela Anova $(\mathrm{p} \leq 0,05)$. 
Tabela 5. Variáveis sequenciais de comportamento alimentar de $P$. spumarius em plantas de $S$. oleraceus tratadas com fertilizante húmico com ou sem NAC, ou com inseticida imidacloprid, durante $6 \mathrm{~h}$ de registro de electrical penetration graphs (EPG).

\begin{tabular}{|c|c|c|c|c|}
\hline Variável sequencial & Planta & Média \pm EPM (min-max) & & $\mathrm{P}^{\mathrm{a}}$ \\
\hline \multirow{3}{*}{$\begin{array}{c}\text { Tempo }(\min ) \text { entre o início } \\
\text { do EPG e a primeira Xc }\end{array}$} & NAC & $16,4 \pm 3,8(0-82,6)$ & $\mathrm{a}$ & \multirow{3}{*}{0,01} \\
\hline & sem NAC & $15,9 \pm 3,7(0,5-68,6)$ & a & \\
\hline & Inseticida & $7,0 \pm 1,5(0-30,7)$ & $\mathrm{b}$ & \\
\hline \multirow{3}{*}{$\begin{array}{l}\text { Tempo }(\min ) \text { entre o início } \\
\text { do EPG e a primeira Xi }\end{array}$} & NAC & $17,8 \pm 4,0(3,1-87,4)$ & $\mathrm{a}$ & \multirow{3}{*}{0,11} \\
\hline & sem NAC & $18,3 \pm 3,8(0,9-69,7)$ & a & \\
\hline & Inseticida & $8,7 \pm 1,7(0-31,1)$ & $\mathrm{a}$ & \\
\hline \multirow{3}{*}{$\begin{array}{c}\text { Tempo (min) entre o início } \\
\text { da primeira prova e a } \\
\text { primeira } \mathrm{Xc}\end{array}$} & NAC & $10,6 \pm 2,0(0-38,0)$ & a & \multirow{3}{*}{0,34} \\
\hline & sem NAC & $8,3 \pm 1,9(0,2-38,9)$ & $\mathrm{a}$ & \\
\hline & Inseticida & $5,2 \pm 1,0(0-13,6)$ & $\mathrm{a}$ & \\
\hline \multirow{3}{*}{$\begin{array}{c}\text { Tempo }(\min ) \text { entre o início } \\
\text { da primeira prova e a } \\
\text { primeira } \mathrm{Xi}\end{array}$} & NAC & $12,0 \pm 2,3(2,5-44,3)$ & $\mathrm{a}$ & \multirow{3}{*}{0,45} \\
\hline & sem NAC & $10,6 \pm 2,3(0,7-39,4)$ & a & \\
\hline & Inseticida & $6,9 \pm 1,2(0-31,9)$ & $\mathrm{a}$ & \\
\hline \multirow{3}{*}{$\begin{array}{c}\text { Tempo (min) entre o início } \\
\text { do EPG e a primeira } \\
\text { Xi }>10 \text { min }\end{array}$} & NAC & $60,1 \pm 17,8(3,1-304,9)$ & $\mathrm{a}$ & \multirow{3}{*}{$<0,01$} \\
\hline & sem NAC & $70,6 \pm 17,1(0-281,1)$ & a & \\
\hline & Inseticida & $19,5 \pm 8,5(0-177,8)$ & $\mathrm{b}$ & \\
\hline \multirow{3}{*}{$\begin{array}{c}\text { Tempo (min) entre o início } \\
\text { da primeira prova e a } \\
\text { primeira } \mathrm{Xi}>10 \mathrm{~min}\end{array}$} & NAC & $54,3 \pm 17,8(2,7-304,0)$ & $\mathrm{a}$ & \multirow{3}{*}{0,01} \\
\hline & sem NAC & $63,4 \pm 16,6(0-278,6)$ & a & \\
\hline & Inseticida & $17,8 \pm 7,4(0-149,4)$ & $\mathrm{b}$ & \\
\hline
\end{tabular}

${ }^{a}$ Médias seguidas pelas mesmas letras não diferem entre si pela Anova $(\mathrm{p} \leq 0,05)$. 

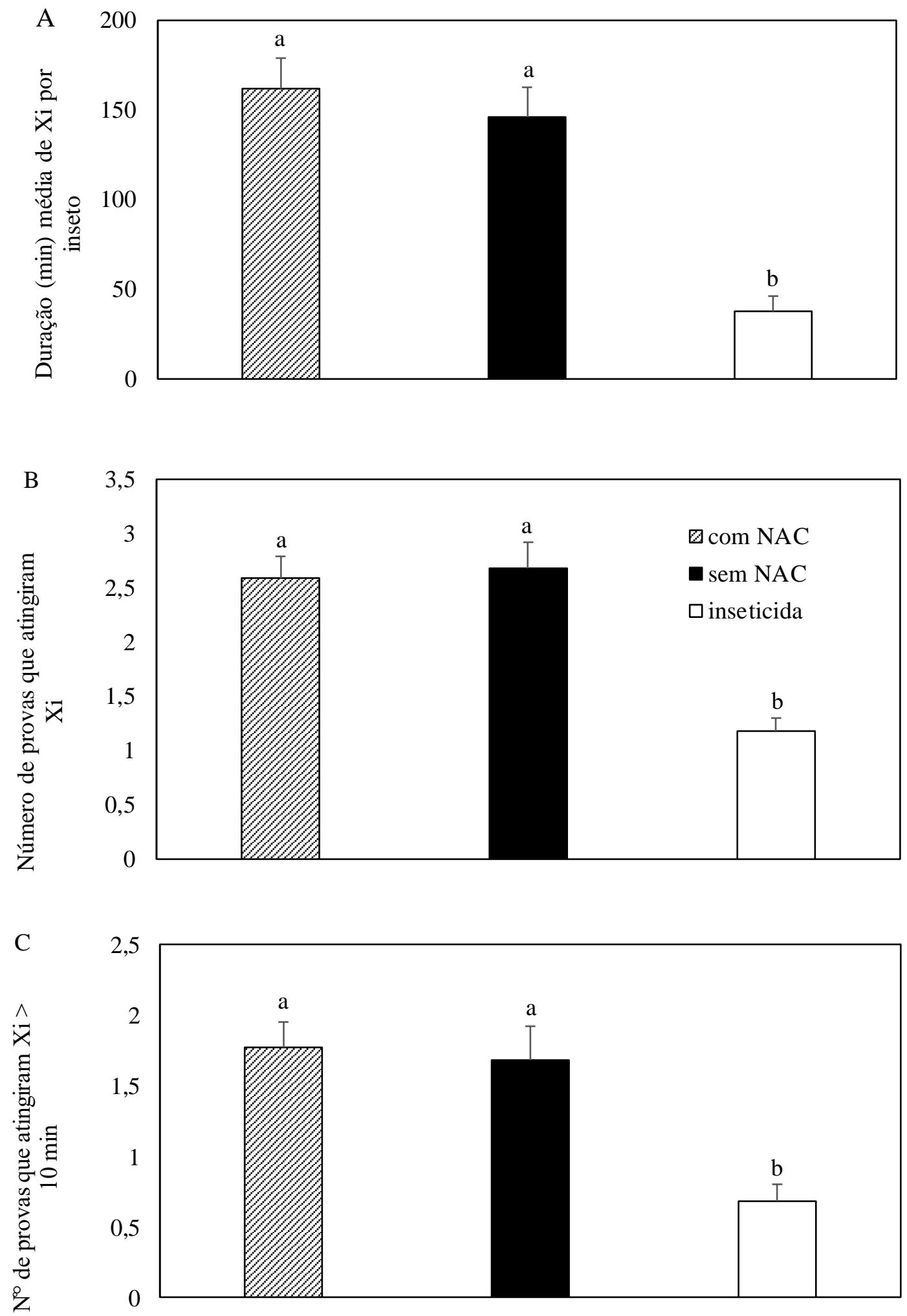

Figura 13. Variáveis não sequenciais de EPG (Média \pm EPM) de adultos de $P$. spumarius (machos e fêmeas) em plantas de $S$. oleraceus tratadas com NAC $(n=22)$, sem NAC $(n=25)$ ou inseticida imidacloprid $(\mathrm{n}=22)$, relacionadas à aquisição de X. fastidiosa. A. Duração média (min) de Xi por inseto (WDI Xi); B. Número de provas que atingiram Xi; C. Número de provas que atingiram Xi $>10$ min. Médias identificadas com a mesma letra não diferem entre si pela Anova, $p \leq 0,05$. 


\subsection{Avaliação da absorção de solução nutritiva e comportamento alimentar de $P$. spumarius em plantas de $S$. oleraceus tratadas com NAC (formulação em pó com solução nutritiva)}

Os resultados obtidos nesse experimento seguiram a tendência observada no experimento anterior. Não foram observadas diferenças no comportamento alimentar de adultos de $P$. spumarius que se alimentaram em plantas de S. oleraceus tratadas com NAC e não tratadas, com base na análise de variáveis sequenciais (WDI, NWEI) e não sequenciais de penetração estiletar (Pillai trace $=1,27 ; \mathrm{p}=0,30)($ Tabela 6 e 7).

A partir da avaliação semanal da absorção de solução nutritiva das plantas utilizadas no ensaio, a análise demonstrou que houve absorção durante o pré-tratamento de 45 dias das plantas de S. oleraceus tratadas e não tratadas com NAC. As plantas que tiveram NAC adicionado à solução nutritiva não diferiram em volume de absorção de solução nutritiva em relação às plantas sem adição de NAC $(\mathrm{z}=-2,06 ; \mathrm{p}=0,09)$, indicativo de que o NAC pode ser absorvido sem causar estresse oxidativo nas plantas de S. oleraceus. Diferenças foram observadas na absorção do controle evaporação e NAC ( $\mathrm{z}=-11,20 ; \mathrm{p}<0,01)$ e na absorção do controle evaporação e sem NAC $(z=-12,42 ; p<0,01)$ indicando que, apesar da existência da evaporação natural do líquido no vaso de Leonard, os valores de solução nutritiva absorvidos pelas plantas tratadas com solução nutritiva (NAC e sem NAC) foram maiores (Figura 14). 


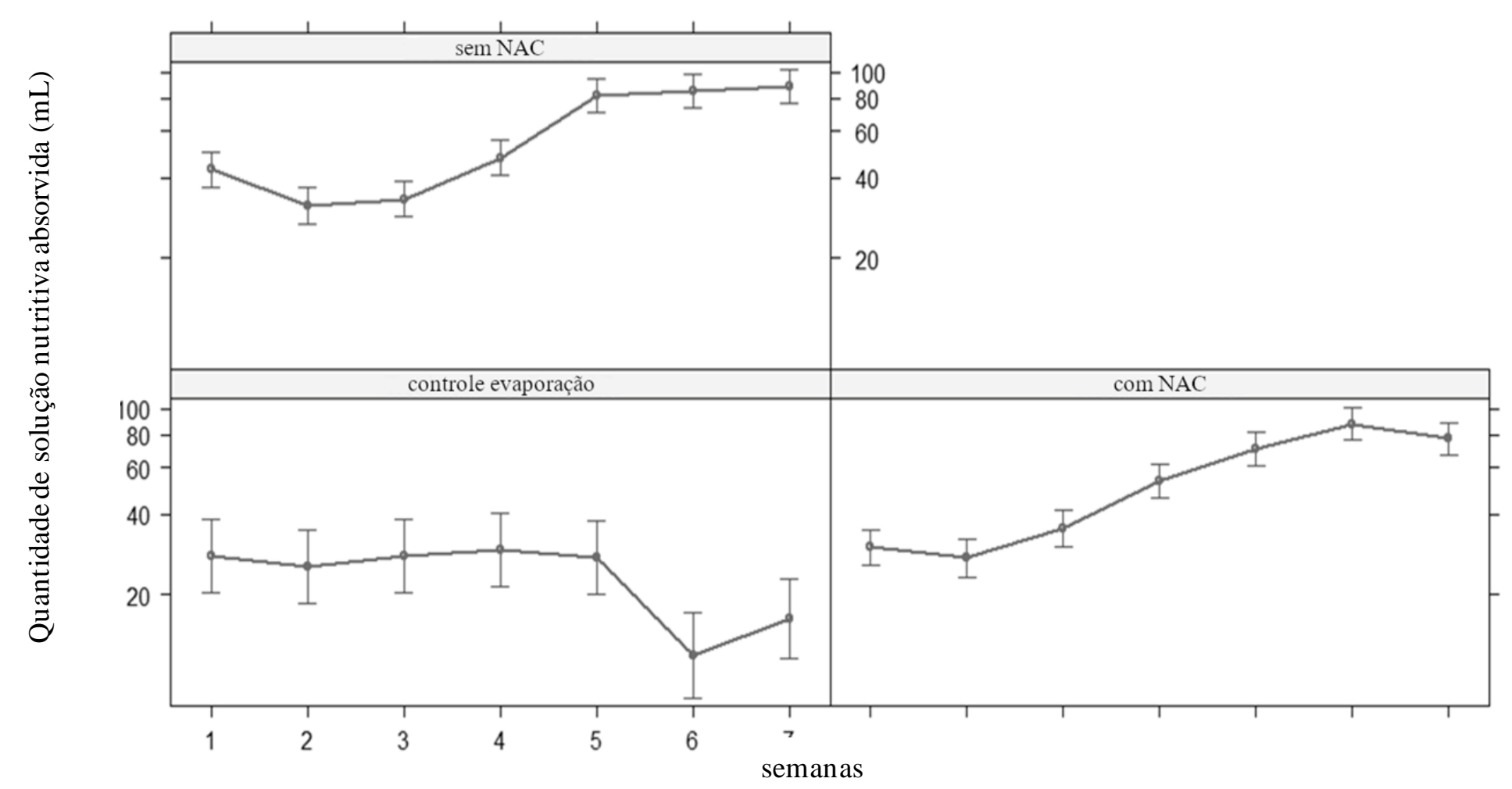

Figura 14. Volume médio ( \pm EPM) de solução nutritiva (média) absorvido por plantas de $S$. oleraceus ao longo de 7 semanas de tratamento com NAC ( $\mathrm{n}=20$ ), sem NAC $(n=20)$ e controle evaporação $(n=5)$. As linhas representam os valores obtidos a partir das médias de cada semana, plotados em relação a quantidade nutritiva absorvida. 
Tabela 6. Variáveis não sequenciais de comportamento alimentar de $P$. spumarius em plantas de $S$. oleraceus tratadas com ou sem NAC, via solução nutritiva, durante $6 \mathrm{~h}$ de registro de electrical penetration graphs (EPG).

\begin{tabular}{|c|c|c|c|c|c|c|}
\hline & & & $\mathrm{NWEI}^{\mathrm{b}}$ & Dd & WDI $^{\mathrm{c}}$ & \\
\hline Forma de onda de EPG & Planta & $\mathrm{PPW}^{\mathrm{a}}$ & média \pm EPM (min-máx) & $\mathrm{P}^{\mathrm{d}}$ & média \pm EPM (min-máx) & $\mathrm{P}$ \\
\hline \multirow{2}{*}{$\mathrm{np}$} & NAC & $20 / 20$ & $8,3 \pm 1,7(1-28)$ & \multirow{2}{*}{0,63} & $29,0 \pm 10,6(0,5-166,4)$ & \multirow{2}{*}{0,70} \\
\hline & sem NAC & $20 / 20$ & $7,3 \pm 1,3(1-17)$ & & $35,6 \pm 13,6(0,5-256,6)$ & \\
\hline \multirow{2}{*}{$\mathrm{C}$} & NAC & $20 / 20$ & $10,6 \pm 2,0(1-32)$ & \multirow{2}{*}{0,58} & $31,9 \pm 8,4(0,9-166,8)$ & \multirow{2}{*}{0,15} \\
\hline & sem NAC & $20 / 20$ & $9,3 \pm 1,3(1-20)$ & & $18,4 \pm 3,8(1,4-74,0)$ & \\
\hline \multirow{2}{*}{$\mathrm{Xc}$} & NAC & $12 / 20$ & $1,9 \pm 0,4(1-8)$ & \multirow{2}{*}{0,57} & $1,8 \pm 0,4(0,2-7,2)$ & \multirow{2}{*}{0,90} \\
\hline & sem NAC & $12 / 20$ & $2,2 \pm 0,3(1-6)$ & & $1,9 \pm 0,5(0,2-12,2)$ & \\
\hline \multirow{2}{*}{$\mathrm{Xi}$} & NAC & $20 / 20$ & $5,1 \pm 0,7(1-11)$ & \multirow[b]{2}{*}{0,42} & $253,3 \pm 24,9(22,8-354,6)$ & \multirow{2}{*}{0,80} \\
\hline & sem NAC & $20 / 20$ & $6,2 \pm 1,2(1-22)$ & & $261,7 \pm 20,6(46,7-357,4)$ & \\
\hline \multirow{2}{*}{$\mathrm{N}$} & NAC & $19 / 20$ & $13,3 \pm 1,8(0-36)$ & \multirow{2}{*}{0,71} & $5,3 \pm 1,4(1,2-28,5)$ & \multirow{2}{*}{0,46} \\
\hline & sem NAC & $18 / 20$ & $14,3 \pm 1,8(0-32)$ & & $4,2 \pm 0,5(0-9,12)$ & \\
\hline \multirow{2}{*}{$\mathrm{R}$} & NAC & $14 / 20$ & $3,1 \pm 0,7(0-10)$ & \multirow{2}{*}{0,41} & $30,3 \pm 14,9(0,00-281,7)$ & \multirow{2}{*}{0,56} \\
\hline & sem NAC & $15 / 20$ & $4,4 \pm 1,4(0-23)$ & & $42,2 \pm 13,8(0,00-176,8)$ & \\
\hline \multirow{2}{*}{ Número de provas } & NAC & $20 / 20$ & $8,2 \pm 1,7(1-28)$ & \multirow{2}{*}{0,57} & & \\
\hline & sem NAC & $20 / 20$ & $7,1 \pm 1,1(1-17)$ & & & \\
\hline \multirow{2}{*}{ Número de provas com $\mathrm{Xi}$} & NAC & $20 / 20$ & $2,1 \pm 0,3(1-6)$ & \multirow{2}{*}{0,51} & & \\
\hline & sem NAC & $20 / 20$ & $2,4 \pm 0,3(1-5)$ & & & \\
\hline \multirow{2}{*}{$\begin{array}{c}\text { Número de provas com } \mathrm{Xi}> \\
15 \mathrm{~min} \\
\end{array}$} & NAC & $20 / 20$ & $1,6 \pm 0,2(1-4)$ & \multirow{2}{*}{0,86} & & \\
\hline & sem NAC & $20 / 20$ & $1,6 \pm 0,3(1-5)$ & & & \\
\hline
\end{tabular}

a PPW: proporção de indivíduos que produziram determinados tipo de onda;

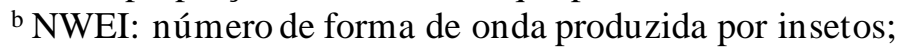

${ }^{c}$ WDI: duração de onda (min) por inseto (Backus et al. 2007); np: não prova;

${ }^{\mathrm{d}}$ Médias não diferiram estatisticamente entre si pelo teste $t(\mathrm{p}<0,05)$. 
Tabela 7. Variáveis sequenciais de comportamento alimentar de $P$. spumarius em plantas de $S$. oleraceus tratadas com ou sem NAC, via solução nutritiva, durante 6 horas de registro de electrical penetration graphs (EPG).

\begin{tabular}{|c|c|c|c|}
\hline Variável Sequencial & Planta & Média \pm EPM (min-máx) & 1 \\
\hline \multirow{2}{*}{$\begin{array}{l}\text { Tempo para a primeira Xc a partir do início do } \\
\text { EPG }\end{array}$} & NAC & $26,56 \pm 8,93(0,37-166,28)$ & \multirow{2}{*}{0,20} \\
\hline & sem NAC & $13,94 \pm 3,77(0,22-76,90)$ & \\
\hline \multirow{2}{*}{$\begin{array}{l}\text { Tempo para a primeira Xi a partir do início do } \\
\text { EPG }\end{array}$} & NAC & $22,49 \pm 5,31(0,74-97,26)$ & \multirow{2}{*}{0,30} \\
\hline & sem NAC & $15,70 \pm 3,79(1,21-78,31)$ & \\
\hline \multirow{2}{*}{$\begin{array}{c}\text { Tempo para a primeira Xc a partir do começo da } \\
\text { primeira prova }\end{array}$} & NAC & $13,98 \pm 4,48(0,19-89,75)$ & \multirow{2}{*}{0,51} \\
\hline & sem NAC & $10,03 \pm 3,58(0,11-76,04)$ & \\
\hline \multirow{2}{*}{$\begin{array}{c}\text { Tempo para a primeira Xi a partir do começo da } \\
\text { primeira prova }\end{array}$} & NAC & $21,81 \pm 7,09(0,56-126,34)$ & \multirow{2}{*}{0,22} \\
\hline & sem NAC & $11,79 \pm 3,59(1,10-77,45)$ & \\
\hline \multirow{2}{*}{$\begin{array}{l}\text { Tempo para a primeira } \mathrm{Xi}>10 \text { min a partir do } \\
\text { começo do EPG }\end{array}$} & NAC & $43,12 \pm 10,98(1,45-216,98)$ & \multirow{2}{*}{0,90} \\
\hline & sem NAC & $44,81 \pm 8,57(9,40-173,82)$ & \\
\hline \multirow{2}{*}{$\begin{array}{l}\text { Tempo para a primeira } \mathrm{Xi}>10 \text { min a partir do } \\
\text { começo do EPG }\end{array}$} & NAC & $39,29 \pm 9,73(1,71-193,02)$ & \multirow{2}{*}{0,90} \\
\hline & sem NAC & $40,90 \pm 8,78(9,28-172,65)$ & \\
\hline
\end{tabular}

${ }^{a}$ Médias não diferiram estatisticamente entre si pelo teste $t(\mathrm{p}<0,05)$. 


\section{DISCUSSÃO}

Os ensaios mostraram que a aplicação de N-acetilcisteína (NAC) em plantas cítricas infectadas por $X$. fastidiosa (plantas-fonte) não afetou a aquisição ou transmissão da bactéria por adultos da cigarrinha $M$. leucomelas no período de 90 dias após o tratamento, em relação as plantas-fonte não tratadas (controle). Os diferentes períodos de exposição (24, 72 e 120 h) dos insetos a seedlings de citros tratados com NAC, após a aquisição de X. fastidiosa em dieta artificial, não influenciou o percentual de cigarrinhas positivas para a bactéria e não afetou as taxas de transmissão para plantas sadias. Com relação as variáveis de EPG estudadas, não houve alterações no comportamento alimentar na presença ou ausência do NAC.

Neste trabalho observou-se cerca de $30 \%$ de redução na população (em $\log$ UFC/g de tecido vegetal) de $X$. fastidiosa pelo método de isolamento primário, nas plantas cítricas infectadas tratadas com NAC em relação ao tratamento controle, no mesmo período de avaliação. Muranaka et al. (2013) relatou remissão dos sintomas nos tratamentos in vivo, e redução da população de $X$. fastidiosa. Os mesmos autores ainda observaram, nos testes in vitro, redução da formação de biofilme e da produção de expolissacarídeos nos tratamentos em que o NAC foi aplicado. Resultados semelhantes também foram observadas por Picchi et al. (2016) os quais relataram redução da síntese de exopolissacarídeos, consequente redução da formação do biofilme e, diminuição da motilidade de $X$. citri nos testes in vitro. No entanto recentemente, Cattò et al. (2019) não observou redução na formação do biofilme de X. fastidiosa nos ensaios in vitro.

Nos ensaios conduzidos por Muranaka et al. (2013), a concentração de $1 \mathrm{mg} / \mathrm{mL}$ utilizada nos testes in vitro foi capaz de reduzir a adesão à superfície, formação de biofilme e produção de polissacarídeos. Já nos ensaios de Picchi et al. (2016) a concentração de $6 \mathrm{mg} / \mathrm{mL}$ associada a uma dose de cobre, principal molécula com efeito bactericida utilizada, foi capaz de matar a bactéria $X$. citri. Cattó et al. (2019) observaram que, embora tenha ocorrido diminuição na adesão à superfície em bactérias plantônicas e em biofilme, houve aumento na biomassa do biofilme no tratamento com NAC na concentração $500 \mu \mathrm{M}(0,016 \mathrm{mg} / \mathrm{ml})$. Quando aplicado no pré tratamento, o NAC não reduziu a produção de polissacarídeos. Embora no presente trabalho não foram realizados estudos in vitro, os resultados obtidos nas pesquisas anteriores fundamentam e sustentam o uso da molécula nos ensaios in vivo.

As plantas cítricas infectadas por $X$. fastidiosa e tratadas com NAC apresentaram diminuição dos sintomas após 90 dias de tratamento (com reaplicações a cada 30 dias), embora não tenha sido feita uma avaliação da severidade. Neste trabalho a aplicação do NAC associado 
a um fertilizante húmico para absorção lenta, via raiz, não diminuiu a população de $X$. fastidiosa a ponto de diferir do controle, sem aplicação do NAC. Muranaka et al. (2013), por sua vez observaram, após 3 aplicações espaçadas ( $1^{\circ}$ dia; 4 e 7 meses), redução da população bacteriana e dos sintomas da doença.

A eficiência de aquisição e transmissão pode estar relacionada à população de $X$. fastidiosa na planta-fonte, considerando que maiores populações da bactéria dentro da planta aumentam a probabilidade do inseto em adquirir o patógeno e, consequentemente, transmití-la (Hill \& Purcell 1997; Almeida et al. 2001). A concentração bacteriana de $10^{4} \mathrm{UFC} / \mathrm{g}$, resultado médio obtido por isolamento primário para as plantas-fonte tratadas com NAC, foi suficiente para possibilitar a aquisição, corroborando com o descrito anteriormente por Hill \& Purcell (1997) como a concentração mínima para aquisição pelo vetor. Embora na avaliação do tempo $\mathrm{T}=0$ as plantas apresentassem sintomas visíveis da presença da bactéria e maior população bacteriana, isso não refletiu em maiores taxas de aquisição. Isto porque, apesar dos tecidos sintomáticos com X. fastidiosa apresentarem tendência à maior título (Hill \& Purcell 1997), é preciso considerar que os insetos, quando em condição de livre escolha, preferem alimentar-se em tecidos assintomáticos (Marucci et al. 2005; Del Cid et al. 2018). Esse comportamento reduz ainda mais a probalidade de sucesso de aquisição da bactéria considerando-se, também, que a porcentagem de vasos colonizados por $X$. fastidiosa em citros é menor que em outros hospedeiros como café e ameixa (Alves et al. 2004). Apesar de não observadas diferenças na porcentagem de insetos positivos, tempos maiores de exposição ao NAC poderiam refletir em maior redução da população bacteriana dentro da planta e então, apresentar efeito negativo sobre transmissão da bactéria.

Resultados obtidos com a molécula de NAC marcada com N15 e C13 oferecida à planta através do sistema hidropônico, sugeriram que a partir de 7 dias tal molécula já se encontra nas folhas, sendo esse o motivo pelo qual adotou-se pré-tratamento de 1 semana (dados não publicados). No entanto, a forma diluída em solução nutritiva pode aumentar as chances de degradação da molécula. Para garantir a viabilidade e estimar a porcentagem de absorção, Muranaka et al. (2013) acompanharam a absorção por plantas cítricas e concluíram que em 7 dias, descontados o percentual de degradação, a planta absorveu 33\% do NAC em concentração inicial, que no estudo foi de $0,48 \mathrm{mg} / \mathrm{ml}$, possibilitando redução da população da bactéria e dos sintomas. Em concordância com esses dados, neste estudo foram utilizadas plantas sadias de citros e NAC na concentração de $0,1 \mathrm{mg} / \mathrm{ml}$, com o intuito de proporcionar a translocação da molécula na planta e, assim possibilitar o contato do NAC com o inseto, durante a alimentação. 
Levando-se em conta o percentual de degradação, a reposição da solução nutritiva com NAC foi feita aos 7 dias.

Para a taxa de aquisição em sistema artificial, a porcentagem de adultos de M. leucomelas positivas obtidas no estudo foi semelhante ao observado por Esteves et al. (2019), em cujo trabalho a porcentagem positiva para X. fastidiosa, estirpe 9 a5c, foi de $28,9 \%$. Observou-se aumento gradativo na detecção de insetos positivos, possivelmente influenciado pela multiplicação da bactéria no vetor após a aquisição, aumentando as chances de identificação através da técnica do qPCR. O mesmo foi observado por Hill e Purcell (1995a) que relataram aumento da população de X. fastidiosa em adultos de Graphocephala atropunctata (Signoret), vetor do patógeno em videira, indicando ainda que maiores quantidades bacterianas foram observadas aos 7 dias, e que após esse período não foram identificados incrementos consideráveis. Estudos comparativos recentes revelaram que há diferenças entre espécies de vetores e que a quantidade de $X$. fastidiosa dentro do estomodeu pode estar relacionada à dinâmica de fluídos nas partes bucais do inseto e da estrutura química da superfície cuticular disponível para interação da bactéria (Ranieri et al. 2020).

O processo de colonização da bactéria no estomodeu do inseto vetor envolve etapas complexas e que requerem a expressão de diferentes proteínas, mediadas pela regulação gênica. Em testes in vitro, observou-se que $X$. fastidiosa possui ao menos cinco fases distintas na formação do biofilme. Após 3 dias de crescimento inicia-se a formação do biofilme, com fase de maturação a partir do $15^{\circ}$ dia, estendendo-se até o $20^{\circ}$ dia de crescimento. Somente após o $30^{\circ}$ dia inicia-se a fase de dispersão celular (de Souza et al. 2004). O trabalho de Marchese et al. (2003), além de demonstrar que o NAC reduziu o biofilme, também indicou que a resposta do tratamento com NAC varia de acordo com a idade do biofilme. A molécula aplicada sozinha no tratamento reduziu de 20-40\% a formação do biofilme de Escherichia coli na concentração de $0,5 \mathrm{mg} / \mathrm{ml}$, e em 50-60\% com $4 \mathrm{mg} / \mathrm{ml}$. Com relação à idade do biofilme, a redução da matriz de exopolissacarídeo foi 40-50\% maior sobre o biofilme maduro (48 h para E. coli) em relação ao biofilme inicial $(5 \mathrm{~h})$. Correlacionando as informações da maturação do biofilme de $X$. fastidiosa, os dados sugerem que, assim como Cattó et al. (2019) não identificou redução na produção da matriz de polissacarídeos, neste trabalho também não foram identificadas respostas diferentes no tratamento com NAC. No entanto, a concentração de NAC usada por Cattò et al. (2019) em X. fastidiosa subsp. pauca (De Donno) foi muito menor que dose utilizada para alterar biofilme de X. fastidiosa subsp. pauca (9a5c) (bem como de outros patógenos de bactérias). Em $X$. fastidiosa 9 a 5c, foi necessário ao menos $1 \mathrm{mg} / \mathrm{ml}$ de NAC para a ruptura do biofilme, enquanto a concentração usada por Cattò et al., (2019) em X. fastidiosa De Donno foi 
o que equivalente a $0,016 \mathrm{mg} / \mathrm{mL}$. Isso representa, pelo menos 10 vezes menos NAC que a menor dose utilizada nos experimentos de Muranaka et al. (2013). Hipoteticamente, o efeito do NAC é sobre o biofilme maduro e no ensaio conduzido não houve tempo hábil para formação do biofilme maduro no inseto, assim como no trabalho de Cattó et al. (2019), no qual a avaliação foi realizada em biofilme com 3 dias de crescimento. Essa teoria pode ainda ser sustentada pelos resultados obtidos in vitro por Muranaka et al.(2013), que testou o NAC em bactérias crescidas por 14 dias. Embora as bactérias em biofilme apresentem características fisiológicas que lhe conferem maior resistência a moléculas químicas, detergentes e antibióticos em comparação às células plantônicas (Hoyle \& Costerton 1991), no caso do NAC os trabalhos sugerem que a eficiência no controle da bactéria é maior quando esta se encontra bem estabelecida em biofilme.

Estudos anteriores sugerem que uma pequena quantidade de células de X. fastidiosa é suficiente para uma transmissão eficiente por cigarrinhas (Hill \& Purcell 1995a; Cornara et al. 2016). Hill e Purcell (1995a) observaram que 100 células bacterianas, detectadas posteriormente por isolamento primário, foram suficientes para uma transmissão eficiente. Daugherty et al. (2009) também sugeriram que não há relação direta entre o sucesso na inoculação e o título bacteriano de $X$. fastidiosa dentro do inseto vetor. Os resultados dos testes de transmissão aqui relatados indicaram que foi possível detectar a presença da bactéria nas plantas-teste de C. roseus. De maneira geral e, como relatadas em diversos trabalhos, as taxas de transmissão por diversas espécies de cigarrinhas são baixas no patossistema da CVC e este acaba por ser um fator que limita inferir sobre o efeito de determinadas substâncias nesse processo de transmissão.

As taxas de transmissão individuais obtidas neste trabalho estão próximas daquelas observadas por autores que realizaram ensaios semelhantes. Yamamoto et al. (2002) obtiveram 0,5 e 0,3\% de eficiência individual de transmissão para as espécies Homalodisca ignorata (Melichar) e Acrogonia virescens (Metcalf), respectivamente. Lopes \& Krugner (2016) trabalhando com PAA de $48 \mathrm{~h}$ em plantas-fonte cítricas obtiveram taxas de transmissão individuais para C. sinensis entre 0,2-15,9\% para M. leucomelas e Bucephalogonia xanthophis (Berg). Mais recentemente, Esteves et al. (2019) obtiveram taxas de transmissão de 15,8\% para adultos de M. leucomelas a partir da aquisição em sistema artificial, superiores às taxas obtidas nos ensaios desta pesquisa, que seguiram a mesma metodologia de PAA em sachês.

Além do efeito mucolítico, a ação antioxidante do NAC também é igualmente atribuída à presença do grupo sulfidril. Os antioxidantes atuam induzindo uma série de reações de redução 
que preservam o status redox das células e possibilitam a utilização eficiente das fontes de energia para manutenção vital (Blokhina et al. 2003). Em trabalho desenvolvido recentemente com Candidatus Liberibacter asiaticus (Bergamo 2019), agente etiológico do Greening dos citros, verificou-se redução na produção do peróxido de hidrogênio nas plantas tratadas com NAC e também redução da peroxidação lipídica. Concomitantemente, o trabalho observou aumento na produção da enzima catalase, responsável por regular os níveis de radicais livres, e diminuir o estresse oxidativo da planta (Bergamo 2019).

Os resultados obtidos com o NAC sugerem que sua aplicação regular propicia melhor desenvolvimento da planta. Apesar de não indentificadas diferenças estatísticas na transmissão de $X$. fastidiosa por adultos de M. leucomelas em plantas tratadas e não tratadas com NAC, no aspecto geral, as plantas de $C$. roseus apresentaram diferenças de tamanho no tratamento sem e com NAC, aos 30 dias de tratamento. Embora não se possa concluir o efeito do NAC nas plantas sadias com os experimentos em plantas-teste aqui realizados, ensaios subsequentes utilizando plantas cultivadas podem esclarecer melhor se esse desentrave no crescimento pode refletir em diminuição da probabilidade de a bactéria conseguir multiplicar-se, formar biofilme e causar a doença.

A análise de todas as variáveis de EPG demonstrou que os insetos não alteraram seu comportamento alimentar na presença ou ausência do NAC, após o tratamento com NAC na formulação granulada. Neste trabalho a caracterização das formas de onda seguiu o descrito por Cornara et al. (2018), que por sua vez relatou semelhança entre as formas de onda produzidas por P. spumarius e as relatadas para o cicadelídeo B. xanthophis por Miranda et al. (2009). As diferenças comportamentais foram observadas apenas no controle positivo, no qual os insetos foram colocados sobre plantas tratadas com inseticidas. O Imidacloprid foi escolhido por alterar o comportamento alimentar, a partir de trabalhos que comprovaram que este inseticida é eficiente no controle de P. spumarius (Dongiovanni et al. 2018).

O tempo gasto de alimentação no xilema é uma variável previamente descrita como relacionada à aquisição de $X$. fastidiosa, e que ingestões persistentes de até 15 minutos já possibilitam a aquisição (Cornara et al. 2020). Miranda et al. (2009) concluíram, para adultos de B. xanthophis alimentando-se em $C$. sinensis, que na maior parte das $8 \mathrm{~h}$ de registros, os insetos realizaram alimentação no xilema. O mesmo foi observado no presente trabalho, no qual em ambos tratamentos com NAC e sem NAC, os insetos passaram a maior parte das 6 horas de registro, realizando ingestão em xilema. Não foram identificadas diferenças entre machos e fêmeas, tanto no tratamento com NAC e naquele sem NAC para as variáveis analisadas, embora Cornara et al. (2018) tenham relatado que fêmeas de P. spumarius passaram mais tempo 
realizando ingestão no xilema em plantas de oliveira. De acordo com o observado nos ensaios, a presença do NAC não implicaria em redução na probabilidade de aquisição da bactéria. No entanto, para elucidar a hipótese são necessários trabalhos complementares que investiguem o comportamento alimentar do vetor em plantas com a presença da bactéria $X$. fastidiosa e o tratamento com NAC. Sabe-se que a presença da bactéria colonizando o estomodeu do inseto pode dificultar o processo de ingestão continuada, como relatado por Cornara et al. (2020), e que essas alterações podem estar relacionadas com o estreitamento do canal alimentar, demandando mais esforço por parte do vetor para ingerir (Ranieri et al. 2020).

Dentre as variáveis de EPG que podem elucidar o processo de transmissão, o número de provas realizadas pelo vetor é uma delas. Jackson et al. (2008) sugeriram que a eficiência de transmissão pode estar mais relacionada com o número de provas que o inseto realizou do que com tempo de ingestão. O mesmo foi observado por Daugherty et al. (2009), que sugeriram que o sucesso na transmissão está relacionado ao número de inoculações. Neste trabalho não foram observadas diferenças no número de provas realizadas por $P$. spumarius nas plantas tratadas com NAC e sem NAC, sugerindo que numa situação em que a bactéria esteja presente não haveria diminuição das taxas de transmissão. No entanto, novas investigações envolvendo a bactéria, o NAC e o inseto vetor são necessárias para que suposições sejam feitas.

Em suma, a aplicação do NAC pode ter efeito positivo na redução de sintomas em plantas infectadas por $X$. fastidiosa, mas que nas condições aqui testadas não se refletiu em diferenças nas taxas de aquisição e transmissão de $X$. fastidiosa pelo vetor $M$. leucomelas. Levanta-se a hipótese de que períodos mais longos de tratamento com NAC sejam necessários para uma redução significativa na população bacteriana em plantas cítricas infectadas, a ponto de detectar-se algum efeito na aquisição ou transmissão. Com base nos resultados aqui obtidos, em tempos curtos de exposição ao tratamento com NAC, o uso de inseticida se mantém preconizado para impedir a transmissão da bactéria $X$. fastidiosa. 


\section{CONCLUSÕES}

- As eficiências de aquisição e de subsequente transmissão de X. fastidiosa por adultos da cigarrinha $M$. leucomelas não foram afetadas pelo tratamento de plantas-fonte da bactéria com NAC por um período de 90 dias;

- Após a aquisição de $X$. fastidiosa, a exposição por até 5 dias do inseto vetor a plantas cítricas sadias tratadas com NAC não afeta a taxa de insetos positivos para a bactéria ou a probabilidade de transmissão para plantas-teste;

- O pré-tratamento de plantas sadias de C. roseus com NAC por 30 dias não impede a sua infecção por $X$. fastidiosa após a inoculação pelo inseto vetor;

- A aplicação do NAC em plantas de $S$. oleraceus não altera o comportamento alimentar $P$. spumarius, não influenciando em variáveis de EPG relacionadas à transmissão de $X$. fastidiosa. 


\section{REFERÊNCIAS}

Aldini G, Altomare A, Baron G, et al (2018) N-Acetylcysteine as an antioxidant and disulphide breaking agent: the reasons why. Free Radic Res 52:751-762. https://doi.org/10.1080/10715762.2018.1468564

Almeida RPP, Blua MJ, Lopes JRS, Purcell AH (2005) Vector transmission of Xylella fastidiosa: Applying fundamental knowledge to generate disease management strategies. Ann Entomol Soc Am 98:775-786. https://doi.org/10.1094/PD-89-0419

Almeida RPP, Blua MJ, Lopes JRS, Purcell AH (2006) Vector Transmission of Xylella fastidiosa: Applying Fundamental Knowledge to Generate Disease Management Strategies. Ann Entomol Soc Am 98:775-786. https://doi.org/10.1603/00138746(2005)098[0775:vtoxfa]2.0.co;2

Almeida RPP, Mann R, Purcell AH (2004) Xylella fastidiosa cultivation on a minimal solid defined medium. Curr Microbiol 48:368-372. https://doi.org/10.1007/s00284-003-4219$\mathrm{x}$

Almeida RPP, Pereira EF, Purcell AH, Lopes JRS (2001) Multiplication and Movement of a Citrus Strain of Xylella fastidiosa Within Sweet Orange. Plant Dis 85:382-386. https://doi.org/10.1094/PDIS.2001.85.4.382

Almeida RPP, Purcell AH (2003) Transmission of Xylella fastidiosa to Grapevines by Homalodisca coagulata (Hemiptera: Cicadellidae). J Econ Entomol 96:264-271. https://doi.org/10.1093/jee/96.2.264

Almeida RPP, Purcell AH (2006) Patterns of Xylella fastidiosa colonization on the precibarium of sharpshooter vectors relative to transmission to plants. Ann Entomol Soc Am 99:884-890

Alves E, Marucci CR, Lopes JRS, Leite B (2004) Leaf symptoms on plum, coffee and citrus and the relationship with the extent of xylem vessels colonized by Xylella fastidiosa. $\mathrm{J}$ Phytopathol 152:291-297. https://doi.org/10.1111/j.1439-0434.2004.00843.x

Backus EA, Andrews KB, Shugart HJ, et al (2012) Salivary enzymes are injected into xylem by the glassy-winged sharpshooter, a vector of Xylella fastidiosa . J Insect Physiol 58:949959. https://doi.org/10.1016/j.jinsphys.2012.04.011

Backus EA, Cervantes FA, Guedes, R, N C, et al (2019) AC-DC electropenetrography for indepth studies of feeding and oviposition behaviors. Ann Entomol Soc Am 112:236-248. https://doi.org/10.1093/aesa/saz009

Backus EA, Cline AR, Ellerseick MR, Serrano MS (2007) Lygus hesperus (Hemiptera: Miridae) feeding on cotton: New methods and parameters for analysis of nonsequential Electrical Penetration Graph data. Ann Entomol Soc Am 100:296-310. https://doi.org/10.1603/0013-8746(2007)100[296:lhhmfo]2.0.co;2

Backus EA, Holmes WJ, Schreiber F, et al (2009) Sharpshooter X Wave: Correlation of an Electrical Penetration Graph waveform with xylem penetration supports a hypothesized mechanism for Xylella fastidiosa Inoculation. Ann Entomol Soc Am 102:847-867. https://doi.org/10.1603/008.102.0512

Backus EA, Shih HT (2020) Do sharpshooters from around the world produce the same EPG waveforms? Comparison of waveform libraries from Xylella fastidiosa (Xanthomonadales: Xanthomonadaceae) vectors Kolla paulula (Hemiptera: Cicadellidae) from taiwan and Graphocephala atropunctata. J Insect Sci 20:1-15 
Backus EA, Shugart HJ, Rogers EE, et al (2015) Direct evidence of egestion and salivation of Xylella fastidiosa suggests sharpshooters can be "flying syringes." Phytopathology 105:608-620. https://doi.org/10.1094/PHYTO-09-14-0258-R

Bergamo HAS (2019) N-acetilcisteína em plantas cítricas infectadas com Candidatus liberibacter asiaticus : efeitos no título bacteriano e no hospedeiro

Blasi F, Page C, Rossolini GM, et al (2016) The effect of N-acetylcysteine on biofilms: Implications for the treatment of respiratory tract infections. Respir Med 117:190-197. https://doi.org/10.1016/j.rmed.2016.06.015

Blokhina O, Virolainen E, Fagerstedt KV (2003) Antioxidants, oxidative damage and oxygen deprivation stress: A review. Ann Bot 91:179-194. https://doi.org/10.1093/aob/mcf118

Bové JM, Ayres AJ (2007) Etiology of three recent diseases of citrus in São Paulo state: Sudden death, variegated chlorosis and huanglongbing. IUBMB Life 59:346-354. https://doi.org/10.1080/15216540701299326

Carmo-Sousa M, Garcia RB, Wulff NA, et al (2020) Drench application of systemic insecticides disrupts probing behavior of Diaphorina citri (Hemiptera: Liviidae) and inoculation of Candidatus liberibacter asiaticus . Insects 11:1-12. https://doi.org/10.3390/insects11050314

Carmo-Sousa M, Moreno A, Garzo E, Fereres A (2014) A non-persistently transmitted-virus induces a pull-push strategy in its aphid vector to optimize transmission and spread. Virus Res 186:38-46. https://doi.org/10.1016/j.virusres.2013.12.012

Cattò C, De Vincenti L, Cappitelli F, et al (2019) Non-lethal effects of N-acetylcysteine on Xylella fastidiosa strain de donno biofilm formation and detachment. Microorganisms 7:. https://doi.org/10.3390/microorganisms7120656

Chatterjee S, Almeida RPP, Lindow S (2008) Living in two worlds: The plant and insect lifestyles of Xylella fastidiosa . Annu Rev Phytopathol 46:243-271. https://doi.org/10.1146/annurev.phyto.45.062806.094342

Coletta-Filho HD, Castillo AI, Laranjeira FF, et al (2020) Citrus Variegated Chlorosis: an overview of 30 years of research and disease management. Trop Plant Pathol 45:175-191.

Coletta-Filho HD, Pereira EO, Souza AA, et al (2007) Analysis of resistance to Xylella fastidiosa within a hybrid population of Pera sweet orange $\mathrm{x}$ Murcott tangor. Plant Pathol 56:661-668. https://doi.org/10.1111/j.1365-3059.2007.01605.x

Coletta-Filho HD, Targon MLPN, Takita MA, et al (2004) First Report of the Causal Agent of Huanglongbing (“Candidatus Liberibacter asiaticus") in Brazil. Plant Dis 88:1382-1382. https://doi.org/10.1094/pdis.2004.88.12.1382c

Coletta Filho HD, De Souza AA (2014) Advances on knowledge about citrus variegated chlorosis: an overview on different components of this pathosystem. Citrus Res Technol 35: https://doi.org/10.5935/2236-3122.20140003

Cornara D, Garzo E, Morente M, et al (2018) EPG combined with micro-CT and video recording reveals new insights on the feeding behavior of Philaenus spumarius . PLoS One 13:1-20. https://doi.org/10.1371/journal.pone.0199154

Cornara D, Marra M, Morente M, et al (2020) Feeding behavior in relation to spittlebug transmission of Xylella fastidiosa . J Pest Sci (2004). https://doi.org/10.1007/s10340-02001236-4 
Cornara D, Sicard A, Zeilinger AR, et al (2016) Transmission of Xylella fastidiosa to grapevine by the meadow spittlebug. Phytopathology 106:1285-1290. https://doi.org/10.1094/PHYTO-05-16-0202-R

Dat J, Vandenabeele S, Vranová E, et al (2000) Dual action of the active oxygen species during plant stress responses. Cell Mol Life Sci 57:779-795. https://doi.org/10.1007/s000180050041

Daugherty MP, Bosco D, Almeida RPP (2009) Temperature mediates vector transmission efficiency: Inoculum supply and plant infection dynamics. Ann Appl Biol 155:361-369. https://doi.org/10.1111/j.1744-7348.2009.00346.x

Daugherty MP, Lopes JRS, Almeida RPP (2010) Vector within-host feeding preference mediates transmission of a heterogeneously distributed pathogen. Ecol Entomol 35:360366. https://doi.org/10.1111/j.1365-2311.2010.01189.x

De Lima JEO, Miranda VS, Hartung JS, et al (1998) Coffee leaf scorch bacterium: Axenic culture, pathogenicity, and comparison with Xylella fastidiosa of citrus. Plant Dis 82:9497. https://doi.org/10.1094/PDIS.1998.82.1.94

de Souza AA, Muranaka LS, Takita MA, et al (2018) Patente (11) PI 1101176-9 B1

de Souza AA, Takita, M A, Coletta-Filho HD, et al (2003) Analysis of gene expression in two growth states of Xylella fastidiosa and its relationship with pathogenicity. Mol PlantMicrobe Interact 16:867-875. https://doi.org/10.1094/MPMI.2003.16.10.867

de Souza AA, Takita MA, Coletta-Filho HD, et al (2004) Gene expression profile of the plant pathogen Xylella fastidiosa during biofilm formation in vitro. FEMS Microbiol Lett 237:341-353. https://doi.org/10.1016/j.femsle.2004.06.055

de Souza AA, Takita MA, Coletta-Filho HD, et al (2007) Comparative analysis of differentially expressd sequence tags of sweet orange and mandarin infected with Xylella fastidiosa . Genet Mol Biol 30:965-971. https://doi.org/10.1590/s1415-47572007000500024

de Souza AA, Takita MA, Pereira EO, et al (2005) Expression of pathogenicity-related genes of Xylella fastidiosa in vitro and in planta. Curr Microbiol 50:223-228. https://doi.org/10.1007/s00284-004-4447-8

Del Cid C, Krugner R, Zeilinger AR, et al (2018) Plant water wtress and wector feeding preference mediate transmission efficiency of a plant pathogen. Environ Entomol 47:1471-1478. https://doi.org/10.1093/ee/nvy136

Dongiovanni C, Altamura G, Di Carolo M, et al (2018) Evaluation of efficacy of different insecticides against Philaenus spumarius L., vector of Xylella fastidiosa in olive orchards in southern Italy, 2015-17. Arthropod Manag Tests 43:1-4. https://doi.org/10.1093/amt/tsy034

EPPO (2018) PM 7/24 (3) Xylella fastidiosa . Eur Mediterr Plant Prot Organ 48:175-218. https://doi.org/10.1111/epp.12469

Esteves MB, Kleina HT, Sales TM, et al (2019) Transmission efficiency of Xylella fastidiosa subsp. pauca sequence types by sharpshooter vectors after in vitro acquisition. Phytopathology 109:286-293. https://doi.org/10.1094/PHYTO-07-18-0254-FI

Esteves MB, Kleina HT, Sales TM, Lopes JRS (2020) Selection of host plants for vector transmission assays of citrus variegated chlorosis strains of Xylella fastidiosa subsp. pauca. Eur Mediterr Plant Prot 
Fereres A, Moreno A (2009) Behavioural aspects influencing plant virus transmission by homopteran insects. Virus Res 141:158-168. https://doi.org/10.1016/j.virusres.2008.10.020

French JW, Kitajima EW (1978) Occurrence of plum leaf scald in Brazil and Paraguay [Rickettsialike bacteria]. Plant Dis Report 62:1033-1038

Fundecitrus (2019) Levantamento da incidência das doenças dos citros: Greening, cvc e cancro cítrico no cinturão citrícola de são paulo e triângulo/sudoeste Mineiro. https://www.fundecitrus.com.br/pdf/levantamentos/levantamento-doencas-2019.pdf

Garzo E, Moreno A, Plaza M, Fereres A (2020) Feeding behavior and virus-transmission ability of ansect vectors exposed to systemic insecticides. Plants 9:1-16. https://doi.org/10.3390/plants9070895

Goldstein GA (2006) N-acetylcysteine amide (NAC amide) for enhancing plant resistance and tolerance to environmental stress. 28

Goussain MM, Prado E, Moraes JC (2005) Effect of silicon applied to wheat plants on the biology and probing behaviour of the greenbug Schizaphis graminum (Rond.) (Hemiptera: Aphididae). Neotrop Entomol 34:807-813. https://doi.org/10.1590/s1519$566 \times 2005000500013$

Havaux M (1998) Carotenoids as membrane stabilizers in chloroplasts. Trends Plant Sci 3:147151. https://doi.org/10.1016/S1360-1385(98)01200-X

Hill BL, Purcell AH (1995a) Acquisition and retetion of Xylella fastidiosa by an efficient vector, Graphocephala atropunctata . Phytopathology 85:209-212

Hill BL, Purcell AH (1995b) Multiplication and movement of Xylella fastidiosa within grapevine and four other plants. Phytopathology 85:1368-1372. https://doi.org/10.1094/Phyto-85-1368

Hill BL, Purcell AM (1997) Populations of Xylella fastidiosa in plants required for transmission by an efficient vector. Phytopathology 87:1197-1201. https://doi.org/10.1094/PHYTO.1997.87.12.1197

Hoagland DR, Arnon DI (1950) The water culture method for growing plants without soil. Calif Agric Exp Stn 347

Hopkins DL, Purcell AH (2002) Xylella fastidiosa : Cause of Pierce's Disease of Grapevine and other emergent diseases. Plant Dis 86:1056-1066

Hoyle BD, Costerton JW (1991) Bacterial resistance to antibiotics: The role of biofilms. In: Progress in Drug Research 37. pp 91-105

Ionescu M, Zaini PA, Baccari C, et al (2014) Xylella fastidiosa outer membrane vesicles modulate plant colonization by blocking attachment to surfaces. Proc Natl Acad Sci U S A 111:1-9. https://doi.org/10.1073/pnas.1414944111

Kelly GS (1998) Clinical Applications of N-acetylcysteine. Altern Med Rev 3:114-127

Killiny N, Almeida RPP (2009a) Host structural carbohydrate induces vector transmission of a bacterial plant pathogen. Proc Natl Acad Sci U S A 106:22416-22420. https://doi.org/10.1073/pnas.0908562106

Killiny N, Almeida RPP (2009b) Xylella fastidiosa afimbrial adhesins mediate cell transmission to plants by leafhopper vectors. Appl Environ Microbiol 75:521-528. https://doi.org/10.1128/AEM.01921-08 
Krivanek AF, Walker MA (2005) Vitis resistance to Pierce's disease is characterized by differential Xylella fastidiosa populations in stems and leaves. Phytopathology 95:44-52. https://doi.org/10.1094/PHYTO-95-0044

Laranjeira FF, Pompeu Jr. J (2002) Comportamento de quinze cultivares de laranja-doce afetadas pela Clorose variegada dos citros. Laranja 23:401-411

Li W, Teixeira DC, Hartung JS, et al (2013) Development and systematic validation of qPCR assays for rapid and reliable differentiation of Xylella fastidiosa strains causing citrus $\begin{array}{llll}\text { variegated } & \text { chlorosis. M } & \text { 92:79-89. }\end{array}$ https://doi.org/10.1016/j.mimet.2012.10.008

Lindow S, Newman K, Chatterjee S, et al (2014) Production of Xylella fastidiosa diffusible signal factor in transgenic grape causes pathogen confusion and reduction in se verity of pierce's disease. Mol Plant-Microbe Interact 27:244-254. https://doi.org/10.1094/MPMI07-13-0197-FI

Lopes JRS, Daugherty MP, Almeida RPP (2009) Context-dependent transmission of a generalist plant pathogen: Host species and pathogen strain mediate insect vector competence. Entomol Exp Appl 131:216-224. https://doi.org/10.1111/j.15707458.2009.00847.x

Lopes JRS, Krugner R (2016) Transmission ecology and epidemiology of the Citrus Variegated Chlorosis Strain of Xylella fastidiosa . In: Vector-Mediated Transmission of Plant Pathogens. pp 195-208

Machado EC, Quaggi JA, Lagôa AMMA, et al (1994) Trocas gasosas e relações hídricas em laranjeiras com clorose variegada dos citros. Rev Bras Fisiol Veg 6:53-57

Maluta NKP, Lopes JRS, Fiallo-Olivé E, et al (2020) Foliar spraying of tomato plants with systemic insecticides: Effects on feeding behavior, mortality and oviposition of Bemisia tabaci (Hemiptera: Aleyrodidae) and inoculation efficiency of tomato chlorosis virus. Insects 11:1-16. https://doi.org/10.3390/insects11090559

Mansfield J, Genin S, Magori S, et al (2012) Top 10 plant pathogenic bacteria in molecular plant pathology. Mol Plant Pathol 13:614-629. https://doi.org/10.1111/j.13643703.2012.00804.x

Marchese A, Bozzolasco M, Gualco L, et al (2003) Effect of fosfomycin alone and in combination with $\mathrm{N}$-acetylcysteine on E. coli biofilms. Int J Antimicrob Agents 22:95100. https://doi.org/10.1016/S0924-8579(03)00232-2

Marucci RC, Giustolin TA, Miranda MP, et al (2003) Identification of a non-host plant of Xylella fastidiosa to rear healthy sharpshooter vectors. Sci Agric 60:669-675. https://doi.org/10.1590/s0103-90162003000400010

Marucci RC, Lopes JRS, Vendramim JD, Corrente JE (2005) Influence of Xylella fastidiosa infection of citrus on host selection by leafhopper vectors. Entomol Exp Appl 117:95-103. https://doi.org/10.1111/j.1570-7458.2005.00336.x

Miranda MP, Fereres A, Appezzato-Da-Gloria B, Lopes JRS (2009) Characterization of electrical penetration graphs of Bucephalogonia xanthophis , a vector of Xylellafastidiosa in citrus. Entomol Exp Appl 130:35-46. https://doi.org/10.1111/j.15707458.2008.00794.x

Monteiro PB, Renaudin J, Jagoueix-Eveillard S, et al (2001) Catharanthus roseus , an experimental host plant for the citrus strain of Xylella fastidiosa. Plant Dis 85:246-251. https://doi.org/10.1094/PDIS.2001.85.3.246 
Muranaka LS, Giorgiano TE, Takita MA, et al (2013) N-Acetylcysteine in agriculture, a novel use for an old molecule: Focus on controlling the plant-pathogen Xylella fastidiosa.PLoS One 8:1-14. https://doi.org/10.1371/journal.pone.0072937

Murray MG, Thompson WF (1980) Rapid isolation of high molecular weight plant DNA. Nucleic Acids Res 8:4321-5

Nagy P (2013) Kinetics and mechanisms of thiol-disulfide exchange covering direct substitution and thiol oxidation-mediated pathways. Antioxidants Redox Signal 18:16231641. https://doi.org/10.1089/ars.2012.4973

Neves M. F, Trombin VG, Milan P, et al (2010) O retrato da citricultura brasileira

Newman KL, Almeida RPP, Purcell AH, Lindow SE (2003) Use of a Green Fluorescent Strain for Analysis of Xylella fastidiosa Colonization of Vitis vinifera. Appl Environ Microbiol 69:7319-7327. https://doi.org/10.1128/AEM.69.12.7319-7327.2003

Niza B, Coletta-Filho HD, Merfa M V., et al (2015) Differential colonization patterns of Xylella fastidiosa infecting citrus genotypes. Plant Pathol 64:1259-1269. https://doi.org/10.1111/ppa.12381

Oliveira AC, Vallim MA, Semighini CP, et al (2002) Quantification of Xylella fastidiosa from Citrus Trees by Real-Time Polymerase Chain Reaction Assay. Phytopathology 92:10481054. https://doi.org/10.1094/PHYTO.2002.92.10.1048

Parry MF, Neu HC (1977) Effect of N-Acetylcysteine on antibiotic activity and bacterial growth in vitro. J Clin Microbiol 5:58-61

Pereira W, Takita M, Melotto M, de Souza A (2020) Citrus reticulata CrRAP2.2 transcriptional factor shares similar functions to the Arabidopsis homolog and increases resistance to Xylella fastidiosa . Mol Plant-Microbe Interact 33:519-527. https://doi.org/10.1094/MPMI-10-19-0298-R

Picchi SC, Takita MA, Coletta-Filho HD, et al (2016) N-acetylcysteine interferes with the biofilm formation, motility and epiphytic behaviour of Xanthomonas citri subsp. citri . Plant Pathol 65:561-569. https://doi.org/10.1111/ppa.12430

Purcell AH, Finlay A (1979) Evidence for noncirculative transmission of Pierce's Disease $\begin{array}{llll}\text { Bacterium by sharpshooter leafhoppers. Phytopathology } & \text { 69:393. }\end{array}$ https://doi.org/10.1094/phyto-69-393

Purcell AH, Finlay AH, McLean DL (1979) Pierce's Disease Bacterium: Mechanism of Transmission by Leafhopper Vectors. Science (80- ) 206:839-841

Purcell AH, Saunders SR (1999) Fate of Pierce's disease strains of Xylella fastidiosa in common riparian plants in California. Plant Dis 83:825-830. https://doi.org/10.1094/PDIS.1999.83.9.825

Qiao K, Liu Q, Xia Y, Zhang S (2021) Evaluation of a Small-Molecule Compound, NAcetylcysteine, for the manegement of bacterial spot of tomato caused by copper-resistant Xanthomonas perforans. Plant Dis 105:108-113. https://doi.org/10.1094/PDIS-05-200928-RE

Ranieri E, Zitti G, Riolo P, et al (2020) Fluid dynamics in the functional foregut of xylem-sap feeding insects: A comparative study of two Xylella fastidiosa vectors. J Insect Physiol 120:1-10 
Redak RA, Purcell AH, Lopes JRS, et al (2004) The biology of xylem fluid-feeding insect vectors of Xylella fastidiosa and their relation to disease epidemiology. Annu Rev Entomol 49:243-270. https://doi.org/10.1146/annurev.ento.49.061802.123403

Roberto SR, Coutinho A, Lima JEO, et al (1996) Transmissão de Xylella fastidiosa pelas cigarrinhas Dilobopterus costalimai , Acrogonia terminalis e Oncometopia facialis em citros. Fitopatol Bras 21:517-518

Roberto SR, Farias PRS, Bergamin Filho A (2002) Geostatistical analysis of spatial dynamics of Citrus Variegated Chlorosis. Fitopatol Bras 27:599-604

Sandanayaka WRM, Charles JG, Froud KJ (2017a) Potential use of electrical penetration graph (EPG) technology for biosecurity incursion response decision making. New Zeal Plant Prot 70:1-15. https://doi.org/10.30843/nzpp.2017.70.18

Sandanayaka WRM, Jia Y, Charles JG (2013) EPG technique as a tool to reveal host plant acceptance by xylem sap-feeding insects. J Appl Entomol 137:519-529. https://doi.org/10.1111/jen.12025

Sandanayaka WRM, Nielsen M, Davis VA, Butler RC (2017b) Do spittlebugs feed on grape? Assessing transmission potential for Xylella fastidiosa. New Zeal Plant Prot 70:31-37. https://doi.org/10.30843/nzpp.2017.70.23

Saponari M, Loconsole G, Cornara D, et al (2014) Infectivity and Transmission of Xylella fastidiosa by Philaenus spumarius ( Hemiptera: Aphrophoridae ) in Apulia, Italy. J Econ Entomol 107:1316-1319

Secex (2020) AGROSTAT - Estatísticas de comércio exterior do agronegócio brasileiro. http://indicadores.agricultura.gov.br/agrostat/index.htm

Simpson AJG, Reinach FC, Arruda P, et al (2000) The complete genome sequence of the plant pathogen Xylella fastidiosa . Nature 406:152-156. https://doi.org/10.1042/bst028a102b

Ślesak I, Libik M, Karpinska B, et al (2007) The role of hydrogen peroxide in regulation of plant metabolism and cellular signalling in response to environmental stresses. Acta Biochim Pol 54:39-50. https://doi.org/10.18388/abp.2007_3267

Swallow WH (1985) Group testing for estimating infection rates and probabilities of disease transmission. Phytopathology 75:882. https://doi.org/10.1094/phyto-75-882

Tjallingii WF (1985) Electrical nature of recorded signals during stylet penetration by aphids. Entomol Exp Appl 38:177-186. https://doi.org/10.1111/j.1570-7458.1985.tb03516.x

Tjallingii WF (1978) Electronic recording of penetration behaviour by aphids. Entomol Exp Appl 24:521-530

Usda (2020) Citrus fruit. https://www.fas.usda.gov/commodities/citrus-fruit

Wang W, Vinocur B, Altman A (2003) Plant responses to drought, salinity and extreme temperatures: Towards genetic engineering for stress tolerance. Planta 218:1-14. https://doi.org/10.1007/s00425-003-1105-5

Wells JM, Raju BC, Hung H, et al (1987) Xylella fastidiosa gen. nov. , sp. nov: GramNegative, Xylem- Limited, Fastidious Plant Bacteria Related to Xanthomonas spp. Int J Syst Bacteriol 37:136-143

Yamamoto PT (2008) Control of insect vectors of bacterial pathogens in citrus. In: Integrated Pest Management in Citrus. pp 237-260 
Yamamoto PT, Júnior WDP, Roberto SR, et al (2002a) Controle químico da cigarrinha em citros. Laranja 23:141-154

Yamamoto PT, Roberto SR, Pria Júnior WD, et al (2002b) Transmission of Xylella fastidiosa by the sharpshooters Homalodisca ignorata, Acrogonia virescens and Molomea cincta (Hemiptera: Cicadellidae) in citrus. Summa Phytopathol 28:178-181

Zhao T, Liu Y (2010) N-acetylcysteine inhibit biofilms produced by Pseudomonas aeruginosa. BMC Microbiol 10:1-8. https://doi.org/10.1186/1471-2180-10-140 


\section{APÊNDICE}

\section{Apêndice A}

Tabela 8. Tabela de resumo das ANOVAs univariadas subsequentes a MANOVA para comportamento alimentar de $P$. spumarius em plantas de $S$. oleraceus tratadas com NAC, sem NAC, ambos em formulação granulada e com inseticida, durante $6 \mathrm{~h}$ de registro.

\begin{tabular}{|c|c|c|c|c|c|}
\hline \multicolumn{6}{|c|}{ Comparações múltiplas entre os tratamentos } \\
\hline \multirow[b]{2}{*}{ Variáveis não sequenciais } & \multirow{2}{*}{\multicolumn{2}{|c|}{ Tratamentos }} & \multirow[b]{2}{*}{$\mathrm{p}$} & \multicolumn{2}{|c|}{ Intervalo de confiança } \\
\hline & & & & Limite & Limite \\
\hline \multirow[t]{2}{*}{ NWEI ${ }^{1}$ np } & \multirow[t]{2}{*}{ NAC } & sem NAC & 0,777 & $-5,207$ & 2,916 \\
\hline & & Inseticida & 0,834 & $-3,189$ & 5,189 \\
\hline \multirow[t]{2}{*}{ NWEI C } & \multirow[t]{2}{*}{ NAC } & sem NAC & 0,994 & $-5,152$ & 5,640 \\
\hline & & Inseticida & 0,058 & $-0,156$ & 10,975 \\
\hline \multirow[t]{2}{*}{ NWEI Xc } & \multirow[t]{2}{*}{ NAC } & sem NAC & 0,678 & $-0,612$ & 1,274 \\
\hline & & Inseticida & $\mathbf{0 , 0 0 0}$ & 1,027 & 2,973 \\
\hline \multirow[t]{2}{*}{ NWEI Xi } & \multirow[t]{2}{*}{ NAC } & sem NAC & $\overline{0,051}$ & 0,110 & 5,788 \\
\hline & & Inseticida & 0,000 & 3,572 & 9,428 \\
\hline \multirow[t]{2}{*}{ NWEI N } & \multirow[t]{2}{*}{ NAC } & sem NAC & $\overline{0,383}$ & $-6,293$ & 1,806 \\
\hline & & Inseticida & $\underline{0,034}$ & 0,278 & 8,631 \\
\hline \multirow[t]{2}{*}{ NWEI R } & \multirow[t]{2}{*}{ NAC } & sem NAC & $\overline{0,135}$ & $-0,555$ & 5,257 \\
\hline & & Inseticida & $\underline{0,000}$ & 2,867 & 8,861 \\
\hline \multirow[t]{2}{*}{$\mathrm{WDI}^{2} \mathrm{np}$} & \multirow[t]{2}{*}{ NAC } & sem NAC & $\overline{0,363}$ & $-78,708$ & 21,563 \\
\hline & & Inseticida & $\underline{\mathbf{0 , 0 0 0}}$ & $-273,062$ & $-169,640$ \\
\hline \multirow[t]{2}{*}{ WDI C } & \multirow[t]{2}{*}{ NAC } & sem NAC & $\overline{0,697}$ & $-8,807$ & 17,784 \\
\hline & & Inseticida & 0,093 & $-1,593$ & 25,834 \\
\hline \multirow[t]{2}{*}{ WDI Xc } & \multirow[t]{2}{*}{ NAC } & sem NAC & 0,908 & $-1,328$ & 1,888 \\
\hline & & Inseticida & 0,097 & $-0,204$ & 3,113 \\
\hline WDI Xi & NAC & sem NAC & 0,720 & $-33,349$ & 65,033 \\
\hline & & Inseticida & $\underline{0,000}$ & 73,453 & 174,926 \\
\hline WDI N & NAC & sem NAC & $\overline{0,152}$ & $-2,746$ & 0,333 \\
\hline & & Inseticida & 0,082 & $-0,144$ & 3,032 \\
\hline WDI R & NAC & sem NAC & 0,906 & $-37,260$ & 53,184 \\
\hline & & Inseticida & $\underline{0,000}$ & 36,944 & 130,230 \\
\hline Número de provas & NAC & sem NAC & $\overline{0,755}$ & $-5,186$ & 2,807 \\
\hline & & Inseticida & 0,641 & $-2,577$ & 5,668 \\
\hline Número de provas que atingiram $\mathrm{Xi}$ & NAC & sem NAC & 0,949 & $-0,782$ & 0,604 \\
\hline & & Inseticida & $\underline{\mathbf{0 , 0 0 0}}$ & 0,695 & 2,124 \\
\hline Número de provas que atingiram $\mathrm{Xi}>10 \mathrm{~min}$ & NAC & sem NAC & $\overline{0,930}$ & $-0,519$ & 0,705 \\
\hline & & Inseticida & $\underline{\mathbf{0 , 0 0 0}}$ & 0,460 & 1,722 \\
\hline Variáveis sequenciais & & & & & \\
\hline Tempo da primeira Xc do início do EPG & NAC & sem NAC & 0,993 & $-9,978$ & 10,934 \\
\hline & & Inseticida & 0,100 & $-1,404$ & 20,165 \\
\hline Tempo da primeira Xi do início do EPG & NAC & sem NAC & 0,993 & $-11,748$ & 10,694 \\
\hline & & Inseticida & 0,152 & $-2,496$ & 20,651 \\
\hline Tempo do começo da prova à primeira Xc & NAC & sem NAC & 0,595 & $-3,469$ & 8,201 \\
\hline & & Inseticida & 0,088 & $-0,636$ & 11,401 \\
\hline Tempo do começo da prova à primeira $\mathrm{Xi}$ & NAC & sem NAC & 0,886 & $-5,561$ & 8,250 \\
\hline & & Inseticida & 0,210 & $-2,060$ & 12,185 \\
\hline Tempo desde o começo do EPG à primeira $\mathrm{Xi}>10$ & NAC & sem NAC & 0,920 & $-54,553$ & 39,355 \\
\hline $\min$ & & Inseticida & 0,117 & $-7,789$ & 89,070 \\
\hline Tempo desde o começo da prova à primeira & NAC & sem NAC & 0,936 & $-51,735$ & 38,669 \\
\hline $\mathrm{Xi}>10 \mathrm{~min}$ & & Inseticida & 0,152 & $-10,046$ & 83,198 \\
\hline
\end{tabular}

${ }^{1}$ NWEI: número de ondas produzida por insetos; ${ }^{2}$ WDI: duração de onda (min) por inseto (Backus et al. 2007) 